RENAN COLLANTES CANDIA

UMA CONTRIBUIÇÃO AO ESTUDO DE ACIDENTES FATAIS POR QUEDA DE ROCHAS: O CASO DA MINERAÇÃO PERUANA 

RENAN COLLANTES CANDIA

\section{UMA CONTRIBUIÇÃO AO ESTUDO DE ACIDENTES FATAIS POR QUEDA DE ROCHAS: O CASO DA MINERAÇÃO PERUANA}

Tese apresentada à Escola Politécnica da Universidade de São Paulo para obtenção do título de Doutor em Engenharia 


\section{UMA CONTRIBUIÇÃO AO ESTUDO DE ACIDENTES FATAIS POR QUEDA DE ROCHAS: O CASO DA MINERAÇÃO PERUANA}

Tese apresentada à Escola Politécnica da Universidade de São Paulo para obtenção do título de Doutor em Engenharia

Área de concentração: Engenharia Mineral.

Orientador: Prof. Dr. Wilson Siguemasa Iramina 
Este exemplar foi revisado e alterado em relação à versão original, sob responsabilidade única do autor e com a anuência de seu orientador.

São Paulo, ....... de setembro de 2011.

Assinatura do autor

Assinatura do orientador

Candia, Renan Collantes

Uma contribuição ao estudo de acidentes fatais por queda de

rochas: o caso da mineração peruana / R.C. Candia. -- ed.rev. -São Paulo, 2011.

$139 \mathrm{p}$.

Tese (Doutorado) - Escola Politécnica da Universidade de São Paulo. Departamento de Engenharia de Minas e de Petróleo.

1. Mineração subterrânea 2. Segurança em mineração 3. Acidentes de trabalho I. Universidade de São Paulo. Escola Politécnica. Departamento de Engenharia de Minas e de Petróleo II. t. 


\section{DEDICATÓRIA}

Este trabalho está dedicado a meus pais e irmãos, pelo permanente apoio concedido durante estes anos. A Margareth e Ildézia, pela compreensão e permanente estímulo. 


\section{AGRADECIMENTOS}

À CAPES por viabilizar a realização deste trabalho, por intermédio da concessão da bolsa de auxilio à pesquisa.

Ao Departamento de Engenharia de Minas e Petróleo da Escola Politécnica da Universidade de São Paulo, por me acolher durante esses anos de estudo.

Ao Professor Prof. Dr. Wildor Theodoro Hennies, pela orientação durante a primeira etapa desta pesquisa, pelo estimulo e amizade.

Ao Prof. Dr. Wilson Siguemasa Iramina, pela orientação durante a segunda etapa desta pesquisa.

À "Oficina de Fiscalización Minera del Organismo Superior de la Inversión en Energia y Mineria del Perú (OSINERGMIN), especialmente ao Engenheiro de Minas Santos Chavez, pela concessão do registro de acidentes fatais utilizado para o desenvolvimento deste trabalho.

Ao "Ministério de energia y Minas del Peru", especialmente a Jose Matos, pelo apoio recebido e pelo intercambio de idéias durante a visita feita a Lima.

Ao Engenheiro Javier Solis Lastra, professor da "Pontifícia Universidad Católica del Perú", pelo apoio oferecido durante as visitas a Lima.

Aos Professores Dr. Ildeberto Muniz de Almeida e Rodolfo Andrade de Gouveia Vilela, pelas recomendações e sugestões de materiais bibliográficos.

Aos Engenheiros de Minas Percy Martel Moreno e Hugo Porras Sanchez, pelo apoio dado durante as visitas à mina Condestable.

A minha filha Margareth, pelos anos de ausência durante esses anos de estudo.

A todos os amigos e familiares que direta e indiretamente contribuíram para o desenvolvimento deste trabalho. 


\section{RESUMO}

A dependência de países em vias de desenvolvimento com relação às indústrias primárias como a mineração é evidente. $\mathrm{Na}$ economia peruana, aproximadamente, $6 \%$ do PIB e mais de $50 \%$ das exportações são provenientes desta atividade econômica, destacando sua posição competitiva no cenário mundial. A importância desta atividade aparece, também, quando o assunto em questão é a segurança do trabalho. Assim, embora nos últimos anos tenha-se percebido uma diminuição no número de acidentes na mineração peruana, a taxa de mortalidade ainda é alta quando comparada com outros países de tradição mineira, especialmente os mais desenvolvidos. No Peru, oficialmente, as causas fundamentais para a ocorrência de acidentes são atribuídas aos fatores pessoais e de trabalho, assim como às condições e aos atos inseguros. Nesse contexto, a identificação dessas causas, visando à proposta de soluções efetivas para melhor gerenciar os sistemas de segurança e de saúde na indústria da mineração, é muito importante. Esta tese estuda os acidentes por queda de rochas em minas subterrâneas do Peru. Para tal foi utilizado como fonte de informação primária o registro de acidentes fatais de 2007 em minas de médio e grande porte. Esse registro foi concedido pela "Oficina de Fiscalización Minera del Organismo Superior de la Inversión en Energía y Minería del Peru" (OSINERGMIN), órgão pertencente ao "Ministério de Energía y Minas del Perú" (MEM). O estudo mostra que a maioria dos acidentes fatais são provocados pela queda de rochas em escavações subterrâneas; assim, no período em estudo, este tipo de acidente representou $29,41 \%$ dos eventos. O estudo das características pessoais das vítimas mostra ainda que trabalhadores que desenvolvem funções de perfuração, preparação e instalação de suporte pós-desmonte tanto em frentes de lavra de produção quanto em escavações de desenvolvimento morrem por causa de traumatismos múltiplos e encefalo-cranianos severos. A maioria das vítimas pertencia a empresas mineiras terceirizadas. A partir do estudo das características pessoais das vítimas e utilizando os Métodos de Regressão Logística (MRL), propõe-se um modelo matemático para determinar a chance de se sofrer acidente por queda de rochas, em relação a outros tipos de acidentes. Os resultados mostram que trabalhadores que desempenham a função de ajudante, bem como trabalhadores com experiência de mais de três anos têm menos chance de sofrer acidentes por queda de rochas. Finalmente, foram identificados as causas fundamentais e imediatas dos acidentes estudados. Entre os fatores pessoais e de trabalho destacam-se o excesso de confiança e a supervisão deficiente como sendo as principais causas deste tipo de acidente. O estudo mostra também que o descumprimento de procedimentos operacionais e a presença de rochas soltas nas escavações constituem os principais tipos de atos e condições inseguras, respectivamente.

Palavras-Chave: Acidentes de trabalho. Queda de rochas. Fatores causais. Mineração peruana. Métodos de Regressão Logística. 


\begin{abstract}
There are several evidences that developing countries depend on primary industries like mining. In fact about 6\% of the Peruvian Gross Domestic Product (GDP) and $50 \%$ of exports are provided by mining. As well as in economy, mining has been strongly affecting the statistics concerning the safety in the workplace. Thus, although in recent years there was a decrease in the number of mining accidents in Peruvian mining, the fatality rate is still high compared to other traditional mining countries, especially the developed ones. In Peru, according to official statements, the primary causes of the accidents are attributed to personal and work factors, as well as unsafe conditions and acts. Based on this information, the identification of these causes, aiming the proposal of effective solutions to enhance safety and health management systems in mining becomes a very important issue. This thesis has studied the accidents caused by the fall of rocks in Peruvian underground mines, using as the main source of information about the fatalities occurred in 2007 in medium and large mines. This information was provided by the "Oficina de Fiscalización Minera del Organismo Superior de la Inversión en Energía y Minería del Perú (OSINERGMIN) ", an agency under administration of the Ministry of Energy and Mines of Peru (MEM)." The study shows that the majority of fatal accidents are caused by rock falls in underground excavations, and also that rock falls have accounted for $29.41 \%$ of all events during the studied period. Studying the personal characteristics of the victims also showed that the main victims are workers when they were developing drilling and preparation and installation of rock support activities in development areas as well as in production and excavations areas. The data showed that the majority died by severe multiple and cranial traumas and most of them were third part workers. From the study of the personal characteristics of victims and using the Methods of Logistic Regression (MLR), this research proposes a mathematical model to determine the chance of suffering an accident by rocks falls compared to other types of accidents. Also, the selected model showed that, from the statistical point of view, the experience in mining is the most representative variable and those workers having most of hree years of experience have lower probability to suffer injuries by rock falls. Finally, the root and immediate causes of accidents were identified. Among personal and working factors the overconfidence and lack of supervision were respectively highlighted. The study also showed that non-complying operational procedures and the presence of loose rocks during the excavations are respectively the main types of unsafe acts and conditions.
\end{abstract}

Keywords: Occupational accidents. Rock fall. Factors causes. Peruvian mining. Logistic Regression Methods. 


\section{LISTA DE FIGURAS}

Figura 2.1 Diagrama simplificado de materiais e métodos utilizados no desenvolvimento da pesquisa...

Figura 3.1 Valores exportados de produtos mineiros FOB e número de acidentes fatais.................................................. 28

Figura $3.2 \quad$ Teoria dos dominós............................................ 34

Figura 3.3 Modelo de acidente organizacional ......................................... 37

Figura 3.4 Classificação de métodos de lavra subterrânea.............................. 42

Figura 3.5 Queda de rochas sobre a caçamba do scooptram........................ 43

Figura 3.6 Instabilidades estruturalmente controladas em escavações subterrâneas...................................................................... 48

Figura 3.7 Instabilidades estruturalmente controladas em escavações subterrâneas........................................................................... 49

Figura $3.8 \quad$ Estrutura organizacional tradicional........................................ 52

Figura $3.9 \quad$ Estrutura organizacional moderna ........................................... 53

Figura 3.10 Queda de rochas em escavações subterrâneas............................ 64

Figura 3.11 Retirada manual de rocha solta ............................................... 66

Figura 3.12 Retirada mecanizada de rocha solta com scaler............................ 67

Figura 4.1 Evolução da taxa de mortalidade na mineração peruana de 2000

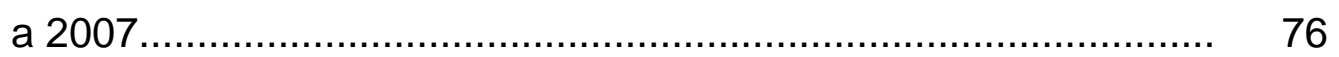

Figura 4.2 Comparativo do número de trabalhadores na mineração metálica e não metálica entre USA e Peru............................................. 76

Figura 4.3 Comparativo do número vítimas fatais na mineração metálica e não metálica entre USA e Peru de 2002 a 2007........................... 77

Figura 4.4 Comparativo da taxa de mortalidade na mineração metálica e não metálica entre USA e Peru de 2002 a 2007.

Figura 4.5 Faixa etária de vítimas fatais em acidentes por queda de rochas no ano de 2007

Figura 4.6 Distribuição de frequências da experiência em mineração das vítimas fatais em acidentes por queda de rochas em 2007.

Figura 4.7 Distribuição de frequências de tempo de serviço de vítimas fatais em acidentes por queda de rochas no ano 2007. 
Figura 4.8 Diagrama de dispersão entre a idade e a experiência em mineração de vítimas de acidentes por queda de rochas no ano 2007

Figura 4.9 Diagrama de dispersão entre a idade e o tempo de serviço de vítimas de acidentes por queda de rochas em 2007.

Figura 4.10 Diagrama de dispersão entre experiência em mineração e o tempo de serviço de vítimas de acidentes por queda de rochas em 2007

Figura 4.11 Frequência relativa da escolaridade das vítimas fatais de acidentes por queda de rochas no ano de 2007

Figura 4.12 Freqüência relativa de vítimas fatais em acidentes por queda de rochas segundo a ocupação no ano 2007

Figura 4.13 Freqüência relativa de vítimas fatais em acidentes por queda de rochas segundo vínculo empregatício no ano 2007. 88

Figura 4.14 Freqüência relativa de vítimas fatais segundo o tipo de lesão. 89 


\section{LISTA DE TABELAS}

Tabela 3.1 Exportações peruanas FOB por grupo de produtos em 2007 (milhões de US\$).....

Tabela 3.2 Principais reservas peruanas provadas e prováveis de minérios em 2007. 27

Tabela 3.3 Posição de produção mineral do Peru no ano 2007.

Tabela 3.4 Valores exportados de produtos mineiros FOB do ano 2000 a 2007

Tabela 3.5 Causas de instabilidades em escavações subterrâneas condicionadas estruturalmente.

Tabela 3.6 Causas de instabilidades em escavações subterrâneas condicionadas pelo estado de tensões

Tabela 3.7 Diferença de enfoques de gestão de segurança entre uma organização tradicional e uma organização moderna no Peru........ 53

Tabela 3.8 Funções dos gestores e trabalhadores na gestão de segurança... 56

Tabela 4.1 Acidentes de trabalho indenizados pelos sistemas de previdência social pública e privada no Peru por tipo de atividade económica

Tabela 4.2 Número de trabalhadores, acidentes e vítimas fatais em acidentes de mineração desde o ano 2000 a 2007.

Tabela 4.3 Número de ocorrências com óbito na mineração do Peru segundo o tipo de acidente.

Tabela 4.4 Número de vítimas fatais na mineração do Peru segundo o tipo de acidente

Tabela 4.5 Número de acidentes fatais na grande e mediana mineração em 2007.

Tabela 4.6 Correlação entre idade, tempo de serviço e experiência em mineração das vítimas de acidentes por queda de rochas em 2007

Tabela 4.7 Recodificação das variáveis para seu uso na geração do MRL.....

Tabela 4.8 Matriz de entrada recodificada para a geração do modelo de regressão logística.

Tabela 4.9 Avaliação de risco de sofrer acidente por queda de rocha em 
função as variáveis estatisticamente significativas.................... 95

Tabela 4.10 Odds ratio ou razões de chance entre os diferentes perfis............ 96

Tabela 4.11 Fatores pessoais identificados na ocorrência de acidentes por queda de rochas........................................................ 97

Tabela 4.12 Fatores de trabalho identificados na ocorrência de acidentes por queda de rochas............................................................ 99

Tabela 4.13 Atos inseguros identificados na ocorrência de acidentes por queda de rochas............................................................. 102

Tabela 4.14 Condições inseguras identificadas na ocorrência de acidentes por queda de rochas. 


\section{LISTA DE ABREVIATURAS E SIGLAS}

OSINERGMIN Oficina de Fiscalización Minera del Organismo Superior de la Inversión en Energia y Mineria del Perú

MEM Ministério de Energia y Minas del Perú

MRL Métodos de Regressão Logística

ILO International Labour Organization

$\mathrm{PIB}$ Produto Interno Bruto

PECE Programa de Educação Continuada em Engenharia

UNESP Universidade Estadual de São Paulo

USP Universidade de São Paulo

SPSS

Statistical Package for the Social Science

IME Instituto de Matemática e Estatística

FOB Free on Board

OHSAS Occupational Health and Safety Assesment Series ABNT Associação Brasileira de Normas Técnicas

CLT Consolidação das Leis do Trabalho

AET Análise Ergonômica do Trabalho

SST Segurança e Saúde no Trabalho

ISO International Organization for Standardization

SSO Segurança e Saúde Ocupacional MSHA Mine Safety and Health Administration $\mathrm{NIOSH}$ National Institute of Occupational Safety and Health MSA Mine Safety Appliances

$\mathrm{HHT}$ Horas Homem Trabalhadas

IF Índice de Freqüência

IS Índice de Severidade

ISEM Instituto de Seguridad Minera SNMPE Sociedad Nacional de Minería Petróleo y Energía

CIP Colegio de Ingenieros del Perú

EPI Equipamentos de Proteção Individual Safety in Mines Research Advisory Committee of South Africa $\mathrm{RL}$ Regressão Logística 
IC

TM

TL

Intevalo de Confiança

Toneladas métricas

Toneladas longas 


\section{SUMÁRIO}

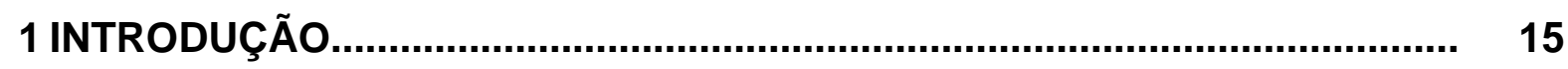

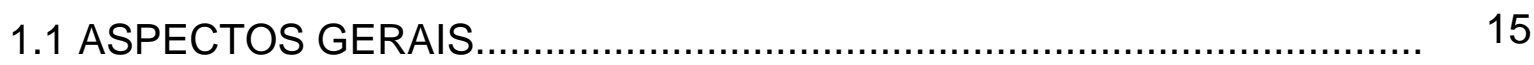

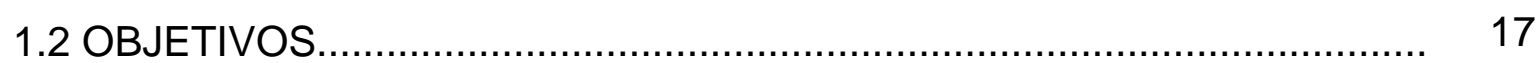

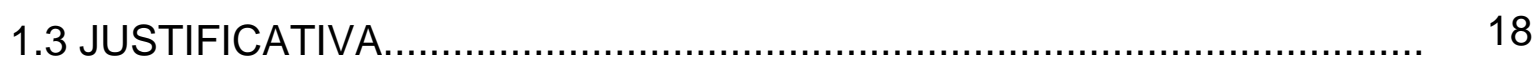

2 MATERIAIS E MÉTODOS...................................................................

3 REVISÃO BIBLIOGRÁFICA............................................................... 25

3.1 A INDÚSTRIA DA MINERAÇÃO NO PERU............................................ 25

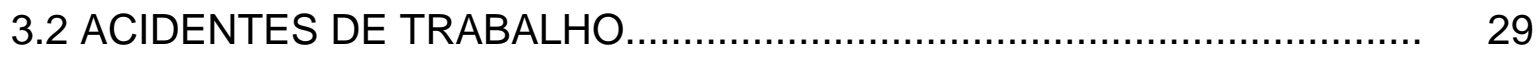

3.3 ORIGEM DOS ACIDENTES DE TRABALHO..................................... 32

3.3.1 Abordagem tradicional da origem de acidentes................................... 33

3.3.2 Abordagem comportamentalista da origem de acidentes .................... 36

3.3.3 Abordagem sistêmica da origem de acidentes.................................... 37

3.3.4 A ergonomia no estudo de acidentes de trabalho.................................. 40

3.4 ESCAVAÇÕES SUBTERRÂNEAS NA MINERAÇÃO.............................. 41

3.5 QUEDA DE ROCHAS EM ESCAVAÇÕES SUBTERRÂNEAS................. 43

3.5.1 Causas de instabilidades em escavações subterrâneas........................ 46

3.5.2 Principais tipos de instabilidade em escavações subterrâneas............... 47

3.6 GESTÃO DE SEGURANÇA E SAÚDE NA MINERAÇÃO …………........ 50

3.6.1 Enfoques da gestão de segurança nas organizações da industria da

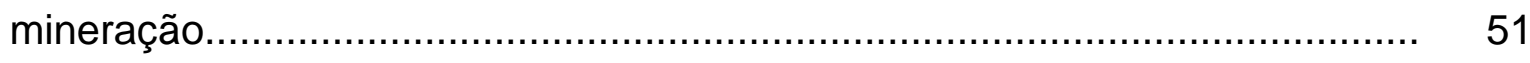

3.6.2 Papel da gerência na gestão de segurança.......................................... 54

3.6.3 Evolução da gestão de segurança na mineração peruana..................... 57

3.7 ACIDENTES DE TRABALHO NA MINERAÇÃO...................................... 59

3.8 ACIDENTES POR QUEDA DE ROCHAS NA MINERAÇÃO

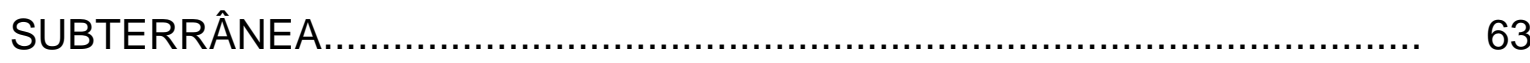


3.9 MODELAGEM MATEMÁTICA NA SAÚDE OCUPACIONAL..................... 67

3.10 MÉTODOS DE REGRESÃO LOGÍSTICA............................... 69

4 ESTUDO DE ACIDENTES POR QUEDA DE ROCHAS NA MINERAÇÃO

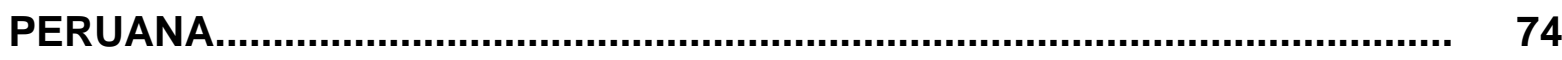

4.1 DESEMPENHO DA SEGURANÇA NA MINERAÇÃO PERUANA............. 74

4.2 CARACTERÍSTICAS PESSOAIS DAS VÍTIMAS FATAIS EM ACIDENTES POR QUEDA DE ROCHAS........................................... 81

4.3 MODELAGEM DO RISCO DE ACIDENTABILIDADE POR QUEDA DE

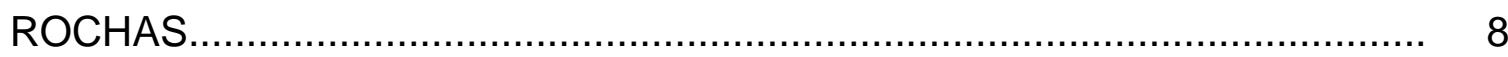

4.4 ANÁLISE DE FATORES CAUSAIS NOS ACIDENTES POR QUEDA DE ROCHAS.

5 CONSIDERAÇÕES ADICIONAIS NA ANÁLISE DE ACIDENTES POR QUEDA DE ROÇAS NA MINERAÇÃO PERUANA.

6 CONCLUSÕES

REFERÊNCIAS BIBLIOGRÁFICAS........................................................ 113

ANEXO A - MODELO DE RELATÓRIO DE ACIDENTE ELABORADO PELO MINISTÉRIO DE ENERGIA E MINAS DO PERU........................................... 120

ANEXO B - MINAS E PROJETOS NO PERU.............................................. 122

APÊNDICE A - PRIMEIRA CARTA DE SOLICITAÇÃO DE INFORMAÇÃO A

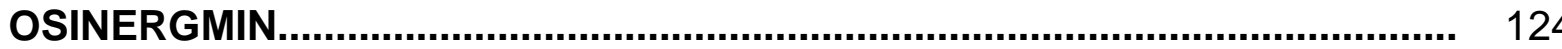

APÊNDICE B - TABELA DE ACIDENTES FATAIS NA MINERAÇÃO PERUANA EM 2007

APÊNDICE C - SEGUNDA CARTA DE SOLICITAÇÃO DE INFORMAÇÃO A OSINERGMIN

APÊNDICE D - ESTIMATIVA DE COEFICIENTES DO MODELO DE REGRESÃO LOGÍSTICA.

APÊNDICE E - APLICAÇÃO DE ENTREVISTA NA MINA CONDESTABLE... 128 


\section{INTRODUÇÃO}

\subsection{ASPECTOS GERAIS}

A mineração constitui uma das atividades mais antigas da humanidade, pois o homem ao longo do seu desenvolvimento sempre utilizou algum elemento da crosta terrestre, denominando inclusive as eras históricas a partir do material mais utilizado na época como a idade da pedra, do ferro, entre outras. Não podemos imaginar o mundo de hoje prescindindo da mineração, que possibilitou o desenvolvimento da nossa espécie, permitindo, assim, importantes avanços científicos e tecnológicos.

Apesar da reconhecida importância da mineração para o desenvolvimento humano, esta tem sido objeto de questionamentos por parte de órgãos governamentais e não governamentais devido às possíveis agressões ambientais assim como aos aspectos relacionados à saúde e à segurança dos trabalhadores e das populações circunvizinhas aos empreendimentos.

A lavra e o beneficiamento de recursos minerais estão associados aos vários riscos ocupacionais no mundo todo; e por isso a atividade da mineração, embora esteja num processo contínuo de mecanização, ainda é reconhecida como uma das mais perigosas. Os trabalhadores na mineração estão expostos a riscos durante o desempenho de atividades profissionais, assim, os acidentes podem ser causados por diversos agentes encontrados nos ambientes e processos de trabalho.

A lavra de minas, especialmente a subterrânea, se caracteriza por ser desenvolvida em condições geológicas adversas marcadas principalmente pela heterogeneidade e anisotropia do maciço rochoso, cujo conhecimento na prática sempre será limitado. A falta de espaço, a ausência de luz, a existência de atmosferas perigosas, entre outros fatores, dificultam ainda mais o desenvolvimento de atividades, provocando acidentes e doenças ocupacionais.

$\mathrm{Na}$ atualidade, mesmo quando tenham sido feitas melhorias significativas nos projetos de escavações, na concepção de equipamentos empregados, na mudança de atitudes para a prevenção de acidentes, entre outros, a proporção de acidentes de trabalho quando comparada com outro tipo de atividades industriais ainda é alta. 
A queda de rochas e as explosões em escavações subterrâneas são reconhecidas como duas das principais causas de acidentes na mineração subterrânea. Na maioria dos países com tradição mineira a queda de rochas constitui a principal causa de acidentes de trabalho. Assim, no Peru a queda de rochas representa aproximadamente $37 \%$ dos acidentes fatais (PERU, 2008a).

Outro aspecto importante a ressaltar é o fato de que os acidentes de trabalho na mineração geralmente têm consequências graves do ponto de vista das perdas geradas. Os acidentes em minas subterrâneas, igualmente aos acidentes de aviação e navegação, são caracterizados pela baixa possibilidade de sobrevivência ou ainda pela elevada taxa de mortalidade ${ }^{1}$.

Em países como a China, os acidentes de mineração, especialmente os provocados pela explosão em minas de carvão, são os que mais vítimas causam, sendo comparados com aqueles causados pelo rompimento de barragens, a queda de aviões comerciais, o descarrilamento de trens, os desastres marinhos, incêndios e acidentes na indústria química, os quais se caracterizam pela alta mortalidade, pelo baixo número de sobreviventes, e pela relativa baixa taxa de resgate com sucesso (ZHANGTAO, 2010).

Nesse contexto, o estudo dos acidentes, por meio da análise de riscos, pode estabelecer a identificação e a mensuração dos mesmos, oferecendo a possibilidade de sua prevenção através da melhor organização e planejamento dos sistemas produtivos, o que por sua vez se traduz na minimização das interrupções dos processos produtivos e a melhoria na qualidade dos bens e serviços produzidos, o que se traduz finalmente na maximização de lucro para as empresas.

A análise de acidentes é entendida como sendo um processo de avaliação do acidente visando identificar os fatores causais para tal. A identificação dos fatores causais em cada acidente permite inferir tendências e assim formular ações preventivas visando diminuir a ocorrência de novos acidentes o que por sua vez promove o aprendizado coletivo.

Partindo do pressuposto de que na gênese dos acidentes de trabalho participam

\footnotetext{
${ }^{1}$ Taxa de mortalidade: número de óbitos/número de empregos no setor econômico x 100.000. Para o periodo em estudo, a taxa da mortalidade na mineração peruana foi de 45,93. (Peru, 2010).
} 
vários fatores; sua identificação por parte do Sistema de Gestão de Segurança é de extrema importância. Em outro aspecto, levando em consideração que o objetivo de uma boa engenharia é a minimização de perdas nos empreendimentos projetados, ou seja, a maximização de lucros por parte da empresa, a aplicação das melhores habilidades e conhecimentos tecnológicos é necessária, garantindo a implantação e aproveitamento dos empreendimentos de forma mais segura e econômica.

Dado que é impossível imaginar a existência da humanidade sem a mineração e tendo em mente que esta atividade é considerada como uma das mais perigosas, deverão ser considerados todos os esforços necessários para a redução de acidentes de trabalho e doenças ocupacionais levando em consideração aspectos relacionados ao trabalhador, ao ambiente de trabalho, ao ambiente social e natural, à organização do trabalho e aos aspectos jurídicos visando a minimização de acidentes de trabalho.

\subsection{OBJETIVOS}

Este trabalho tem como objetivo principal propor um modelo matemático que permita estimar a probabilidade de um trabalhador sofrer acidente fatal por queda de rochas em minas subterrâneas. Isto foi feito a partir das características pessoais e de trabalho identificados nos relatórios de acidentes fatais no ano de 2007 na grande e média mineração do Peru. Para tal utilizou-se os Métodos de Regressão Logística (MRL). O trabalho ainda procura:

- Mostrar a importância da mineração peruana enquanto atividade econômica assim como causadora de acidentes de trabalho;

- Estudar os acidentes por queda de rochas na mineração subterrânea e sua importância na causalidade de acidentes fatais;

- Identificar as variáveis (características pessoais) mais relevantes na ocorrência de acidentes por queda de rochas;

- Discutir as deficiências e falhas nos Sistemas de Gestão de Segurança das empresas peruanas a partir da análise das causas imediatas e fundamentais identificadas nos relatórios de acidentes por queda de rochas do ano 2007. 


\subsection{JUSTIFICATIVA}

No cenário mundial, a questão de segurança e saúde no trabalho representa um desafio para os governos e para as organizações. Em 2001, morreram aproximadamente 350.000 trabalhadores, ou seja, aproximadamente 1.000 trabalhadores a cada dia. Ainda nesse ano, se estima que aconteceram 270 milhões de acidentes de trabalho que provocaram a ausência do trabalhador por mais de 3 dias (HAMALAINEN, 2009).

A Organização Internacional do Trabalho (ILO) tem estimado que os custos ${ }^{2}$ decorrentes de acidentes e doenças ocupacionais representam aproximadamente $4 \%$ do PIB mundial (ILO, 2003 apud HAMALAINEN, 2009). Em 2003, o PIB mundial foi da ordem de US $\$ 34 \times 10^{12}$, o que significa que nesse ano foram gastos em acidentes e doenças ocupacionais aproximadamente US $\$ 1,36 \times 10^{12}$.

Os acidentes de trabalho em sociedades modernas são onerosos devido aos recursos utilizados para cobrir os custos médicos e emergenciais, a perda de salários, os gastos administrativos ou legais, a interrupção do processo produtivo, a diminuição da qualidade de vida, entre outros. Estes custos que são embutidos nos produtos são repassados para os consumidores (RIKHARDSSON e IMPGAARD, 2004).

No aspecto social, o acidente de trabalho e a doença ocupacional são fatores que fomentam a miséria social, seja pela diminuição da renda familiar, pela incapacidade para o trabalho e mesmo pela perda de vidas; assim, a sociedade como um todo deverá se sensibilizar pelos números catastróficos e pelas consequências de ordem financeira e social que os acidentes provocam (LAPA, 2009).

A globalização da economia mundial faz com que a maioria dos países tentem tirar o maior proveito possível do aproveitamento dos seus recursos. Nesse contexto, a atividade da mineração no Peru desempenha papel importante por ser um setor que contribui significativamente para a geração de riqueza. No ano de 2007 o setor da mineração e dos hidrocarbonetos contribuiu com $5,8 \%$ e $61,8 \%$ do PIB e das exportações respectivamente; conferindo-Ihe destaque em referência a outros setores

2 Entre os custos associados aos acidentes de trabalho podem-se indicar os ressultantes dos tempo gasto em atividades relacionadas ao acidente, materiais e componentes danificados, serviços externos, previdencia social, os custos assumidos pela propria familia da vítima, pagamento de multas, rehabilitação de áreas danificadas, entre outros (RIKHARDSSON e IMPGAARD, 2004). 
econômicos (PERU, 2008a).

Os locais onde são descobertas as jazidas minerais com potencialidade de serem lavradas são caracterizados tipicamente pela pobreza, resultante do baixo investimento por parte do governo em programas econômicos e sociais. A implantação de projetos mineiros nesses locais significa a melhoria da qualidade de vida da população circunvizinha através da geração de empregos, a construção de infraestrutura, a melhoria de renda, entre outros.

No entanto, a importância da mineração se ressalta também pelo elevado número de acidentes provocados no seu exercício quando se compara com outros setores econômicos. A mineração é um dos setores em que mais acidentes de trabalho ocorrem no mundo, apresentando altas taxas de mortalidade (HUNTING e WEEKS, 1993; PEAKE e ASHWORTH, 1996; TROTTER e KOPESCHNY, 1997; GYEKYE, 2003 e GHOSH; BHATTACHERJEE e CHAU, 2004).

Segundo ILO (2010), no Peru a mineração foi a atividade que mais provocou acidentes de trabalho nos anos de 2006 e 2007 com cifras que atingiram $41 \%$ e $28 \%$ das ocorrências respectivamente, seguida pela manufatura e pela construção civil. Ainda no ano de 2007, 84\% dos acidentes fatais aconteceram na lavra subterrânea, $13 \%$ na lavra a céu aberto e $3 \%$ em atividades de beneficiamento e embarque (PERU, 2008a).

Nesse contexto, o tipo de acidente mais representativo na mineração é o provocado pela queda de rochas em escavações subterrâneas. De 2000 a 2007, aconteceram 443 acidentes fatais com um total de 499 vítimas, dos quais 163 acidentes foram por queda de rochas, resultando em 181 vítimas fatais. Isso representa aproximadamente $37 \%$ dos acidentes de trabalho, seguido pela queda de pessoas, pelo tráfego de veículos, entre outros.

Embora a queda de rochas seja a principal causa de fatalidades no Peru, seu estudo através de uma abordagem sistemática, visando a identificação dos fatores causais ainda é pouco abrangente. Nesse contexto, a identificação dos principais fatores causais pode servir para a proposta e implementação, pelas partes interessadas, de medidas de controle eficazes para reduzir este tipo de acidente e seu grau de severidade. 
A escolha do estudo abordando os acidentes por queda de rochas no Peru se justifica devido ao fato de a maioria das minas utilizarem métodos de lavra subterrânea, e de que, nos últimos anos, os acidentes por queda de rochas representarem a principal causa de acidentes de trabalho. Além disso, o autor desta tese, por ter nacionalidade peruana, sentiu-se estimulado em abordar $\mathrm{o}$ caso peruano; principalmente pela familiaridade com alguns ambientes mineiros peruanos e pela menor dificuldade em se obter dados estatísticos da mineração peruana em relação a brasileira.

Apesar de ter se considerado inicialmente a possibilidade do desenvolvimento do presente trabalho abordando o caso brasileiro, esta não foi possivel, principalmente pela dificuldade de obtenção de dados e informações necessárias para tal; no entanto, acredita-se que a metodologia empregada para o desenvolvimento do presente trabalho possa ser utilizada também para tratar o caso brasileiro. 


\section{MATERIAIS E MÉTODOS}

Para o desenvolvimento deste trabalho foi feita uma revisão bibliográfica abrangente dos tópicos referentes à segurança e saúde ocupacional na mineração, utilizando-se como fonte de informação a bibliografia existente em algumas universidades nacionais e internacionais, a qual se considerou como a mais relevante. Ainda com o intuito de ter acesso a artigos acadêmicos em revistas especializadas nacionais e internacionais foram feitas pesquisas em sites especializados.

Devido à necessidade do aprofundamento de conhecimentos referentes à área de Segurança do Trabalho, foi feita por parte do Professor Doutor Wildor Theodoro Hennies (orientador da primeira parte do trabalho) uma solicitação de concessão de bolsa ao Programa de Educação Continuada em Engenharia (PECE) da Escola Politécnica da Universidade de São Paulo para a participação do autor no curso de especialização em Engenharia de Segurança do Trabalho. Este curso foi concluído em abril de 2010.

Simultaneamente ao desenvolvimento da pesquisa, o autor participou de encontros de caráter acadêmico e cientifico em eventos nacionais e internacionais, assim como em painéis e fórums organizados por departamentos acadêmicos de universidades nacionais (UNESP - USP). Isto possibilitou a aproximação junto aos profissionais especializados da área de segurança e saúde ocupacional, o que por sua vez permitiu a discussão de temas relacionados ao assunto abordado.

O objetivo do trabalho foi fazer uma análise de acidentes fatais por queda de rochas na mineração peruana de grande e médio porte que ocorreram durante o ano 2007. Consideram-se como mineração de grande e médio porte aqueles empreendimentos que têm uma capacidade de produção e/ou beneficiamento maior do que trezentas e cinquenta (350) toneladas métricas por dia em caso de minerais metálicos; e maior do que mil e duzentas (1200) toneladas métricas por dia para minerais não metálicos como materiais de construção (PERU, 2008b).

A Informação para o desenvolvimento do presente trabalho foi gerada a partir dos relatórios dos acidentes acontecidos na grande e média mineração do Peru (Vide modelo segundo o Anexo, A), durante o ano 2007. Esta informação foi solicitada pelo 
autor em novembro de 2008 (Vide apêndice A) ao "Organismo Supervisor de la Inversión en energia y Minería" (OSINERGMIN), entidade pertencente ao "Ministerio de Energia y Minas del Peru" (MEM).

Após visita e reunião com o diretor, o Engenheiro Guillermo Shinno, no escritório do OSINERGMIN, na cidade de Lima (Peru), foi concedida ao autor a informação em janeiro de 2008, salientando-se que esta informação seria utilizada para propósitos estritamente acadêmicos. A partir dos relatórios de acidentes foi gerada uma base de dados em formato de uma planilha Excel para sua análise correspondente (Vide Apêndice B).

Para melhorar o estudo em desenvolvimento, foi feita uma segunda solicitação de informação à Osinergmin (Vide Apêndice C) procurando incrementar o número de eventos e, deste modo, dar maior suporte à pesquisa, especialmente no que diz à robustez do modelo que permitiria fazer a estimativa do risco de acidentabilidade por queda de rochas ${ }^{3}$. Esta solicitação, no entanto, não foi atendida pelas autoridades peruanas.

Ainda com o intuito de entender melhor o fenômeno de queda de rochas e suas consequências, foram feitas várias visitas a uma mina subterrânea no Peru. Estas visitas permitiram verificar "in loco" a forma como os mineiros (trabalhadores das frentes de lavra) assim como os gestores enfrentam as variabilidades das condições de trabalho; especialmente no que diz respeito à limpeza e retirada de blocos soltos em escavações subterrâneas (bater chocos), uma vez que na execução destas atividades acontecem a maioria dos acidentes por queda de rochas (vide Apêndice E).

Para o entendimento deste trabalho, os acidentes fatais são definidos como aqueles acidentes que resultaram em morte com qualquer trabalhador que no momento da sua ocorrência estava realizando trabalhos na atividade de mineração, o que quer dizer que, no que concerne à população em estudo, estão compreendidos trabalhadores da própria empresa mineira, assim como trabalhadores de empresas prestadoras de serviços especializados (empreiteiras ou terceirizadas) nas diversas

\footnotetext{
3 Uma das vantagens do uso da Regressão Logística $(R L)$ é que permite o uso de várias variáveis com relativamente poucos casos. No entanto, o tamanho da amostra necessaria depende do tipo de estudo que se realiza. Contudo, quanto maior o numero de amostras, mais robusto e confiavel será o modelo gerado (SILVA, 1995).
} 
operações de lavra, serviços auxiliares de mina assim como em atividades de beneficiamento, transporte e embarque de minerais (PERU, 2001a).

Para efeitos da análise estatística descritiva, foram utilizados como ferramentas os softwares comerciais "Statistical Package for the Social Science" SPSS ${ }^{\circledR} 15.0$ da "Statistical Product and Service Solutions"; assim como o Excel ${ }^{\circledR}$ da "Microsoft Corporation". O primeiro software foi fornecido por pesquisadores do Instituto de Matemática e Estatística (IME) da Universidade de São Paulo (USP). Os resultados obtidos com esse auxílio são mostrados basicamente em forma de tabelas e gráficos.

A partir do estudo das características pessoais das vítimas fatais (como a idade, o tempo de serviço, a experiência em mineração, a escolaridade entre outras), foi proposto um modelo matemático que determina o risco, na forma de probabilidade, de um trabalhador sofrer um acidente por queda de rochas. Esse modelo foi elaborado a partir de Métodos de Regressão Logística (MRL). Essa metodologia permitiu também estabelecer o risco relativo de sofrer um acidente por queda de rochas comparativamente a outro tipo de acidentes na mineração subterrânea.

Para o estabelecimento do modelo matemático propriamente dito, a partir da base de dados desenvolvida (Apêndice B), foi feita uma filtragem de eventos; ou seja, foram retirados todos aqueles eventos que ocorreram na mineração a céu aberto, assim como as atividades de beneficiamento, transporte e embarque de minerais. Ainda em conformidade com as restrições por parte dos MRL, foi feita uma recodificação. A partir dos dados recodificados foi estabelecida uma matriz de entrada o mesmo que constitui o input para a estimativa dos coeficientes ou parâmetros dos Modelos Matemáticos gerados (Apêndice D).

A partir da análise estatística descritiva, discutem-se as causas básicas dos acidentes (fatores pessoais, e fatores de trabalho) assim como as imediatas (atos e condições inseguras da abordagem tradicional); que são consideradas como os fatores causais para o desencadeamento dos acidentes. Finalmente são apresentadas as conclusões e considerações finais baseadas nas informações obtidas e nos estudos desenvolvidos. A Figura 2.1 mostra o diagrama simplificado da metodologia empregada no presente estudo. 
- Revisão bibliográfica;

- Participação em painéis e fórums;

- Participação em seminários e congressos no Peru.
- Participação e conclusão do curso de especialização em Engenharia de segurança do trabalho (PECE).

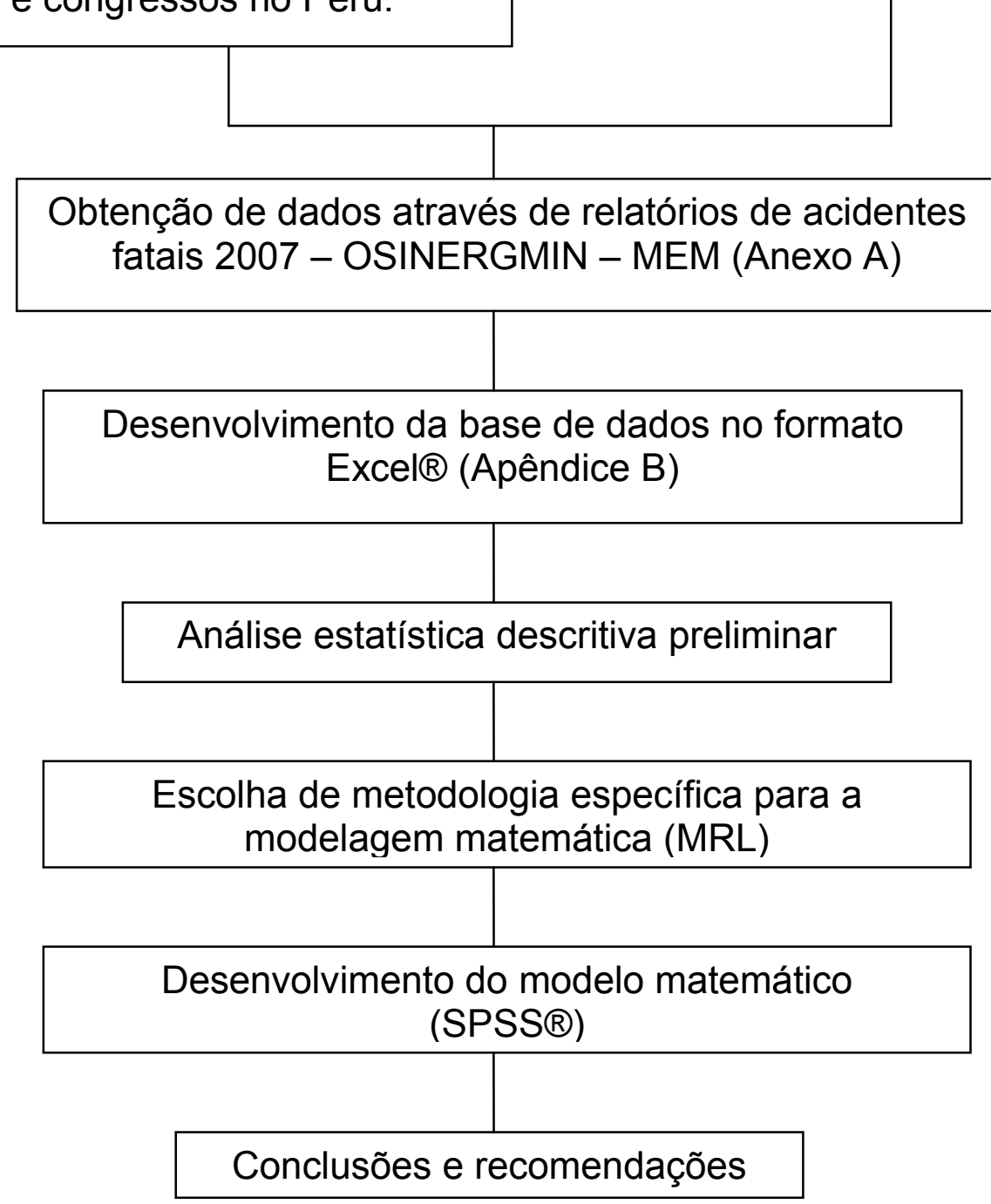

Figura 2.1 - Diagrama simplificado de materiais e métodos utilizados no desenvolvimento da pesquisa 


\section{REVISÃO BIBLIOGRÁFICA}

\subsection{A INDÚSTRIA DA MINERAÇÃO NO PERU}

A indústria da mineração historicamente foi uma das atividades mais importantes da economia peruana desde a época pré-incaica até a atualidade. Na época pré-inca, houve avanços significativos na metalurgia; conheceu-se o ouro, a prata, o cobre; desenvolveram-se ligas como o bronze, assim como utilizou-se o ferro por suas propriedades corantes na cerâmica e fabricação de têxteis (SAMAMÉ, 1979).

Durante os três séculos da etapa da colonização, a mineração se concretizou através da lavra do ouro, a prata, o mercúrio, e em menor escala o cobre, o estanho, e o chumbo. Segundo o Conde Lemos (1790) apud Samamé (1979) na época colonial no Peru existiram 728 minas de prata, 69 de ouro, 4 de mercúrio e 4 de cobre com prata.

Durante a época republicana, que começou em 1789, a mineração se estagnou significativamente, retomando posteriormente sua hegemonia no contexto internacional através da exploração do "guano" ${ }^{4}$, posteriormente a exploração de salitre de Tarapacá, descoberto no começo do século XIX, que teve sua produção inicial em pequena escala nos começos de 1830.

A mineração como atividade industrial começou com a lavra da mina de Cerro de Pasco no departamento do mesmo nome em 1905, e em 1922 se inaugurou o complexo metalúrgico de "La Oroya" no departamento de Junín. Na ultima década do século passado foram outorgadas várias concessões mineiras como parte da política de abertura de mercados, incentivada pelo governo de Alberto Fujimori. O Anexo B mostra as principais minas e projetos existentes no Peru no ano 2010 (PERU, 2010).

Atualmente a mineração é uma das atividades mais importantes da economia do Peru, representando normalmente mais de 50\% das exportações. Em 2007 contribuiu com mais de 17 bilhões de dólares, representando 62\% das exportações conforme mostra a Tabela 3.1. Por sua própria natureza, a mineração de grande porte constitui o

\footnotetext{
${ }^{4}$ Denomina-se "guano" a um fertilizante orgânico de origem natural formado pelos excrementos e restos de aves marinhas. Importante fonte natural de nitrogênio, fósforo e potássio, elementos importantes para o crescimento das plantas.
} 
setor que gera maiores movimentos de capital, contribuindo para o desenvolvimento econômico de regiões onde são implantados os projetos.

Entre os principais minerais que o Peru produz tem-se cobre, ouro, ferro, prata, zinco, chumbo entre outros. Atualmente todos eles são bastante procurados como insumos para processos industriais de alto nível tecnológico; assim, o Peru tem uma privilegiada posição competitiva na mineração mundial, mantendo uma liderança na América do sul (PERU, 2008a).

Em 2007 o Peru foi o maior produtor na América do sul de minerais como: prata, zinco, estanho, bismuto, telúrio, chumbo, ouro e índio. Foi também o segundo maior produtor de cobre do mundo, perdendo apenas para Chile. Os principais compradores de minerais do Peru são os Estados Unidos, a Suíça, o Reino Unido; o Japão entre outros. As Tabelas 3.1, 3.2 e 3.3 mostram as exportações FOB de produtos em 2007, as reservas estimadas dos principais minérios e a posição no ranking de produção de minerais, respectivamente.

Tabela 3.1 - Exportações peruanas FOB por grupo de produtos em 2007 (milhões de US\$),

\begin{tabular}{lcc}
\multicolumn{1}{c}{ Produto de exportação } & $\begin{array}{c}\text { Valor (milhões de } \\
\text { US\$) }\end{array}$ & $\begin{array}{c}\text { Contribuição } \\
\text { (\%) }\end{array}$ \\
\hline 1. Produtos tradicionais & $\mathbf{2 1 4 9 3 , 0}$ & \\
Pesqueiros & 1456,0 & $5 \%$ \\
Agrícolas & 460,4 & $2 \%$ \\
Minerais & 17328,4 & $62 \%$ \\
Petróleo e derivados & 2248,3 & $8 \%$ \\
2. Produtos não tradicionais & $\mathbf{6 2 8 8 , 1}$ & $5 \%$ \\
Agropecuários & 1503,3 & $2 \%$ \\
Pesqueiros & 497,6 & $6 \%$ \\
Têxteis & 1729,8 & $1 \%$ \\
Madeiras e papéis, e suas & 360,4 & $3 \%$ \\
manufaturas & 803,3 & $1 \%$ \\
Químicos & 164,8 & $3 \%$ \\
Minerais não metálicos & 906,6 & $1 \%$ \\
Sidero-metalúrgicos e joalharia & 215,4 & $0 \%$ \\
Metal-mecânicos & 106,8 & $1 \%$ \\
Outros 1* & $\mathbf{1 7 4 , 5}$ & $100 \%$ \\
\hline 3. Outros 2 ** & & \\
4. TOTAL EXPORTAÇÃo & $\mathbf{2 7 9 5 5 , 6}$ & \\
\hline
\end{tabular}

Fonte: (PERU, 2008a) 
* Inclui peles, couros, artesanato. ${ }^{* *}$ Inclui venda de combustíveis e alimentos para barcos e aviões estrangeiros, reparação de bens de capital.

Tabela 3.2 - Principais reservas peruanas provadas e prováveis de minérios em 2007

\begin{tabular}{llr} 
Minério & \multicolumn{1}{c}{ Unidade } & Ano: 2006 \\
\hline Cobre & Milhares de TM & 57132 \\
Ouro & Milhares de onzas & 72823 \\
Zinco & Milhares de TM & 17106 \\
Prata & Milhares de onzas & 1915282 \\
chumbo & Milhares de TM & 6295 \\
Ferro & Milhares de TL & 1141203 \\
Estanho & Milhares de TM & 474 \\
\hline Fonte: (PERU, 2008a) &
\end{tabular}

Tabela 3.3 - Posição de produção mineral do Peru no ano 2007

\begin{tabular}{lcc}
\hline Mineral & Posição mundial & Posição na América do sul \\
\hline Prata & 1 & 1 \\
Zinco & 2 & 1 \\
Estanho & 3 & 1 \\
Bismuto & 3 & 1 \\
Telúrio & 3 & 1 \\
Chumbo & 4 & 1 \\
Ouro & 5 & 1 \\
Índio & 8 & 1 \\
Cobre & 2 & 2 \\
Molibdênio & 4 & 2 \\
Selênio & 7 & 2 \\
Ferro & 17 & 5 \\
\hline
\end{tabular}

Fonte: (PERU, 2008a)

A Tabela 3.4 e a Figura 3.1 mostram a evolução das exportações de produtos mineiros tradicionais como concentrados de minerais. Observa-se que entre 2000 e 2007 houve um incremento da ordem de $438 \%$ nos valores exportados FOB. Estima-se que os valores exportados correspondem a $95 \%$ da quantidade produzida, sendo que $5 \%$ é destinada ao consumo interno. 
Tabela 3.4 - Valores exportados de produtos mineiros FOB do ano 2000 a 2007

\begin{tabular}{lrc}
\hline Ano & $\begin{array}{c}\text { Exportações de produtos mineiros } \\
\text { (Milhões de US\$) }\end{array}$ & Número de acidentes fatais \\
\hline 2000 & 3220,13 & 48 \\
2001 & 3205,29 & 62 \\
2002 & 3808,95 & 64 \\
2003 & 4689,91 & 49 \\
2004 & 7123,82 & 50 \\
2005 & 9789,85 & 55 \\
2006 & 14707,09 & 56 \\
2007 & 17328,37 & 59 \\
\hline Total & 63873,42 &
\end{tabular}

Fonte: (PERU, 2008a)

Apesar do crescimento significativo na produção de bens minerais assim como na mão de obra empregada, houve também uma redução significativa na taxa de ocorrência de acidentes favorecida principalmente pela melhor prática das atividades de mineração, assim como pela exigência do cumprimento de melhores normas de trabalho por parte do estado, o que se evidencia também pelo crescente número de certificações de qualidade que as empresas mineiras estão recebendo como prêmio à melhor gestão de segurança e saúde ocupacional (QUISPE, 2008).

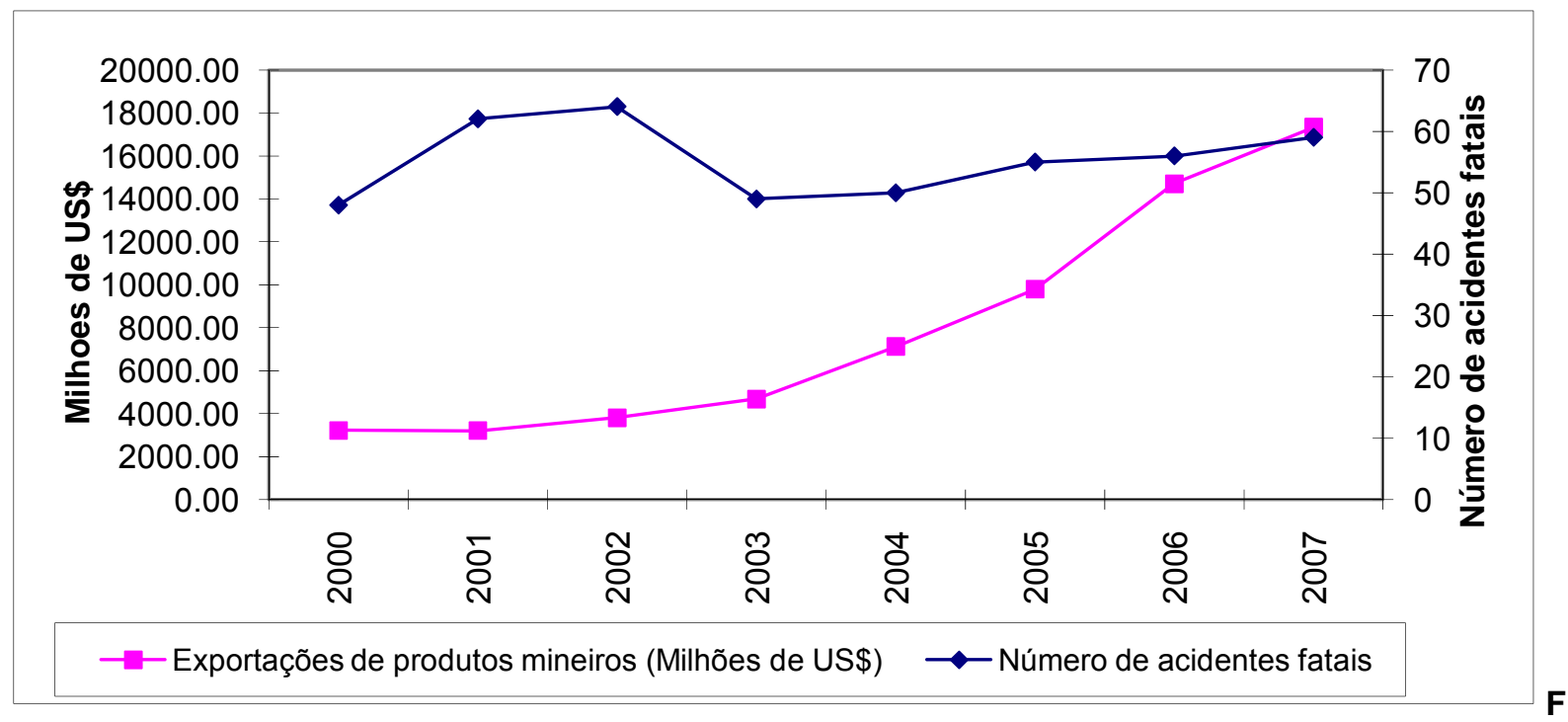

Figura 3.1 - Valores exportados de produtos mineiros FOB e número de acidentes fatais (PERU, 2008a) 


\subsection{ACIDENTES DE TRABALHO}

Os acidentes são definidos como eventos indesejados que resultam em morte, doença, lesão, dano ou outra perda (OHSAS, 1999). Para a Associação Brasileira de Normas Técnicas ABNT 14280/01 um acidente de trabalho é a ocorrência imprevista e indesejável, instantânea ou não, relacionada com o exercício do trabalho, de que resulte ou possa resultar lesão pessoal.

Barreiros (2002) define o acidente como o resultado de todo um processo de desestruturação na lógica do sistema de trabalho que, no momento, revela sua inadequação, insuficiência, seu equívoco e contradição no que diz respeito ao projeto do sistema produtivo e da concepção da organização do trabalho.

Segundo Rikkardsson e Impgaard (2004), os acidentes de trabalho são definidos como ocorrências súbitas que provocam danos aos trabalhadores provocando seu afastamento do local do trabalho por mais de um dia. Hamalainem (2009) define o acidente de trabalho como sendo uma ocorrência no local do trabalho ou fora delaS que pode resultar em morte ou afastamento por mais de três dias.

No Peru legalmente o acidente de trabalho é definido como uma ocorrência indesejável que resulta em lesão ou dano não intencional. Segundo o Ministério de energia e Minas do Peru, para que um acidente seja considerado como sendo de trabalho na mineração, deverá acontecer nas seguintes circunstâncias (PERU, 2001a):

Dentro das instalações ou áreas de trabalho:

- no horário de trabalho e durante a execução de uma tarefa ordenada pelo empregador ou seu representante;

- durante as interrupções das atividades por falta de energia, horário de refeição, capacitação com exceção de greves e paralisações; e

- os acidentes em estradas da empresa, construídas para realizar trabalhos próprios das operações mineiras, quando o trabalhador está em ação de cumprimento da ordem do empregador.

Fora das instalações ou área de trabalho:

- aqueles que acontecem enquanto está sendo realizada alguma atividade por 
ordem do empregador; e

- os acidentes que acontecem em estradas públicas, quando o trabalhador está em ação de cumprimento da ordem do empregador;

Segundo outras considerações:

- os acidentes ocorridos na realização de trabalhos de construção civil ou outros; com propósitos mineiros, sem prejuízo das responsabilidades das normas legais pertinentes; e

- os acidentes ocorridos em trabalhos temporais por contratos, também com propósitos mineiros, a solicitação do proprietário da atividade mineira.

Consideram-se ainda como acidente de trabalho as doenças profissionais (tecnopatias), que são produzidas ou desencadeadas pelo exercício de trabalho peculiar de determinada atividade, e as enfermidades relacionadas com o trabalho (mesopatias), que são adquiridas ou desencadeadas em função de condições especiais em que o trabalho é realizado e com ela se relaciona diretamente.

No contexto da discussão dos acidentes de trabalho, é importante ressaltar a definição dada aos incidentes ou "quase acidentes". Segundo a BSI 8800 (1996), um incidente é definido como um evento não planejado que tem potencial de resultar em um acidente. A OHSAS (1999) define um incidente como um evento que tenha resultado ou tenha potencial em resultar num acidente, assim, um evento não desejado sem morte, enfermidade, lesão, dano ou outras perdas é também denominado como um incidente ou "quase acidente".

Um aspecto importante dos acidentes de trabalho é que eles provocam perdas para as organizações e a sociedade. De uma forma geral, os custos decorrentes de acidentes de trabalho podem ser agrupados nas seguintes categorias:

- Tempo; horas utilizadas pelos empregados e a gerência em atividades relacionadas ao acidente assim como as horas pagas pela empresa por ausência do trabalhador acidentado.

- Materiais e componentes: custos dos materiais e componentes adquiridos ou perdidos no acidente como peças de reposição de equipamentos danificados, 
substituição de materiais danificados e a perda de valor por itens não produzidos.

- $\quad$ Serviços externos: custos de serviços externos como a substituição temporária de equipamentos, pagamento de consultorias, assim como o suporte legal.

- $\quad$ Custos governamentais (previdência, saúde, assistência social).

- $\quad$ Custos bancados pela família (medicamentos, internações, entre outros).

- $\quad$ Outros custos: custos de atividades menos frequentes em que a empresa incorre como o pagamento de multas e reabilitação.

Segundo Heinrich (1959) apud Rikkardsson e Impgaard (2004) 75\% dos custos de acidentes não são cobertos pelas companhias de seguros denominando-os como "custos ocultos". A avaliação de custos de acidentes de trabalho nas indústrias de construção civil, setor de serviços e a indústria de móveis na Dinamarca mostrou que 2/3 dos custos são visíveis e passíveis de serem cobertos pelas companhias de seguros enquanto que 1/3 são invisíveis e assumidas pela sociedade (RIKKARDSSON e IMPGAARD, 2004).

Ainda segundo Rikkardsson e Impgaard (2004), aproximadamente 65\% dos custos são decorrentes da ausência ou afastamento do trabalhador, $14 \%$ das interrupções do processo produtivo, $13 \%$ dos custos administrativos, $4 \%$ por comunicação, 3\% por iniciativas de prevenção e 1\% por outras causas. Evidentemente os custos dos acidentes de trabalho nas organizações dependem do tipo de acidente e do tempo de afastamento do trabalhador; da estrutura e política de salários da empresa; do escopo do Sistema de Gestão de Segurança, pois empresas maiores geralmente são mais burocráticas; da vulnerabilidade do processo produtivo, ou seja, da possibilidade de substituição de elementos produtivos e sua disponibilidade.

Face à análise das definições de acidente, pode-se concluir que este é o resultado do encontro entre uma situação de trabalho em particular, considerada como perigosa ${ }^{5}$, que contém em si a potencialidade de provocar danos ou perdas materiais e

${ }^{5}$ Segundo a OSHAS 18001, uma situação é considerada como perigosa (hazard) quando apresenta um potencial para provocar danos em termos de lesão, doença, prejuízo à propriedade, dano ao meio ambiente ou uma combinação destes. Esta mesma norma define risco (risk) como sendo a combinação da probabilidade de ocorrência e da consequência de um determinado evento considerado como sendo 
pessoais e o grau de liberdade dado pela organização, caracterizado pelo modo como se gerencia um sistema produtivo, para a materialização de um evento não desejado. Além disso, os acidentes de trabalho se caracterizam por provocar perdas tanto para as organizações como para a sociedade.

\subsection{ORIGEM DOS ACIDENTES DE TRABALHO}

A compreensão da gênese dos acidentes de trabalho é importante para o desenvolvimento de melhores práticas de gestão de segurança no trabalho. Medidas como treinar, conscientizar, orientar, recomendar mais cuidado, advertir, usar equipamentos de proteção individual, entre outros, carecem de sentido se não se identificam os fatores causais dos acidentes dentro de uma organização.

Tradicionalmente as análises de acidentes do trabalho concluem atribuindo culpa às próprias vítimas e negando a existência de problemas ou disfunções nos sistemas que dão origem a esses eventos. Em países em vias de desenvolvimento, os enfoques tradicionais da causalidade de acidentes são predominantes (VILELA et al., 2004).

No Peru esta abordagem é bastante hegemônica e conveniente, pois isto significa a isenção de responsabilidade do empregador. Existindo uma forte inclinação tendenciosa pela responsabilização da vítima, situação em que a empresa é favorecida juridicamente, o trabalhador passa de vítima a culpado, pois "constatado" o ato inseguro não há responsabilidade civil ou penal do empregador (VILELA et al., 2004).

Nas últimas décadas, surgiram outras abordagens e concepções que questionam a abordagem tradicional e destacam a ocorrência de acidentes como sintomas da existência de disfunções sistêmicas, sinais da ocorrência de problemas incubados que precisam ser identificados e adequadamente interpretados.

As novas abordagens têm ampliado o perímetro das análises de acidentes de trabalho, questionando os pressupostos relativos às concepções de ser humano e trabalho da abordagem tradicional. Os novos enfoques ajudam a evidenciar os resultados estéreis de práticas tradicionais: culpar e punir as vítimas, recomendar

perigoso (OSHAS, 1999). No contexto do estudo dos acidentes por queda de rochas, o perigo (danger) é a rocha instável em tetos e laterais, suscetíveis de queda por ação gravitacional ou tensional. O risco (risk) depende da probabilidade da ocorrência da queda desse bloco de rocha num período dado e as consequências que esta pode causar (Risco = Probabilidade de queda de rocha $\mathrm{x}$ consequências). 
treinamentos e normas mantendo inalterados os sistemas em que ocorrem os acidentes (ALMEIDA, 2006a). Essas novas abordagens ressaltam ainda a contribuição dos trabalhadores na construção da segurança dos sistemas.

Essa evolução significa o abandono de paradigmas tradicionais nos quais o trabalhador/vítima era responsabilizado, partindo-se para enfoques sistêmicos mais modernos e abrangentes em que se dá maior importância a fatores organizacionais, comportamentais com ênfase na dimensão humana, assim como a incorporação dos conceitos da ergonomia.

\subsection{Abordagem tradicional da origem de acidentes}

A abordagem tradicional de acidentes pressupõe que a obediência a procedimentos e normas protege o sistema contra acidentes e que esses eventos decorrem de comportamentos faltosos dos trabalhadores, originados, em parte, de aspectos de suas personalidades (ALMEIDA, 2006a). Esta abordagem tem como principal característica a atribuição de responsabilidade e culpa pelo ocorrido à própria vítima.

Entre os primeiros trabalhos que mostram esta tendência, merece especial atenção o desenvolvido por Heinrich (1926) apud Rikhardsson e Impgaard (2004), a partir de uma análise de 75.000 acidentes conclui-se que $88 \%$ dos acidentes se deve a atos inseguros, $10 \%$ a condições inseguras e $2 \%$ a causas desconhecidas.

A teoria dos dominós desenvolvida por Heinrich (1959), apud Almeida, (2006a) representa a ocorrência de um acidente como uma sequencia linear de eventos, em que antes da ocorrência do acidente estão presentes as condições imediatas representados pelos atos e condições inseguras conforme se mostra na Figura 3.2. 


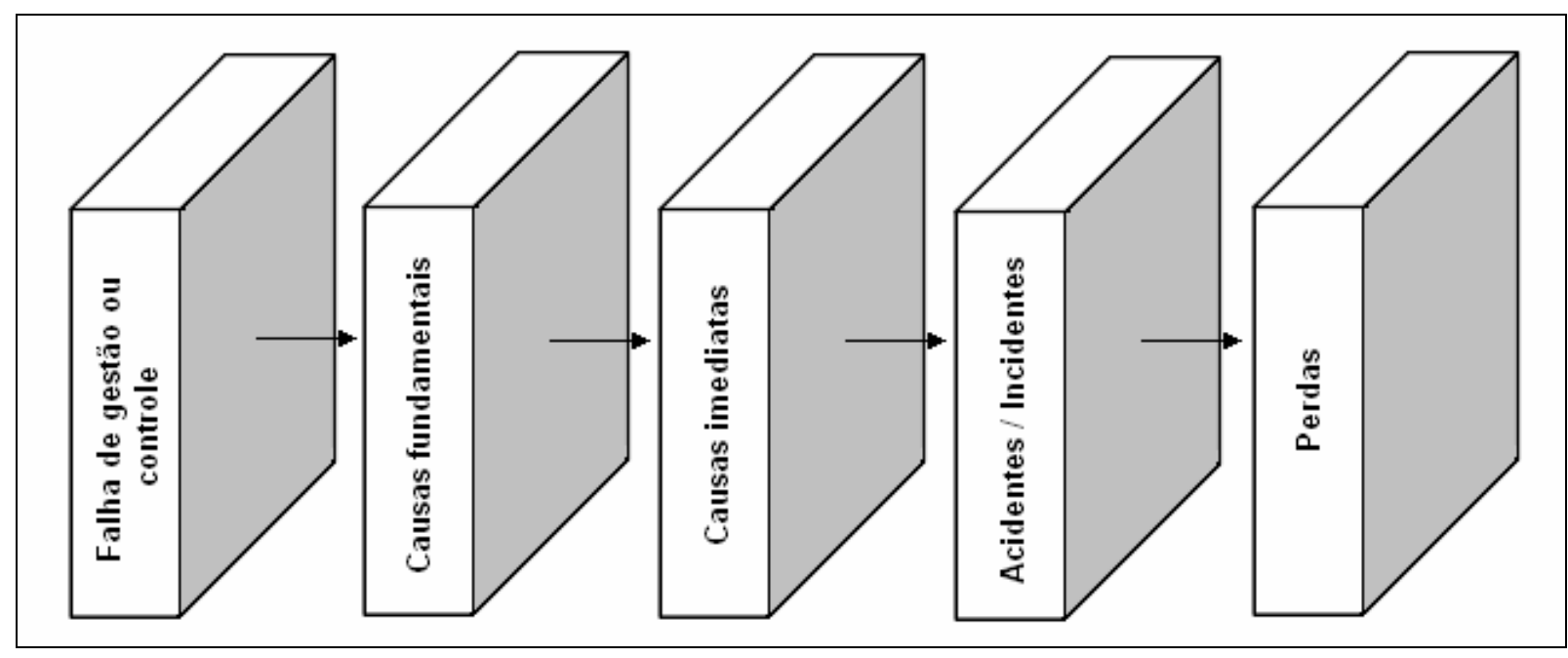

Figura 3. 2 - Teoria dos dominós (adaptado de Taralli, 2009)

O primeiro dominó representa a falha de controle ou gestão, ou seja indica que existe falta de um sistema de gestão ou uma não conformidade com uma norma. $\mathrm{O}$ segundo dominó representa as causas básicas ou fundamentais referidos aos fatores pessoais ou às condições de trabalho (insuficiência de capacidade física ou psicológica, falta de treinamento, o uso de equipamento e ferramenta indevidos, a utilização de normas e procedimentos inadequados, falta de supervisão; entre outros). O terceiro dominó representa as causas imediatas, ou seja, as condições que podem estar abaixo de padrões ou procedimentos (utilização de equipamento sem autorização ou por incompetência, equipamento ou ferramenta defeituosa, uso incorreto de um EPI, entre outros). O quarto dominó representa o acidente ou incidente e finalmente o quinto dominó representa as perdas decorrentes do acidente (TARALLI, 2009).

A prática mais difundida desta abordagem assume o pressuposto da existência de formas corretas de execução do trabalho, definidas por normas e procedimentos legais e administrativos. Nesse contexto, para a identificação de atos inseguros, bastaria só comparar o ocorrido com o padrão. Assim, esta abordagem se orienta pela punição de comportamentos errados e pela premiação dos considerados como desejados.

Esta forma de conceber o acidente entende as ações e omissões ocorridas no trabalho como produtos de escolhas conscientes dos trabalhadores, tomadas em situações em que eles teriam alternativas diferentes dentro de um leque de possibilidades, em condições de controle absoluto da situação em curso, 
desconsiderando, aspectos como o contexto, a natureza das exigências da tarefa, a variabilidade e história das formas usuais de execução do trabalho, adequação do "padrão" na vigência dessa variabilidade, e até os processos psíquicos associados, por exemplo, o estresse, as incompreensões (ALMEIDA, 2006a).

No campo da mineração, como em outras áreas, existe uma forte tendência à adoção de enfoques tradicionais; assim, a maioria das análises de acidentes encerra-se na identificação de causas diretas do acidente. Afinal, quanto menos se sabe a respeito de um acidente, maior é a probabilidade de conclusão que resulte em atribuição de causa e de responsabilidade a erro de um operador (VILELA, 2002).

Nesse contexto, a maioria das análises de acidentes de trabalho na mineração peruana acaba na identificação das condições imediatas (atos e condições inseguras da abordagem tradicional). Segundo esse enfoque, as condições inseguras se manifestam por intermédio de projetos inadequados, incertezas de caráter geológicoestrutural, programas de manutenção indevida de equipamentos e estradas, supervisão errônea, entre outros. Os atos inseguros se manifestam principalmente por meio de atitudes comportamentais consideradas como falhas ou erradas que constituem direta ou indiretamente 90\% das causas dos acidentes (BHATTACHARJEE, 1991; PAUL e MAITI, 2007; BAJPAYEE, et al., 2004).

As abordagens tradicionais da segurança do trabalho e da saúde ocupacional já foram objeto de críticas, principalmente no que diz respeito à insuficiência de sua prática e dos modelos teóricos propostos. Segundo Amalberti (1996) apud Assunção e Lima (2001), Llory (1999), Vilela et al. (2004) e Almeida (2006b), as abordagens de análises de acidentes pós-acidente, por mais que produza conhecimentos relevantes, acaba colocando a prevenção a reboque dos eventos.

Para Assunção e Lima (2001), esses enfoques além de reduzir a prevenção a uma prática meramente corretiva, colocam em evidência um problema analítico, que limita a própria inteligibilidade das causas que produzem os acidentes. Essas abordagens estão fundamentadas na prescrição de normas de regulamentação das condições de trabalho, ou seja, sobre o trabalho prescrito $^{6}$, negligência à variabilidade das condições

\footnotetext{
${ }^{6} \mathrm{Na}$ ergonomia, o trabalho prescrito refere-se às normas operacionais formalizadas em procedimentos. A forma como as atividades realmente são desenvolvidas pelos trabalhadores denomina-se trabalho real.
} 
de trabalho.

\subsection{Abordagem comportamentalista da origem de acidentes}

Os acidentes podem ser entendidos como o resultado da confluência de uma situação adversa (perigo) e a oportunidade para o ser humano executar uma tarefa conforme não planejado. Isso mostra as limitações do ser humano enquanto executante de uma determinada ação.

A abordagem comportamental da origem de acidentes defende a ideia de que as principais causas de acidentes são os "atos inseguros". Ou seja, os erros ativos dos operadores. A engenharia de segurança, ao reconhecer as limitações da abordagem tradicional, começou a se interessar pelo fator humano; reconhecendo o erro humano como sendo um fator contribuinte para a ocorrência dos acidentes de trabalho.

Os erros estão associados a fatores intrínsecos (insuficiências cognitivas e limitações de atenção) e externos (estrutura da tarefa e os efeitos do contexto) (REASON, 1999). Dessa maneira, a possibilidade de prever erros depende amplamente do conhecimento dos elementos que o produzem, ou seja: a natureza da tarefa, as circunstâncias ambientais, os mecanismos que governam o desempenho e a natureza do indivíduo.

$\mathrm{Na}$ origem dos acidentes de trabalho existe uma causa comum denominado erro ${ }^{7}$, seja ao nível de desempenho associado a habilidades, às regras e aos conhecimentos (RASSMUSSEN, 1986 apud REASON,1999). O desempenho correto e o erro são duas faces da mesma moeda. Usualmente existe uma única ou poucas formas de fazer as coisas de modo correto, porém cada passo na sequência planejada das ações ou pensamentos oferece oportunidades para cometer erros.

No contexto da discussão dos erros, é importante esclarecer a diferença entre erro e violação. Uma pessoa pode errar sem cometer uma violação; a violação implica

\footnotetext{
${ }^{7}$ Erro é o termo genérico que compreende todas aquelas ocasiões nas quais uma sequência planejada de atividades físicas ou mentais falha em alcançar os resultados desejados. Os deslizes (slips) e lapsos (lapses) são erros que resultam de alguma falha na execução e/ou armazenamento de uma sequência de ações, indiferentemente de que se o plano que guiava ele era adequado ao objetivo ou não. Os equívocos (mistakes) podem ser definidos como deficiências ou falhas no processo de julgamento ou inferência envolvido na seleção de um objetivo ou na especificação dos meios para atingi-lo, indiferente de si a ação direcionada por este esquema de decisão se desenvolve de acordo ao plano ou não (REASON, 1999).
} 
cometer um erro. Enquanto o erro implica desvio involuntário de uma ação da intenção (slips and lapses) ou a saída de uma ação planejada de alguns roteiros considerados como satisfatórios para atingir o objetivo desejado (mistakes); as violações são desvios deliberados. Esses desvios nem sempre são repreendidos; e muitas vezes são tolerados pelas partes interessadas como sendo necessários dentro de um processo produtivo (REASON,1999).

$\mathrm{Na}$ discussão da causalidade de acidentes de trabalho é importante também esclarecer a diferença entre violação e sabotagem. No segundo caso, além de ser um comportamento deliberado, existe intenção de causar dano ao sistema. As violações comumente encontradas na análise de acidentes envolvem aquelas que têm algum grau de intencionalidade, porém que não tem o objetivo de danificar o sistema (by pass) (REASON, 1999; ALMEIDA, 2006; WOODS e COOK, 2002).

As violações rotineiras são aquelas habituais, as quais são comportamentos estabelecidos de um indivíduo. As violações excepcionais são aquelas que ocorrem em circunstâncias particulares. As causas de violações rotineiras podem ser explicadas por duas causas: a tendência natural do ser humano para tomar o caminho do menor esforço e um ambiente relativamente indiferente que não coloca restrições a este tipo de comportamento. Violações excepcionais não são claramente específicas, sendo produto de uma ampla variedade de condições locais (REASON, 1999).

\subsubsection{Abordagem sistêmica da origem de acidentes}

Algumas das publicações mais recentes na investigação de acidentes de trabalho apontam a crescente importância do papel dos fatores organizacionais, como sendo determinantes para o acontecimento de acidentes de trabalho. Wright (1986), por exemplo, tem investigado a importância dos fatores organizacionais na gênese da sequência de situações de acidentes, identificando os processos perigosos, a pressão nas tarefas de produção e a falta de comunicação como sendo os maiores determinantes na ocorrência de acidentes.

Wagenaar e Groeneweg (1987) estudaram situações de acidentes no mar para identificar os tipos de erros humanos que contribuíram para sua ocorrência identificando 
os fatores organizacionais como o processo de comunicação e a pressão no trabalho como sendo os fatores que influenciam o comportamento errado ou falho das pessoas.

Shrivasta's Bhopal (1987) apud Paul e Maiti (2007) estabeleceu que os fatores causais dos acidentes podem ser agrupados em fatores humanos referidos aos recursos humanos envolvidos, os fatores organizacionais ou modos de gerenciamento e os tecnológicos, ou seja, aos recursos físicos e a tecnologia utilizada no processo produtivo numa determinada circunstância pela organização.

O enfoque sistêmico dos acidentes tem ganhando campo dentro da filosofia da origem dos acidentes. Reason (1997) apud Almeida (2006b) destaca a expressão acidente organizacional em contraposição à ideia de acidente individual, assim esta abordagem da causalidade de acidentes vem sendo cada vez mais utilizada na análise de acidentes de trabalho.

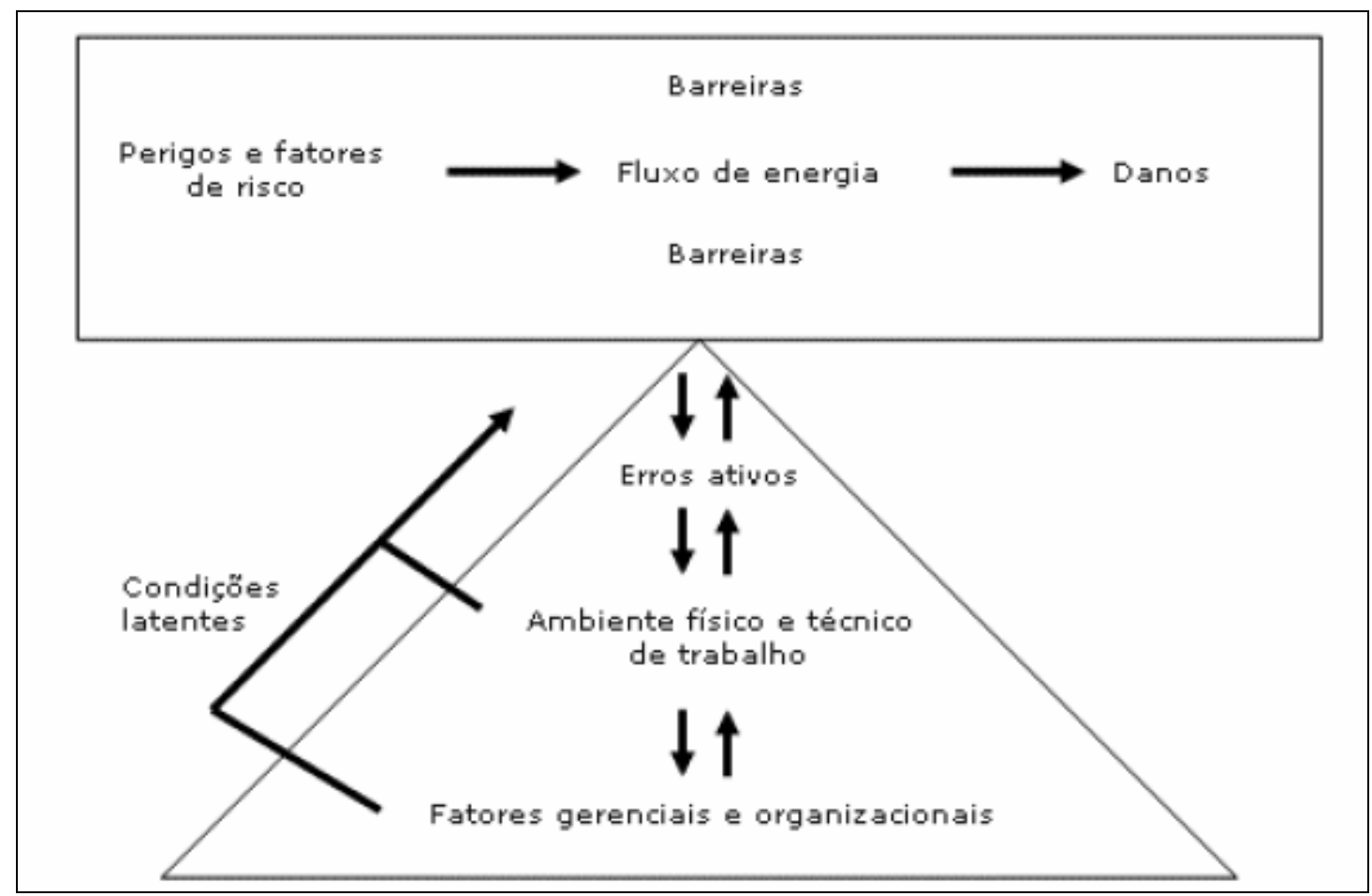

Figura 3.3 - Modelo de acidente organizacional (REASON, 1997 apud ALMEIDA 2006b)

A Figura 3.3 mostra o modelo de acidente organizacional proposto por Reason (1997). Nela, um triângulo e um retângulo são usados para representar o acidente. $\mathrm{Na}$ parte superior da figura, o retângulo representa a ocorrência do acidente provocada 
pela liberação de qualquer tipo de energia que supera as barreiras do sistema e que pode provocar qualquer tipo de perda.

O triângulo representa as condições do sistema que originam a liberação do fluxo de energia. Nas proximidades imediatas do desfecho do acidente estão os comportamentos dos trabalhadores que operam no sistema. Essas ações ou omissões estão representadas no vértice superior do triângulo e foram chamadas de erros ativos representados pelos tradicionalmente denominados "atos inseguros", cometidos pelas pessoas que estão em contato direto com o sistema.

No meio do triângulo, estão representados os fatores físicos e técnicos do ambiente de trabalho. Eles seriam as origens dos erros ativos e que, por sua vez, teriam origens nas decisões estratégicas concernentes à organização da atividade no sistema, os quais estão representados na base do triângulo.

$\mathrm{Na}$ contribuição do erro humano para a causalidade de acidentes, é importante distinguir entre erros ativos e erros latentes. No primeiro caso, os efeitos são sentidos imediatamente; já no segundo, as consequências adversas podem permanecer dormentes no sistema por um longo tempo e se tornam evidentes quando se combinam com outros fatores para quebrar as defesas do sistema (REASON, 1999; LEVESON, 2005).

Os erros ativos são pouco importantes para a prevenção e têm um impacto de curta duração sobre as defesas do sistema (REASON, 1999). Almeida (2006b) indica que devido às diferentes combinações possíveis entre as condições latentes, se criam permanentemente novas condições facilitadoras do aparecimento de erros ativos, assim não é possível eliminá-los diretamente. Os erros ativos são consequências, e não causas (REASON, 1999).

$\mathrm{Na}$ mineração como em qualquer empreendimento de engenharia, as condições latentes são representadas pelas patologias intrínsecas do sistema e surgem a partir de decisões dos projetistas, construtores, elaboradores de procedimentos e do nível gerencial mais alto. Tais decisões podem se constituir de erros ou não, além disso, decisões estratégicas podem introduzir "Patôgenos" no sistema que podem manifestarse posteriormente em eventos indesejados.

Em geral, os erros ativos são associados ao desempenho dos trabalhadores da 
frente de trabalho (front line operator) como operadores de perfuratriz, ajudantes, eletricistas, entre outros; enquanto que os erros latentes estão relacionados ao pessoal que não tem contato direto com a linha de produção, tanto no tempo como no espaço; ou seja, projetistas, gerentes de linha, gerentes de alto nível, entre outros. Os erros ativos não podem ser facilmente previstos, mas as condições latentes podem ser identificadas e corrigidas antes da ocorrência de acidentes, o que sugere que o gerenciamento deve ser mais pró-ativo do que reativo (REASON, 1999).

Correa e Junior (2007) indicam que as condições latentes têm dois tipos de consequências adversas: podem contribuir para o erro no local de trabalho (como por exemplo, pressão de tempo, sobrecarga de trabalho, equipamento inadequados, fadiga e inexperiência) ou podem criar pontos vulneráveis nas barreiras do sistema (alarmes e indicadores não confiáveis, procedimentos não exequíveis, deficiências de projeto e implantação, entre outros).

\subsubsection{A ergonomia no estudo de acidentes de trabalho}

A variabilidade das condições de trabalho é reconhecida como causadora de erros (REASON, 1999; LLORY, 1999; VILELA, 2004; ALMEIDA, 2006a). No caso de deslizes e equívocos, estes podem ser provocados pela alteração das circunstâncias e condições físicas nas quais as atividades eram rotineiramente executadas. No caso de equívocos baseados nas regras, as mudanças circunstanciais nos ambientes de trabalho implicam à aplicação errada de determinados procedimentos operacionais, o que geralmente conduz a resultados não desejados. No desempenho associado ao nível dos conhecimentos, os equívocos acontecem como consequência de mudanças situacionais, ou seja, situações novas para as quais ainda não se têm planos de contingência específicos.

Conhecer as variabilidades do trabalho e reconhecer a presença de riscos permitem também inferir como determinados fatores afetam o desenvolvimento do trabalhador. Nesse contexto, a análise ergonômica do trabalho (AET) mostrou-se como uma alternativa caracterizada por alguns princípios que remetem à singularidade dos indivíduos perante as situações de trabalho. A análise ergonômica da atividade coloca 
também em evidência que as tarefas são variáveis ao longo da jornada do trabalho, assim como no mundo interno do próprio indivíduo.

O funcionamento do homem em situação de trabalho não pode ser comparado a um modelo mecânico do tipo transformação de energia, ou a um modelo informatizado de tratamento de dados. Enquanto as máquinas não têm ideia do mundo que os rodeia, o homem sente, age e reage às mudanças do sistema, desenvolvendo representações que se modificam à medida em que esse mundo se transforma pela sua ação.

A abordagem ergonômica nega o paradigma da administração cientifica do trabalho, demonstrando que não existe o homem padrão nem tarefa padrão. Como o trabalho real se desenvolve sempre em contextos específicos, os trabalhadores, desenvolvem estratégias operatórias para cumprir as tarefas assinadas, assim como para minimizar os efeitos dos fatores de risco; ou seja, o trabalhador, além de cumprir as regras e os procedimentos formais prescritos pela organização, acaba criando caminhos (by pass) para conseguir realizar seu trabalho satisfatoriamente.

Dessa maneira, a prevenção de acidentes de trabalho, além de preconizar o cumprimento das regras formais contempladas pelos Sistemas de Gestão de Segurança e Saúde Ocupacional, deve partir para a análise ergonômica do trabalho, tendo em consideração que o trabalhador está inserido em um ambiente sócio-técnico suscetível a variações.

\subsection{ESCAVAÇÕES SUBTERRÂNEAS NA MINERAÇÃO}

As escavações subterrâneas na mineração são construídas direta ou indiretamente para a extração dos recursos minerais. Na abertura de escavações subterrâneas com propósitos de extração de minérios, basicamente se utiliza a perfuração e detonação por explosivos dentro de um ciclo de atividades. Mais recentemente, o desenvolvimento de máquinas de mineração de maior porte tem possibilitado a escarificação de rochas cada vez mais duras. Com isso, as aberturas subterrâneas sem o uso de explosivos vêm crescendo, principalmente na construção de obras civis.

Uma boa parte das escavações subterrâneas na indústria da mineração tem curta 
duração ou vida econômica restrita. Segundo Hennies e Ayres da Silva (2006), para cada escavação feita deve-se encontrar um balanço entre seu custo de construção e manutenção resultante de um acabamento menos oneroso e somente adequados para a vida e finalidade projetada.

Como as escavações subterrâneas na mineração são planejadas essencialmente baseadas em sua vida econômica, elas se distinguem das obras de caráter permanente, principalmente quanto a seu suporte e acabamento. Assim, a consolidação do maciço rochoso na mineração é, muitas vezes, feita com suporte apenas temporário ou semi-permanente (HENNIES e AYRES da SILVA, 2006).

No passado, a escolha de um método de lavra baseava-se nas técnicas aplicadas em outras minas e em experiências em jazidas de características similares. $\mathrm{Na}$ atualidade, para se abrir uma mina ou para fazer uma mudança no método de explotação, é preciso levar em consideração fatores como o investimento de capital requerido, parâmetros específicos da jazida como a sua geometria, distribuição de teores, propriedades geomecânicas do maciço rochoso, restrições ambientais, sociais, entre outros (IRAMINA, 2007).

A variação desses parâmetros e as dificuldades de quantificação dos mesmos impedem o desenvolvimento de regras rígidas e esquemas precisos de lavra aplicáveis a cada jazida em particular. Os avanços atingidos nas diferentes áreas da ciência nas últimas décadas permitiram estabelecer métodos gerais de lavra. A Figura 3.4 mostra a classificação geral destes métodos. 


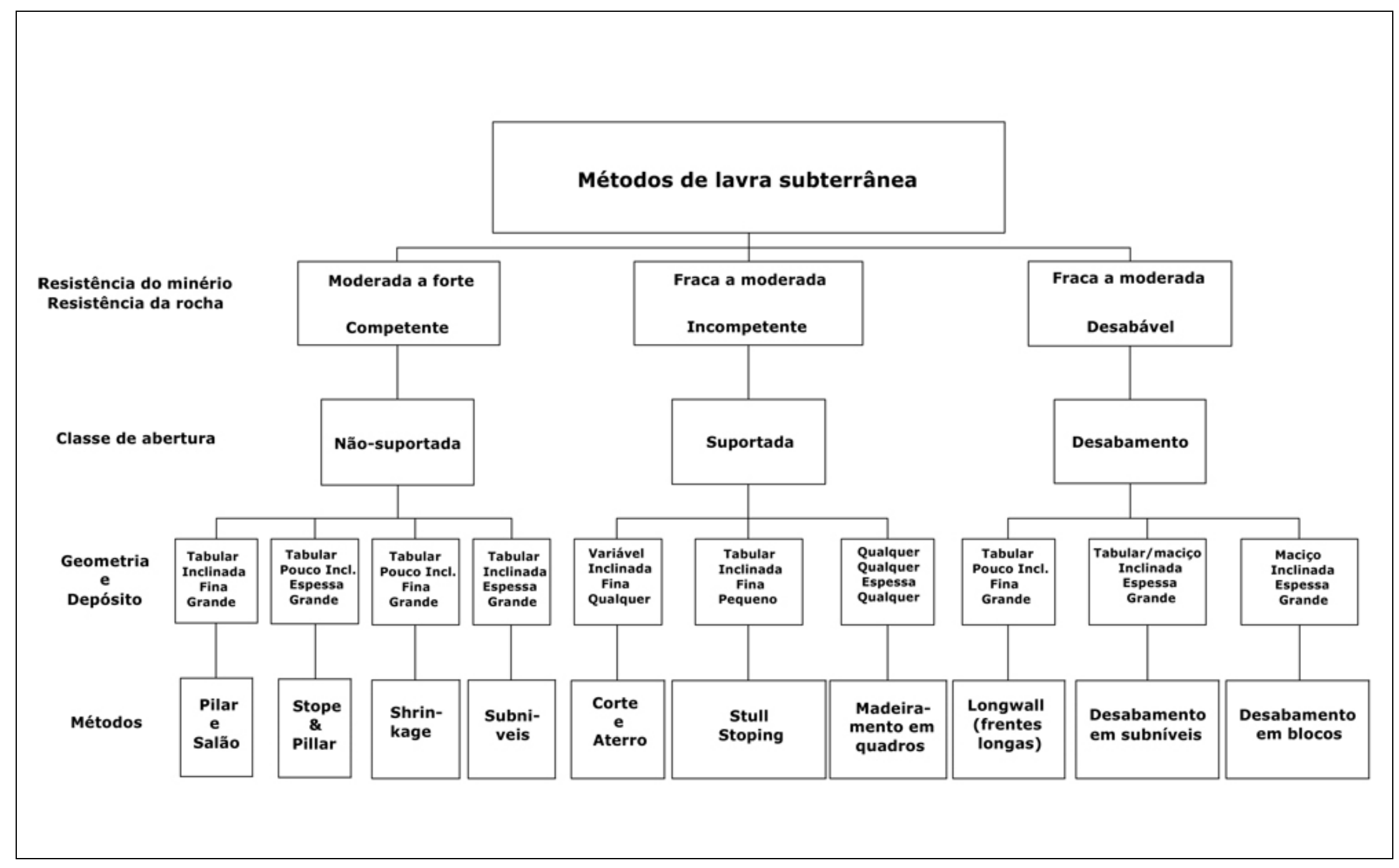

Figura 3.4 - Classificação de métodos de lavra subterrânea (TATIYA, 2005 apud IRAMINA, 2007). 


\subsection{QUEDA DE ROCHAS EM ESCAVAÇÕES SUBTERRÂNEAS}

A possibilidade de queda de rochas na mineração constitui uma ameaça para a segurança dos trabalhadores assim como para os equipamentos utilizados na mina. Além disso, a possibilidade de diluição do teor de minério pela queda de rochas na frente de lavra pode diminuir a rentabilidade da operação.

Para poder controlar estes inconvenientes, é necessário conhecer as causas que provocam a queda de rochas, visando sua eliminação ou minimização. A Figura 3.5 mostra a queda de rochas em escavações subterrâneas numa mina de cobre do Peru. Pode-se observar que as dimensões dos blocos são grandes, da mesma ordem de grandeza dos que têm efeitos significativos, tanto nas perdas de equipamentos quanto de vidas humanas.

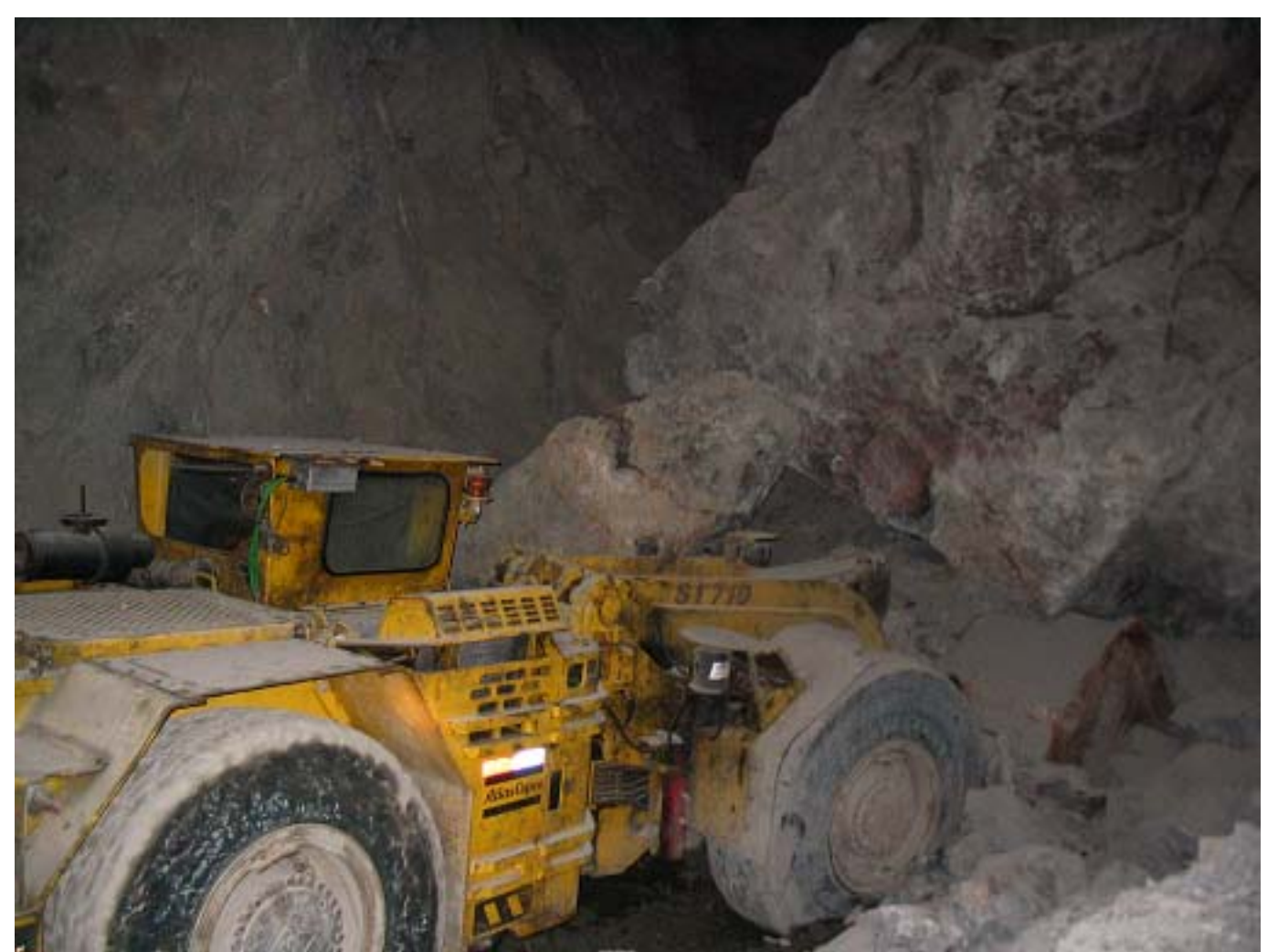

Figura 3.5 - Queda de rochas sobre a caçamba do scooptram (Fotografias da minera Condestable - Peru) 
Segundo Hoek et al. (2000), na identificação dos problemas de instabilidades em escavações subterrâneas deverão ser levadas em conta duas abordagens. Uma primeira que contempla o problema de queda de rochas do ponto de vista da escala global da mina, que por sua vez compreende o corpo da jazida, a infra-estrutura da mina assim como as propriedades do maciço rochoso hospedeiro da jazida. Uma segunda abordagem está limitada à compreensão do fenômeno das instabilidades na escala local, ou seja, nas proximidades da escavação em particular.

Além da variabilidade das condições do trabalho real nos locais de lavra, a natureza e as características da jazida assim como as propriedades do maciço rochoso hospedeiro, o estado de tensões, a geometria da escavação e a sequência de lavra influem, de um modo geral na estabilidade da mina. O sequenciamento errôneo dos painéis de lavra, o dimensionamento incorreto dos pilares, a localização inadequada de escavações subterrâneas em áreas submetidas a estados de tensão elevados podem provocar eventuais problemas de instabilidades.

Por outro lado, a estabilidade do maciço rochoso num determinado local depende das condições estruturais e do estado de tensões da região onde se encontra uma escavação subterrânea em particular. O estado de tensões nas regiões adjacentes a uma escavação em particular é influenciada pelas condições geológicas da mina como um todo. As condições de estabilidade num local são controladas significativamente pelas mudanças no estado de tensões, pela presença de feições estruturais e pela intensidade de dano provocado pela detonação de explosivos na escala local.

Diversos foram os trabalhos desenvolvidos na tentativa de explicar o fenômeno da queda de rochas e sua relação com a ocorrência de acidentes de trabalho. Phillpson (2003) pesquisou a relação existente entre a queda de rochas em escavações subterrâneas e as condições geológicas, o estado de tensões assim como o desenho da mina. Phillipson (2003) enfatiza o mapeamento geológico com a finalidade de identificar as zonas mais desfavoráveis da mina para prevenir fatalidades.

Palei e Das (2008) fizeram outro estudo para um grupo de cinco minas subterrâneas na Índia procurando estabelecer a confiabilidade de suporte de uma mina por intermédio de análise de riscos, aplicando o método de simulação de Montecarlo. A conclusão é de que a probabilidade de queda do teto de uma mina isoladamente não 
determina o risco total, uma vez que outros componentes como os custos das consequências de tais acidentes desenvolvem também um papel importante.

Para Hennies e Ayres da Silva (2006), a queda de rochas em áreas com presença de descontinuidades estruturais pode ser evitada por meio da verificação do local e a remoção dos blocos soltos. A instalação de sistemas de suporte de maciços rochosos como os constituídos por parafusos de aço, associados ou não a telas de aço podem contribuir significativamente para a redução da queda de rochas, e consequentemente reduzir o número de acidentes fatais.

No contexto da gestão de riscos, a probabilidade da queda de rochas pode ser determinada por meios subjetivos ou objetivos. Nos métodos subjetivos, o trabalhador correlaciona sua experiência com o desempenho do teto, por intermédio do julgamento subjetivo do estado do teto e laterais, em função de alguns indicadores, tais como posição e extensão dos blocos formados no teto, o tipo de som produzido quando submetido à percussão, entre outros. Na prática, a avaliação da probabilidade da queda de rochas, geralmente, é difícil por não se dispor de dados suficientes para sua análise (DUZGUN e EINSTEN, 2004).

Uma tarefa rotineira para detectar as rochas soltas consiste em bater as partes suspeitas com uma vara ou haste rígida de comprimento compatível com as dimensões das escavações. Se a rocha estiver solta produzirá um som oco; se a rocha estiver firme o som percebido é agudo. Após a identificação das rochas soltas estas deverão ser retiradas, para depois se instalar os elementos de suporte (barreiras) quando for necessário.

Na lavra de minas subterrâneas, o suporte de escavações é um trabalho adicional de alto custo e que reduz a velocidade de avanço e/ou a produção, mas é um processo importante para garantir a segurança na mina (ORTIZ, FERNANDEZ e BLAS, 2003). Entre os vários tipos de suporte artificial, destacam-se os parafusos de aço, parafusos com telas de aço, concreto projetado ou a combinação destes. O melhor sistema de suporte será determinado pela equipe de engenharia geo-mecânica em função das condições geológicas existentes no local, assim como disponibilidade de ordem técnica - econômica 


\subsubsection{Causas de instabilidades em escavações subterrâneas}

Antes da execução de uma obra subterrânea, o maciço rochoso se encontra em estado de equilíbrio. A execução da escavação e os meios pelos quais são feitos podem causar distúrbios afetando as condições pré-existentes. No contexto da mineração, esta é uma ação pela qual a organização como um todo é responsável, podendo resultar em acidentes de trabalho.

Após a ocorrência de um acidente, certamente é possível identificar as ações e/ou inações que o causaram. Em sistemas complexos, os esforços devem estar orientados a identificar as falhas na concepção dos projetos de engenharia (LLORY, 1999), ou seja, as ações preventivas devem dar maior importância aos aspectos de segurança do que aos meramente orçamentários.

Tabela 3.5 - Causas de instabilidades em escavações subterrâneas condicionadas estruturalmente Fases de construção de uma obra subterrânea (obras rasas e profundas)

\begin{tabular}{|c|c|c|}
\hline Exploração & Projeto & Construção - lavra \\
\hline $\begin{array}{l}\text { - Fraquezas não detectadas no } \\
\text { maciço rochoso; } \\
\text { - Desconhecimento da } \\
\text { espessura da camada } \\
\text { sobrejacente com potencial de } \\
\text { instabilidade; } \\
\text { - Presença de águas } \\
\text { subterrâneas; } \\
\text { - Alteração do maciço rochoso } \\
\text { por intemperização. }\end{array}$ & $\begin{array}{l}\text { - Deficiência no conhecimento } \\
\text { das propriedades do maciço } \\
\text { rochoso; } \\
\text { - Estratégias de lavra } \\
\text { inadequadas; } \\
\text { - Localização indevida de } \\
\text { aberturas e pilares; } \\
\text { - Orientação inadequada de } \\
\text { aberturas e pilares; } \\
\text { - Falha na avaliação de } \\
\text { possibilidades dinâmicas; } \\
\text { - Suporte inadequado; } \\
\text { - Escolha errônea de } \\
\text { equipamentos; } \\
\text { - Projeto indevido de sistemas } \\
\text { de desmonte por explosivos. } \\
\text { - Dimensionamento inadequado }\end{array}$ & $\begin{array}{l}\text { - Treinamento indevido; } \\
\text { - Práticas de trabalho } \\
\text { inadequadas; } \\
\text { - Degradação e perda de } \\
\text { suporte em material rochoso } \\
\text { não relatado; } \\
\text { - Deficiência de monitoramento } \\
\text { e supervisão; } \\
\text { - Uso errôneo de equipamentos; } \\
\text { - Instalação e manutenção } \\
\text { inadequada de elementos de } \\
\text { suporte; } \\
\text { - Deficiência na instalação de } \\
\text { elementos de suporte; } \\
\text { - Práticas deficientes de } \\
\text { desmonte por explosivos } \\
\text { - Drenagem inadequada da } \\
\text { mina. } \\
\text { - Execução da lavra inadequada } \\
\text { no que diz resppeito às } \\
\text { dimensões de pilares, lajes, } \\
\text { etc. }\end{array}$ \\
\hline
\end{tabular}

Fonte: adaptado de (UDD,1983)

Durante a concepção, a implementação e o aproveitamento econômico de uma escavação subterrânea, as causas das instabilidades podem ser diversas. Assim, é 
possível que a causa de queda de rochas durante a construção, ou lavra no caso da mineração, pode ser atribuída à obtenção inadequada de dados geotécnicos durante a etapa de exploração geológica e a sua interpretação equivocada na fase de projeto.

As Tabelas 3.5 e 3.6 mostram as causas de instabilidades em escavações subterrâneas condicionadas estruturalmente assim como aquelas condicionadas pelo estado de tensões respectivamente. Essas deficiências são cometidas durante as diversas fases de construção de uma obra subterrânea. Na maioria dos casos, não são adotadas as ações pertinentes por razões de custo e prazo. Os resultados destas omissões são mais onerosos quando acontecem acidentes.

Tabela 3.6 - Causas de instabilidades em escavações subterrâneas condicionadas pelo estado de tensões

\begin{tabular}{|c|c|c|}
\hline \multicolumn{3}{|c|}{ Fases de construção de uma obra subterrânea (geralmente obras profundas) } \\
\hline Exploração & Projeto & Construção - lavra \\
\hline $\begin{array}{l}\text { - Deficiência na identificação de } \\
\text { tensões pré-existentes; } \\
\text { - Falha na identificação das } \\
\text { variações e diferenças nas } \\
\text { resistências mecânicas do } \\
\text { maciço rochoso; } \\
\text { - Deficiência na identificação de } \\
\text { tensões de origem tectônica; } \\
\text { - Presença de águas } \\
\text { subterrâneas. }\end{array}$ & $\begin{array}{l}\text { - Estratégias de lavra } \\
\text { inadequadas; } \\
\text { - Deficiência de uma estratégia } \\
\text { para a maximização da } \\
\text { extração de minério; } \\
\text { - Orientação indevida de } \\
\text { aberturas e pilares; } \\
\text { - Dimensões e formas } \\
\text { inadequadas de aberturas e } \\
\text { pilares; } \\
\text { - Deficiência no sequenciamento } \\
\text { de lavra; } \\
\text { - Falha na identificação de } \\
\text { concentração de tensões; } \\
\text { - Suporte errôneo; } \\
\text { - Projeto inadequado de } \\
\text { sistemas de desmonte por } \\
\text { explosivos. }\end{array}$ & $\begin{array}{l}\text { - Pessoal treinado } \\
\text { inadequadamente; } \\
\text { - Práticas de trabalho } \\
\text { inadequadas; } \\
\text { - Efeitos de esforços altos no } \\
\text { maciço rochoso não } \\
\text { comunicados (Spalling, } \\
\text { deterioração de pilares, } \\
\text { rockbursts, etc); } \\
\text { - Deficiência no monitoramento; } \\
\text { - Lavra de regiões com elevado } \\
\text { estado de tensões; } \\
\text { - Instalação e manutenção } \\
\text { inadequada de elementos de } \\
\text { suporte; } \\
\text { - Deficiência na instalação de } \\
\text { elementos de suporte; } \\
\text { - Práticas deficientes de } \\
\text { desmonte por explosivos } \\
\text { - Drenagem inadequada da } \\
\text { mina. }\end{array}$ \\
\hline
\end{tabular}

Fonte: adaptado de (UDD, 1983)

\subsubsection{Principais tipos de instabilidade em escavações subterrâneas}

Segundo Dolinar, Mark e Molinda (2001), as minas podem ser classificadas em duas categorias: as com profundidades iguais ou menores do que 120 metros são denominadas como rasas, enquanto que as com profundidades maiores do que 120 
metros são chamadas de profundas. No estudo para determinar o projeto adequado de suporte de escavações através do uso de parafusos, determinaram que em minas rasas, as instabilidades se manifestam principalmente por ação gravitacional; enquanto que em minas profundas as instabilidades são condicionadas principalmente pela alteração do estado de tensões.

Para Udd (1983) e Hoek et al. (2000), as instabilidades de terreno na construção de obras subterrâneas em rocha podem ser agrupadas em duas categorias: instabilidades controladas estruturalmente, correspondentes a escavações ou minas rasas; e instabilidades controladas pelo estado de tensões, presentes frequentemente em minas profundas.

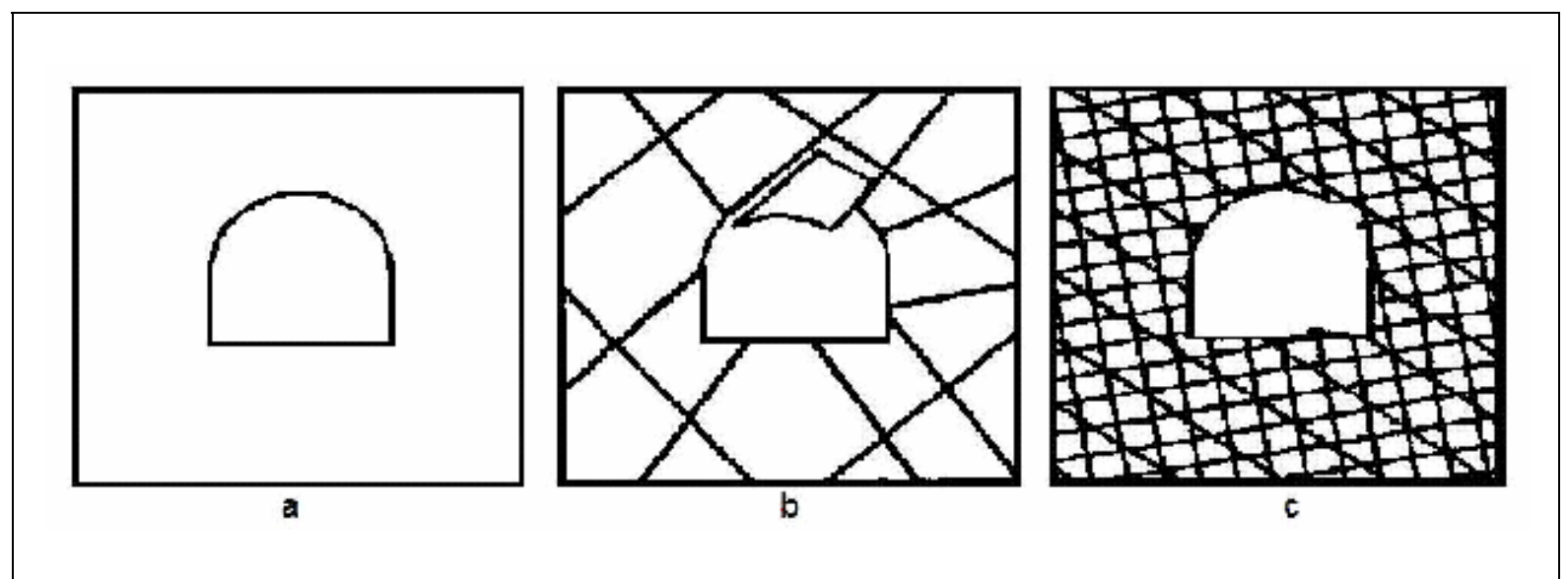

Figura 3.6 - Instabilidades estruturalmente controladas em escavações subterrâneas (adaptado de Hoek et al., 2000)

Escavações subterrâneas construídas em minas rasas e em maciços rochosos massivos $^{8}$, que são submetidos a baixos estados de tensão, não apresentam problemas de queda de rochas conforme mostrado na Figura 3.6a. Nessas condições, a colocação de elementos de suporte não é necessária, porém esses casos não são frequentes em ambientes mineiros.

Duncan e Devane (1983) indicam que as instabilidades controladas estruturalmente se manifestam através da queda de rochas decorrentes da perturbação do maciço rochoso durante a construção da escavação subterrânea, em locais onde as

8 Segundo Hoek (1998), denomina-se maciço rochoso massivo aquele que apresenta poucas descontinuidades como juntas ou aquelas em que o espacejamento entre as descontinuidades seja da mesma ordem do que as dimensões da abertura subterrânea. 
descontinuidades estruturais permitem a queda ou deslizamento de blocos de rocha por ação gravitacional conforme mostrado nas Figuras 3.6b e 3.6c.

Tendo em vista que a construção de vias subterrâneas implica a criação de uma face exposta como consequência da retirada de uma porção do maciço rochoso, o espaço livre deixado pela escavação faz com que os blocos inter-travados e resultantes da interseção de descontinuidades caiam ou escorreguem quando a força da gravidade supera os esforços cisalhantes existentes entre os blocos.

Maciços rochosos sem presença de descontinuidades submetida a elevados estados de tensão "in situ" se caracterizam por apresentar instabilidades em forma de lascamento ou até estouros de rocha (Rockburst) nas regiões adjacentes onde o esforço tangencial à compressão é alto, ou seja, na interseção do limite da escavação e o esforço principal menor conforme mostra a Figura 3.7.

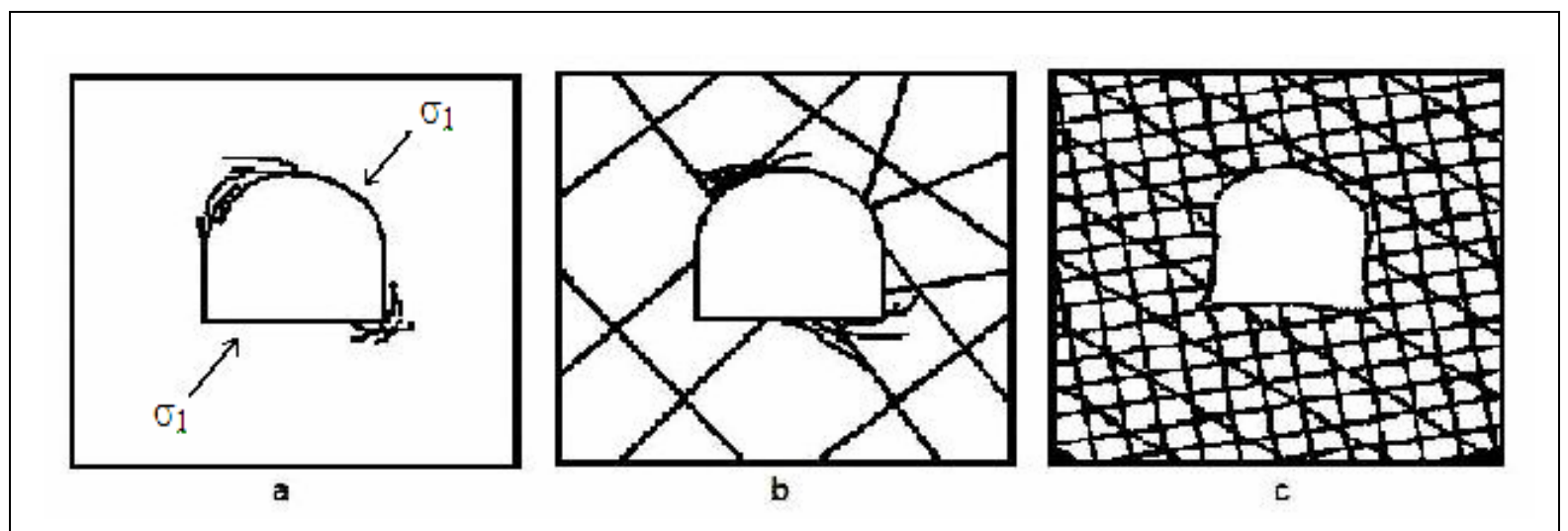

Figura 3.7 - Instabilidades estruturalmente controladas em escavações subterrâneas (adaptado de Hoek et al., 2000)

Em maciços rochosos com presença de descontinuidades estruturais submetidos a elevados estados de tensão, as instabilidades se manifestam pela queda de blocos em forma de cunha, o que é favorecido pelos esforços existentes no local. No caso extremo, onde o maciço rochoso é altamente fraturado, além da queda dos blocos resultantes da interseção de descontinuidades, esses podem sofrer uma fragmentação adicional criando material fino entre os blocos, os mesmos que favorecem a queda dos blocos em massa, podendo provocar o colapso da escavação.

A menos que sejam colocados elementos de suporte artificial para evitar a queda 
de blocos de rocha, a estabilidade da escavação subterrânea será comprometida rapidamente. Cada bloco que cai ou se desliza vai diminuir o inter-travamento dos blocos remanescentes do maciço rochoso, e deste modo permitir a queda de outros blocos. Este processo de queda vai continuar até que o efeito de arco natural no maciço rochoso evite o colapso da escavação ou até que esta seja preenchida pelo material desmoronado.

Bieniawski (1989) e Hoek (1998) expõem de forma bastante abrangente a metodologia de dimensionamento e instalação de elementos de suporte em escavações subterrâneas. Para escavações subterrâneas em maciços rochosos fraturados, que podem estar ou não submetidos a elevados estados de tensão, o controle das instabilidades pode ser feito através da colocação de parafusos sistemáticos ou não, a colocação de telas, ou uma combinação destas, dependendo dos esforços existentes no local assim como das características do maciço rochoso.

\subsection{GESTÃO DE SEGURANÇA E SAÚDE NA MINERAÇÃO}

As empresas mineiras encontram-se permanentemente diante de situações adversas como a competição internacional, a variação de preços internacionais dos metais, assim como o desenvolvimento tecnológico acelerado que obriga a adequar sua estrutura organizacional à finalidade de garantir sua sobrevivência. A gestão de segurança, também, deverá ser adequadamente gerenciada com 0 intuito de acompanhar estas mudanças.

Atualmente existe o desafio de garantir que as operações ou tarefas sejam executadas dentro de determinados parâmetros como custos, tempo, qualidade, segurança, entre outros. Além disso, a velocidade e a complexidade com que as transformações no ambiente organizacional vêm se processando, apresentam aspectos perturbadores para as principais partes interessadas, obrigando-os a formular estratégias para enfrentar essas mudanças cada vez mais rápidas.

Segundo Barreiros (2002), as mudanças que vêm ocorrendo no contexto social, econômico, político e tecnológico, intensificadas a partir dos anos 80 , provocaram transformações nas organizações e no contexto das relações de trabalho, nas quais os problemas de segurança e saúde no trabalho estão inseridos, obrigando às 
organizações a reverem seus modelos de gestão tradicionais, uma vez que estes se mostraram insuficientes para responder aos novos desafios trazidos por essas mudanças.

Ainda segundo o mesmo autor, constata-se entre os diferentes setores da atividade econômica e principalmente no setor mineral a incorporação cada vez maior dos conceitos de desenvolvimento sustentável como uma das formas de justificarem, perante as partes interessadas, uma atuação socialmente responsável. Observa-se que as questões de Segurança e Saúde no Trabalho (SST) deslocam-se do mero cumprimento de obrigações legais para o campo da introdução de princípios de gestão que permitam a melhoria contínua dos ambientes de trabalho.

\subsubsection{Enfoques da gestão de segurança nas organizações da indústria da mineração}

Existem dois enfoques de gestão da segurança nas organizações de mineração: um modelo tradicional e outro modelo moderno ou inovador. Segundo Frick (2000), os modelos tradicionais são aqueles que se caracterizam por terem iniciativas focadas para o cumprimento dos requisitos mínimos legais; têm abordagens essencialmente concebidas a partir do paradigma reducionista-mecanicista, baseados no princípio Taylorista de gestão organizacional. Já os sistemas denominados modernos ou inovadores se caracterizam por uma concepção baseada na gestão de qualidade total.

As organizações tradicionais caracterizam-se por fundamentar suas iniciativas nas necessidades de mudança comportamental do trabalhador em razão da culpabilidade que permanentemente Ihes são atribuídas pela causalidade do acidente, minimizam a importância dos sistemas de gestão de segurança, tem a participação dos trabalhadores enfraquecida e favorecem o estilo autocrático de gestão (BARREIROS, 2002).

Embora na última década tenha havido uma mudança na gestão dos sistemas produtivos na mineração peruana, as minas de médio e pequeno porte se caracterizavam ainda por ter um enfoque tradicional em que o departamento de segurança e higiene ocupacional estava subordinado à superintendência geral, que por sua vez estava sob a gerência de operações e a gerência geral como mostrado na 
Figura 3.8.

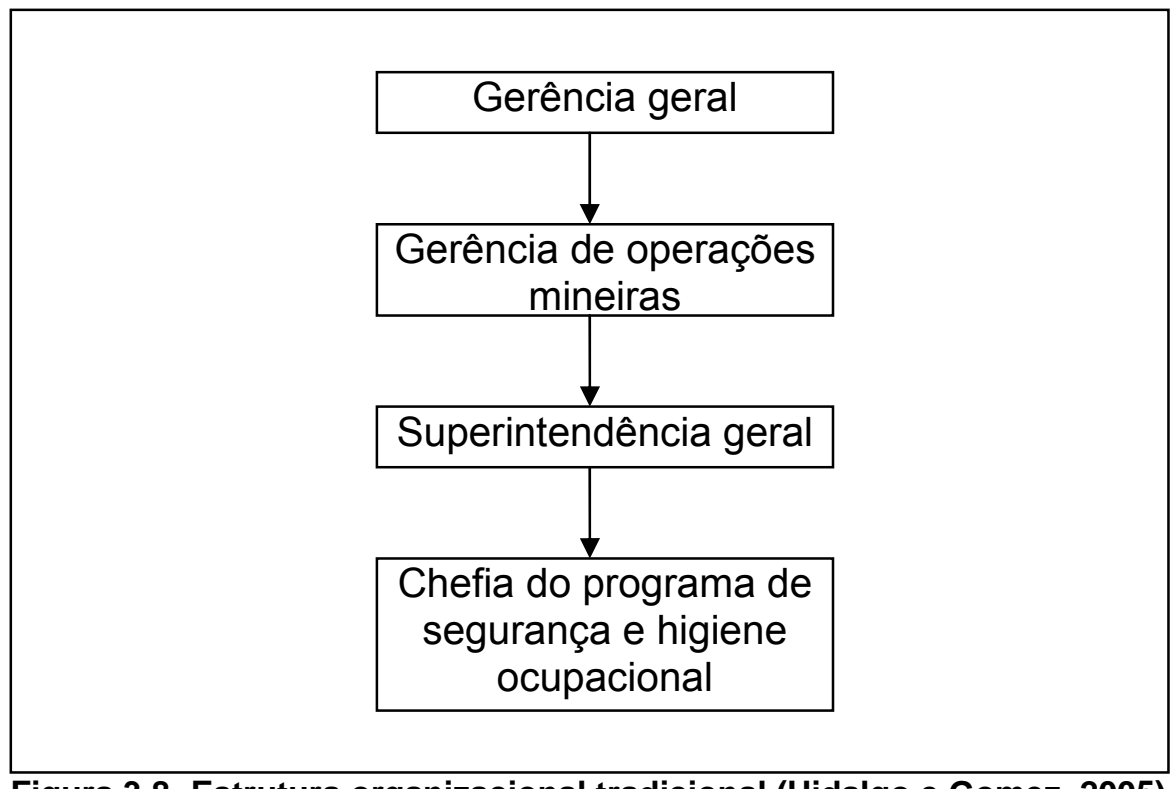

Figura 3.8- Estrutura organizacional tradicional (Hidalgo e Gomez, 2005)

Segundo Quispe (2008)A partir de 2005, como consequencia da entrada em operação de novos projetos mineiros, houve uma crescente adoção de modernos sistemas de gestão se segurança, que se caracterizam por incorporar modelos de gestão de qualidade total semelhantes aos compreendidos pela família de normas da ISO. Estes modelos foram implementados pelas organizações mineiras peruanas tanto em minas a céu aberto quanto subterrâneas de forma crescente. Nesse novo enfoque, tanto a produção quanto a segurança recebem a mesma importância conforme mostrado pela Figura 3.9. A Tabela 3.7 resume as principais diferenças entre enfoques de gestão tradicional e moderna na mineração peruana. 


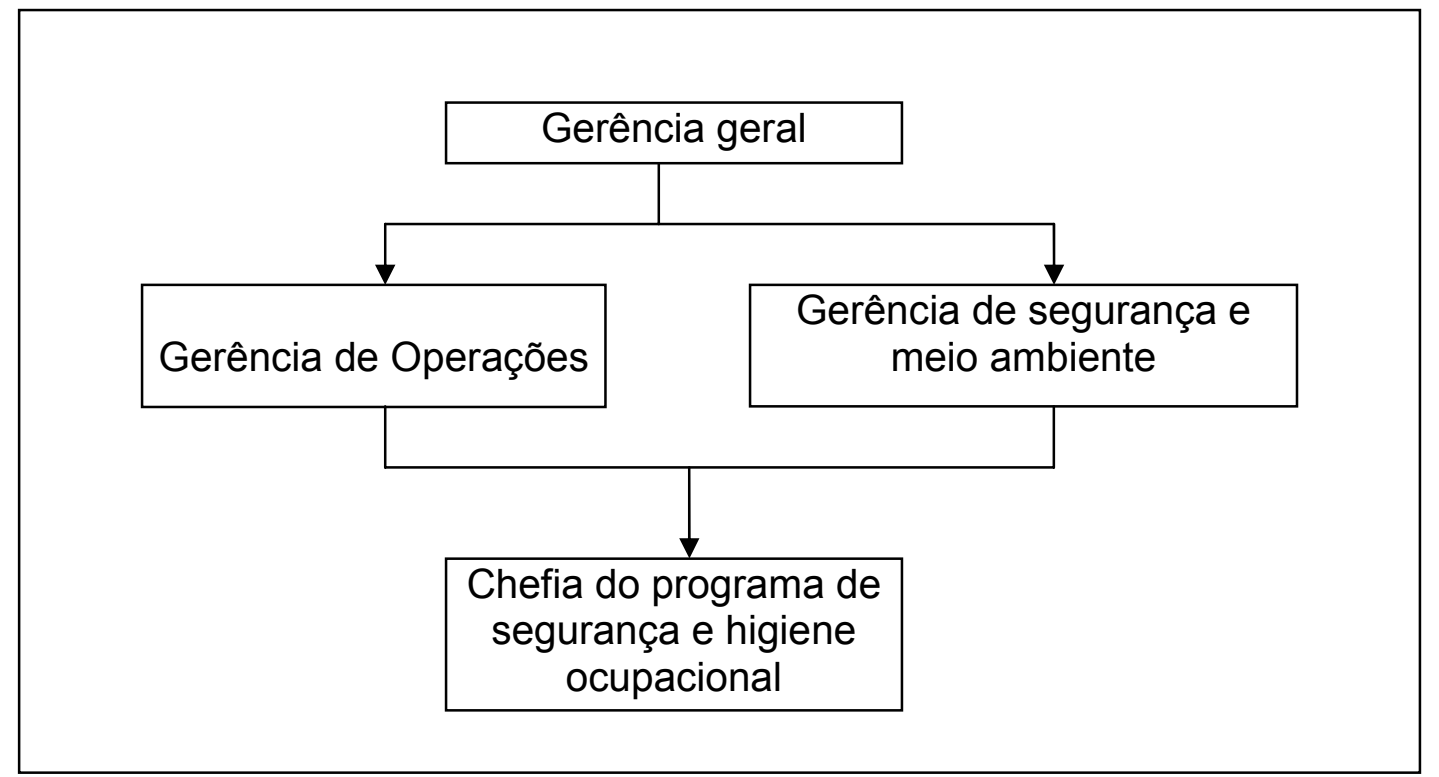

Figura 3.9 - Estrutura organizacional moderna (adaptado de Hidalgo e Gomez, 2005)

Tabela 3.7 - Diferença de enfoques de gestão de segurança entre uma organização tradicional e uma organização moderna no Peru

- A produção é mais importante;

- Os acidentes são uma parcela de sacrifício e são partes do trabalho;

- Supervisores de outras áreas não mostram interesse pela segurança;

- O departamento de segurança é o único responsável pela segurança;

- Programa de segurança reativo;

- A segurança e feita por algumas pessoas da organização;

- Educação ineficiente sobre segurança

- Crenças tradicionais (azar, destino, etc);

- Não existem líderes de segurança entre os gestores;

- Dentro da estrutura organizacional, o departamento de segurança depende das superintendências;

- Falta de visão e missão de segurança na organização.
- A segurança é tão importante quanto a produção;

- Os acidentes não são parte do trabalho, são previsíveis;

- Compartilha visão, política e princípios fundamentais de segurança;

- Autonomia na escolha de um sistema de gestão de segurança;

- Compartilhamento de estatísticas entre departamentos;

- Supervisores das diversas áreas estão bem capacitados para observar a segurança;

- O departamento de segurança é a unidade de supervisão; a responsabilidade de segurança é compartilhada desde a diretoria até o último trabalhador;

- Compartilhamento de experiências;

- Auditorias inter-cooperativas;

- Compartilhamento de programas de segurança;

- Capacitação generalizada desde a diretoria até o ultimo trabalhador;

- Não existem crenças fatalistas.

Adaptado de Hidalgo e Gomez (2005)

Os sistemas denominados modernos ou inovadores se caracterizam porque sua concepção está baseada em modelos de gestão de qualidade total assim como nos 
modelos de sistemas de gestão da família ISO. São adotados por organizações mineiras líderes em gestão de segurança, especialmente as de grande porte, dando a devida importância à segurança e higiene ocupacional, reconhecem que esta é fundamental dentro do processo produtivo, gerando compromissos fortes entre todas as partes interessadas; fortalecem a cultura de segurança em todos os níveis hierárquicos da organização por intermédio de programas contínuos de conscientização e capacitação (BARREIROS, 2002).

\subsubsection{Papel da gerência na gestão de segurança}

Segundo Shrivastava (1995) apud Barreiros (2002), as organizações convivem em cenários cada vez mais competitivos e complexos decorrentes da mudança de paradigmas econômicos, políticos e sociais. Essas mudanças apresentam aspectos perturbadores para as organizações motivando-os a re-analizar seus sistemas de gestão organizacional.

Assim, é importante que as organizações se adaptem para fazer frente a essas mudanças, procurando garantir sua sobrevivência, baseada principalmente na competitividade, eficiência, produtividade e finalmente no trabalho qualificado com qualidade de vida, satisfação no trabalho e principalmente com segurança.

Para o bom desempenho dos sistemas de gestão da segurança o comprometimento da alta gerência, tanto na atitude quanto nos aspectos comportamentais e a cultura organizacional é importante; pois é essencial que a organização como um todo perceba que a diretoria está comprometida no esforço por garantir a prevenção da segurança e saúde ocupacional, para tanto os gestores deverão transmitir com muita clareza e objetividade as políticas de gestão de segurança.

Ainda devem ser estabelecidos princípios e diretrizes bem definidas quanto aos aspectos de segurança do trabalho, assegurando que todas as partes interessadas as pratiquem, para tal, todos os trabalhadores, sem exceção, devem ser capacitados por meio de cursos e treinamentos, reuniões e deve haver até mesmo a interação direta entre a diretoria e o trabalhador mais simples.

Outra questão fundamental na função da gerência como facilitadora na gestão de 
segurança refere-se à melhoria contínua, entendida como o "processo de aprimoramento do sistema de gestão da SSO, visando atingir melhorias no desempenho global da segurança e saúde ocupacional, de acordo com a política de SSO da organização" (OSHAS, 1999); os líderes devem apresentar uma visão clara e alcançável e refletir a ideia de segurança da sua organização; por exemplo "ser a empresa mineira mais segura do país".

O conceito de melhoria contínua é inerente a uma liderança efetiva, não só na gestão de segurança, mas também envolvendo as outras tarefas e operações da organização (NBR ISO 9001, 2000a); (NBR ISO 9004, 2000b). É importante salientar que algumas vezes acontece a estagnação como consequência de um conformismo, assim, o avanço em direção aos objetivos estabelecidos deve estar acompanhado de desafios permanentes, para atingi-los e refiná-los, procurando cada vez mais alcançar um patamar superior.

Para Hidalgo e Gomez (2005), é importante a escolha de um sistema de segurança segundo a organização em particular. Embora no mercado existam vários sistemas de gestão de segurança, o ideal seria desenvolver um sistema próprio, ou minimamente adequá-lo às características da organização, pois nem sempre um sistema que funciona numa determinada organização pode funcionar em outra.

Segundo Schein (1992) apud Barreiros (2002), a cultura organizacional é definida como sendo "um conjunto de pressupostos básicos que um grupo aprendeu para lidar com seus problemas de adaptação externa e integração interna e que tem funcionado bem o suficiente para serem considerados válidos e ensinados a novos membros como a forma correta de perceber, pensar e sentir em relação a esses sistemas".

Neste contexto, na hora da escolha de um determinado sistema de gestão de segurança é importante ter em consideração a cultura organizacional da organização, pois a maioria dos sistemas está baseada no gerenciamento de informações, os quais ajudam significativamente a diminuir os acidentes e incidentes, colocando ênfase no aspecto comportamental assim como nas atitudes das pessoas.

De um modo geral, as principais funções dos gestores como dos trabalhadores dentro de uma organização podem ser indicados na Tabela 3.8. As funções dos gestores referem-se ao desenvolvimento, adaptação e implantação de procedimentos 
de trabalho. Normalmente o papel dos trabalhadores é considerado subalterno ou secundário, no entanto, a contribuição que estes podem dar é significativa quando as observações e sugestões dadas são incorporadas nos Sistemas de Gestão de Segurança.

Tabela 3.8 - Funções dos gestores e trabalhadores na gestão de segurança

\begin{tabular}{|c|c|}
\hline Gestores & Trabalhadores \\
\hline $\begin{array}{l}\text { - } \quad \text { Exercer liderança na segurança; } \\
\text { - } \quad \text { Dar exemplo por meio de seus atos; } \\
\text { - } \quad \text { Treinar seu pessoal em aspectos de } \\
\text { segurança (incluindo seus supervisores) } \\
\text { com igual importância dada à produção; } \\
\text { - } \quad \text { Fazer da segurança um valor da } \\
\text { organização; } \\
\text { - Ser responsável pela segurança da } \\
\text { - } \quad \text { Comanização como um todo; } \\
\quad \text { mudança; } \\
\text { - Supervisionar pessoalmente o } \\
\quad \text { desempenho da segurança }\end{array}$ & 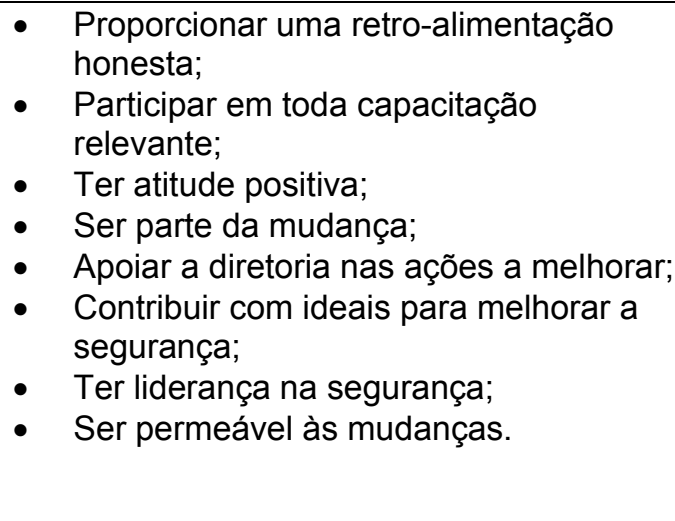 \\
\hline
\end{tabular}

(Adaptado de Hidalgo e Gomez, 2005)

Os líderes da organização conduzem as ações ou influenciam o comportamento e a mentalidade de outras pessoas, estes deverão coordenar os diferentes trabalhos dos subordinados com o intuito de que o trabalho seja mais eficiente (MAXIMIANO, 2008). Os gerentes realizam funções de planejamento, direção, organização, e controle que estão diretamente relacionados com o trabalho de segurança, qualidade e produção; o que deve ser feito de forma eficiente, mantendo uma interação entre o departamento de segurança e os outros departamentos, entendendo-se que a segurança é tarefa de todos e não apenas do departamento de segurança.

Embora sejam reconhecidos os atos e as condições inseguras como as causas dos acidentes, existe a ideia fatalista de que o "azar ou a vontade de Deus" são causadoras desses resultados indesejáveis. A existência de "desvios" dentro de uma organização é responsabilidade de todos. Os empresários por não oferecerem um local de trabalho seguro; a diretoria pela deficiência no gerenciamento da SST; a equipe técnica por projetar operações inseguras; os trabalhadores por não cumprirem os procedimentos operacionais; os governos por permitirem operações inseguras, os 
órgãos fiscalizadores por não levarem a sério as verificações das condições de trabalho. De fato, a mineração continuará sendo uma indústria perigosa, porém os riscos envolvidos podem ser diminuídos na medida em que as partes interessadas assumam seus compromissos com maior responsabilidade.

É evidente que uma administração deficiente favorece o acontecimento de acidentes; assim, a situação da segurança poderia melhorar quando os gerentes se preocupassem em exercer uma liderança efetiva e outorgassem uma proteção responsável às pessoas, equipamentos, materiais e meio ambiente.

É importante disponibilizar os conhecimentos necessários e transmiti-los aos trabalhadores sobre como desenvolver as atividades de forma mais eficiente e segura. A contribuição dos trabalhadores que interagem diretamente com os sistemas de produção será significativa na medida em que os gestores os valorizem e os incorporem nos Sistemas de Gestão de Segurança, não os considerando como meros atores passivos; e desse modo quebrar definitivamente os paradigmas tradicionais de produção ainda preponderante na indústria da mineração.

\subsubsection{Evolução da gestão de segurança na mineração peruana}

Nos últimos anos, a gestão de segurança na mineração peruana experimentou uma mudança positiva. Apesar da reconhecida importância dessa atividade econômica, ela se caracterizava por dar maior importância à produção, negligenciando os aspectos de segurança. Entre as principais características da gestão de segurança do trabalho e saúde ocupacional no século passado podemos indicar (HIDALGO e GOMEZ, 2005):

- A maioria das organizações mineiras no Peru acreditava que o papel do engenheiro de segurança na mina deveria ser desempenhado por um profissional que não tinha bom desempenho na área de produção. Acreditava-se ainda que o pessoal que trabalhava na área de segurança não precisava ter muitas habilidades profissionais.

- $\quad$ Era frequente também a existência de discrepâncias entre o pessoal de produção e segurança, pois muitas vezes embora seja reconhecida a existência de condições perigosas no local de trabalho, a gerência de operações mandava a 
execução dos trabalhos, resultando em muitos casos em acidentes pelos quais era responsabilizado o engenheiro de segurança.

- As áreas de segurança e saúde no trabalho eram as que menos recursos financeiros e técnicos recebiam. Uma boa parte das organizações só tinha o departamento de segurança por mero cumprimento às exigências legais.

- Existia a crença de que o acontecimento dos acidentes era de responsabilidade exclusiva do engenheiro de segurança; desse modo, existia uma tendência de responsabilizar o trabalhador pela ocorrência de acidentes.

- Existia a ideia de que o engenheiro de segurança estava na obrigação de defender os interesses da empresa, o que significava que na maioria das vezes o trabalhador era responsabilizado pelo acidente; isto por sua vez despertava um conflito entre a empresa e os sindicatos, conflitos que muitas vezes se materializavam em greves.

- Dentro da estrutura organizacional, a área de segurança era subordinada à superintendência; assim, o engenheiro de segurança não tinha poder para interromper as tarefas mesmo quando eram constatadas condições inseguras.

- A segurança era enxergada em muitos casos como um gargalo que comprometia a produtividade da empresa. Acreditava-se que a área de segurança só produzia custos, assim este departamento era dotado de poucos recursos econômicos e humanos. A segurança não era importante para a diretoria, pois esta carecia de cultura e liderança organizacional em aspectos de segurança.

No entanto, com a entrada em operação de projetos financiados por organizações multinacionais, houve uma melhoria significativa na gestão de SSO. A maioria das empresas de grande e pequeno porte foram implementando paulatinamente sistemas de gestão como os da família da ISO. Isso pode ser visto pelo crescente número de certificações que as empresas mineiras vêm obtendo (QUISPE, 2008).

A promulgação do Decreto Supremo No 046-2001-EM - "Reglamento de Seguridad e Higiene Minera" (PERU, 2001a) constitui uma ferramenta jurídica que torna a mineração como uma das primeiras atividades industriais a cumprir exigências compatíveis com a normalização internacional. 
Por sua vez, a implementação de Sistemas de Gestão de SSO tem contribuído significativamente para a melhoria dos indicadores de desempenho de segurança. Além disso, as empresas mineiras, a partir de programas de consultorias, vêm desenvolvendo sistemas de gestão próprios, com o intuito de permitir a melhoria contínua das suas operações (QUISPE, 2008).

Nos últimos anos, as partes interessadas vêm estimulando a melhoria na gestão de segurança a partir de prêmios patrocinados por empresas privadas, em função dos indicadores de desempenho de segurança tanto na mineração superficial, mineração subterrânea e nas atividades de beneficiamento, o que estimula por si as empresas mineiras a adotarem políticas orientadas à segurança. ${ }^{9}$

\subsection{ACIDENTES DE TRABALHO NA MINERAÇÃO}

Os ambientes de trabalho na mineração se caracterizam por apresentar intensa heterogeneidade, sendo condicionados pelas características geológicas existentes nos locais onde são desenvolvidas as minas. Os acidentes de trabalho na lavra de minas podem ser causados por diversos agentes, destacando-se os físicos e químicos como as diversas formas de energia existentes nos locais de trabalho e a presença de gases respectivamente.

A partir do registro de acidentes de trabalho fornecido pelo Ministério de Energia e Minas do Peru entre 2000 e 2007, Candia (2010b) mostra os principais tipos de acidentes de trabalho na mineração peruana, destacando-se os causados pela queda de rochas, a queda de pessoas, o tráfego de veículos, entre outros.

Os ambientes de trabalho subterrâneo se caracterizam pela presença de rochas soltas ou enfraquecidas resultantes da interferência de sua estabilidade, o que aliado à deficiência de iluminação coloca em risco o trabalhador mineiro. As operações unitárias

9 O prêmio John T. Ryan, denominado assim em honra ao fundador da empresa patrocinadora "Mine Safety Appliances (MSA)", é uma premiação que se oferece no Peru desde 1999 em reconhecimento público às empresas que se destacam nas categorias de mineração subterrânea, mineração a céu aberto, refino e fundição. Os requisitos para ser candidato a essa premiação são: não ter nenhum acidente fatal no último ano, ter mais de 200.000 Horas Homem Trabalhadas (HHT), ter um Índice de Frequência (IF) menor a 5 e um Índice de Severidade (IS) inferior a 100. A comissão qualificadora está composta pelo "Instituto de Seguridad Minera (ISEM)", a "Sociedad Nacional de Minería Petróleo y Energía (SNMPE)", o "Colegio de Ingenieros del Perú (CIP)", Osinergmin e o "Ministerio de .Energía y Minas (MEM)". 
de perfuração e desmonte provocam a alteração do estado de tensões do maciço rochoso, que aliado à existência de feições estruturais podem resultar em queda de rochas do teto muitas vezes com consequências fatais.

Acidentes por deslizamento de terreno são os provocados pelo escorregamento de blocos de rochas das fases laterais de escavações subterrâneas ou a céu aberto. As escavações realizadas em empreendimentos mineiros provocam a alteração das condições de equilíbrio natural do maciço rochoso. Além da alteração do estado de tensões; as condições hidrogeológicas do terreno como o regime de escoamento das águas de chuva, as taxas de infiltração, o modo de percolação de águas subterrâneas, entre outros são alteradas também. Essas mudanças têm efeitos na estabilidade do terreno manifestando-se na maioria das vezes em deslizamentos de terreno em massa.

Acidentes por afogamento são provocados pela inundação de minas subterrâneas e a céu aberto por fluidos líquidos ou semi-sólidos (MSHA, 2007). Este tipo de acidente acontece principalmente quando as minas estão localizadas em zonas próximas a rios, lagos ou oceanos; ou mesmo quando a carga hidráulica do lençol freático não é adequadamente rebaixada e bombeada para a superfície, criando depósitos de água no interior da mina, que se apresentam como verdadeiras armadilhas para os trabalhadores.

Acidentes fatais envolvendo asfixia em ambientes subterrâneos são frequentes e são causados pela deficiência de oxigênio. Nessas condições o oxigênio pode ter sido dissolvido em água ou utilizado para oxidar alguns componentes das rochas. Este tipo de ambientes inclui minas abandonadas ou as frentes de lavra mais profundas onde a ventilação geralmente é precária.

Segundo Torloni e Vieira (2003), a intoxicação é um processo patológico causado por substâncias tóxicas que geram desequilíbrio fisiológico com repercussões clínicas, em consequência das alterações bioquímicas no organismo. A asfixia, por sua vez, é um processo na maioria das vezes fatal, no qual o organismo deixa de receber o suprimento mínimo de oxigênio necessário para que as funções vitais do organismo humano possam se desenvolver satisfatoriamente.

Acidentes de tráfego são ocasionados nas vias de transporte de minas por veículos de grande e pequeno porte os mesmos que são utilizados nas operações e 
serviços auxiliares. Entre as principais causas deste tipo de acidentes têm sido identificados os defeitos nos veículos, as estradas defeituosas, a falta de sinalização, o excesso de velocidade, o uso inapropriado de veículos, as vias sub-dimensionadas e o descumprimento dos procedimentos operacionais.

Os acidentes durante as operações de carga e descarga de minério acontecem principalmente durante sua retirada da frente de lavra após desmonte por explosivos. Os pontos de transferência de material desmontado em minas subterrâneas são locais onde frequentemente acontecem acidentes, principalmente durante as operações de desobstrução de vias de descarga (drawpoints).

Acidentes por manobra de equipamentos motorizados e não motorizados são frequentes durante a lavra de minérios. O tamanho dos equipamentos utilizados na mineração incrementa as consequências dos acidentes de trabalho. Segundo Groves et al. (2007), os acidentes relacionados ao uso de veículos fora de estrada e equipamentos manuais não motorizados são as principais causas de acidentes fatais e lesões respectivamente.

As condições encontradas na mineração subterrânea, principalmente as de pequeno porte, obrigam os operadores a usar as ferramentas e equipamentos em posições incômodas. Em minas com baixo nível de mecanização, é frequente a ocorrência de acidente pelo uso de equipamentos como as perfuratrizes manuais, principalmente devido ao tempo de uso prolongado e às posições incômodas de trabalho.

Acidentes por afundamento de terreno estão associados à existência de espaços subterrâneos abertos deixados após a extração de material, o que se soma à falha de suporte natural ou artificial. Neste tipo de acidente, após o colapso da escavação segue o soterramento de equipamentos e trabalhadores. O desabamento ou subsidência acontece quando o minério é completamente retirado ou quando os pilares em rocha deixados ou mesmo os suportes instalados não oferecem resistência suficiente.

Os acidentes por manipulação de materiais compreendem o manuseio de materiais empacotados ou soltos através do uso de equipamentos como gruas, pontes rolantes, guindastes ou manualmente (MSHA, 2007). A movimentação de grandes quantidades de minério com a geração de material particulado em suspensão constitui 
uma condição perigosa com potencial de causar incêndios ou explosões. Essa condição perigosa enfatiza também o aspecto do armazenamento de materiais manuseados em escavações subterrâneas.

O manuseio de materiais mais pesados pode ainda exigir o uso de guindastes que são equipamentos fundamentalmente destinados a erguer cargas pesadas para locais elevados. Os acidentes associados a este tipo de equipamentos, na maioria das vezes compreende a sobrecarga, associado ao desgaste de diversos componentes como roldanas, cabos de aço, entre outros (MSHA, 2007 apud CANDIA, 2010a).

Os acidentes por queda ou escorregamento de pessoas num mesmo nível ou de alturas maiores a 2 metros são outra causa frequente de fatalidades. A maioria dos acidentes por queda de alturas se dá porque os trabalhadores não usam os equipamentos de proteção individual (EPI) como cinto de segurança, trava-quedas ou mesmo em situações em que estão usando estes EPIs, os mesmos não estão ligados às linhas de vida (CANDIA, 2010a).

A queda de pessoas nos locais de trabalho ocorre também devido a efeitos indiretos causados por descargas elétricas acidentais; pois não é pequena a quantidade de acidentes em que a eletricidade foi apenas o gatilho e as consequências graves ficaram por conta de fraturas, batidas sérias e morte por queda de alturas consideráveis. A iluminação deficiente em escavações subterrâneas é um fator de risco que pode potencializar a ocorrência deste tipo de acidentes.

Os acidentes mais frequentes associados a explosões em minas subterrâneas são causados basicamente pelo mal uso de explosivos assim como pela explosão de gases e poeiras nas escavações. Os acidentes por explosivos geralmente estão associados à práticas inadequadas do desmonte por explosivos, como por exemplo, planos de fogo deficientes, distancias de seguranca inadequadas, entre outras causas; já a explosão de gases e poeira ocorre pelas altas concentrações nas frentes de lavra favorecidos principalmente pela ventilação deficiente (CANDIA, 2010a).

Segundo Zhantao (2010), explosões de gases em minas de carvão têm sido a causa de inúmeras mortes na China. Os gases liberados na lavra quando misturados com poeiras de carvão podem incrementar dramaticamente a intensidade das explosões. Os gases resultantes de reações incompletas constituem um perigo pela 
possibilidade de provocar acidentes por explosões em minas subterrâneas.

Segundo Verakis e Lobb (2001), Kecojevic e Radomski (2005), os principais acidentes por uso de explosivos no desmonte de rochas incluem a falta de área de segurança, ultra-lançamentos, fogos prematuros, fogos mal dimensionados, assim como falta de cumprimento dos procedimentos estabelecidos para tal. Para Rejak (2001), além dos fatores antes indicados, a geologia e as descontinuidades estruturais do maciço rochoso influenciam a ocorrência de acidentes. Além disso, a variabilidade das condições de trabalho nas frentes de lavra potencializa o risco de acidentes deste tipo.

O uso de ferramentas necessárias para a manutenção de equipamentos, assim como para o ajuste de certos componentes durante a instalação de elementos de suporte e ancoragem, reparação de equipamentos, entre outros, constitui outra causa de acidentes de trabalho. Estes acidentes ocorrem principalmente pelo uso inapropriado de ferramentas.

Acidentes por energia elétrica acontecem em instalações e serviços que direta ou indiretamente empregam este tipo de energia, que em função da sua natureza, complexidade e intensidade apresentam riscos significativos para o trabalhador, usuários e terceiros, sendo consequentemente uma causadora potencial de fatalidades.

Os danos mais frequentes, do ponto de vista material, se caracterizam pela promoção de incêndios, explosões e danos aos próprios equipamentos elétricos. Do ponto de vista pessoal, a eletricidade pode causar queimaduras e choques elétricos, colocando em risco a vida das pessoas e outros seres vivos (CANDIA, 2010a).

\subsection{ACIDENTES POR QUEDA DE ROCHAS NA MINERAÇÃO SUBTERRÂNEA}

Uma das causas mais importantes de acidentes na mineração subterrânea é a queda de rochas. O trabalhador mineiro encontra-se exposto a esse risco desde o momento que entra na mina até o momento em que sai dela. As estatísticas de acidentes de trabalho na mineração em diversos países ainda mostram que a queda de rochas é uma das principais causas de fatalidades (PEAKE e ASHWORTH, 1996; (DUZGUN e EINSTEN, 2004; PALEI e DAS, 2008; MAITI et al., 2009).

Os acidentes por queda de rochas geralmente são difíceis de prever devido às 
condições de incertezas geológicas existentes nos locais de lavra. A complexidade estrutural assim como a variabilidade dos parâmetros geomecânicos do maciço rochoso são fatores determinantes que favorecem a queda de rochas (DUZGUN e EINSTEN, 2004; PALEI e DAS, 2008).

As consequências da queda de rochas numa mina em particular estão relacionadas à geologia do local, ao método de lavra e ao tipo de suporte utilizado. Além disso, a queda de rochas pode ter consequências diferentes, dependendo do local onde esta ocorre; por exemplo, um acidente desse tipo terá maiores consequência em vias subterrâneas permanentes do que em vias de uso temporário.

Entre as principais consequências de um acidente por queda de rochas, podemos indicar: mortes e ferimentos, dano a equipamentos, interrupções e retraso nas operações de lavra, operações emergenciais, entre outros. A Figura 3.10 mostra os instantes após a queda de rochas na frente de lavra numa mina do Peru. Este acidente aconteceu no momento em que o trabalhador estava fazendo uso de jato de água para a retirada de bloco solto, ferindo-o gravemente, porém sem lhe provocar a morte.

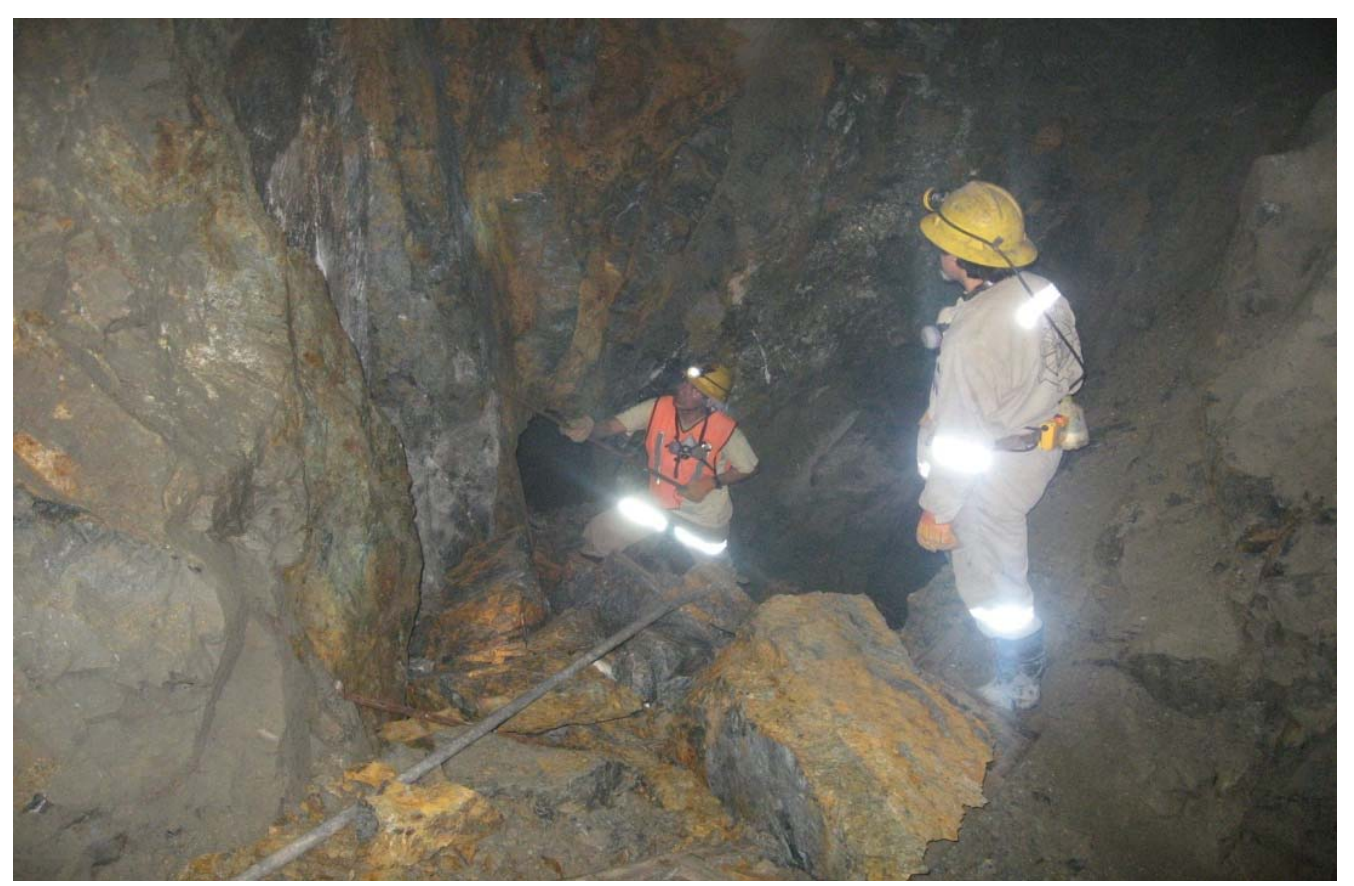

Figura 3.10 - Queda de rochas em escavações subterrâneas (Fotografia do autor na mina Condestable - Peru) 
Segundo o MSHA (2006) apud Faria (2008), na mineração dos Estados Unidos, a mineração subterrânea é considerada como uma das atividades mais perigosas do setor mineral, com taxas de mortalidade cerca de 20 vezes maiores do que em outros setores industriais. Salienta-se ainda que aproximadamente $75 \%$ das mortes estão relacionadas à queda de rochas de tetos e laterais em escavações subterrâneas.

Segundo o Safety in Mines Research Advisory Committee da África do Sul SIMRAC, para o período compreendido entre 1996 e 2005, os acidentes por queda de rochas foram a principal causa de fatalidades (MSHA, 2006 apud Faria, 2008). A partir de estudos sobre a tendência de acidentes fatais na mineração da África do Sul, Leger (1991) afirma que para minas de ouro com profundidades maiores do que 3000 metros as quedas de rocha multiplicam por três vezes a taxa de mortalidade média do setor.

$\mathrm{Na}$ mineração peruana, os acidentes por queda de rochas são a principal categoria de acidentes de trabalho, representando aproximadamente $40 \%$ das fatalidades. A maioria dos acidentes está associada à retirada (abatimento) de rochas soltas de tetos e laterais das escavações subterrâneas (chocos), principalmente nas frentes de produção depois da retirada do material desmontado.

Segundo Faria (2008), a tarefa de detecção e abatimento de "chocos" é conhecida também como "fazer a segurança". Para Otterman et al. (2002), a retirada de rochas soltas é uma atividade estressante e perigosa, pois o trabalhador é incapaz de trabalhar a uma distância segura, sendo, na maioria das vezes, obrigado a trabalhar diretamente debaixo de rochas instáveis durante a atividade.

Ainda segundo Otterman et al. (2002), os equipamentos utilizados no abatimento de rochas são arcaicos. Após a detecção de rocha solta, o abatimento é feito manualmente na maioria das minas, utilizando-se barra metálica de comprimento variável com reforço em uma das suas extremidades. Para o abatimento de rocha solta, o operador posiciona-se próximo ao "choco", o que aumenta o risco de ser atingido durante o processo conforme mostrado na Figura 3.11.

A tarefa de detecção de situações de risco de queda de rochas é crucial para a segurança dos trabalhadores. Segundo Faria (2008), o abatimento de "chocos" ocorre em duas etapas distintas: 1) identificação e detecção de "chocos"; 2) correção e remedição do risco. Dessa forma; o risco potencial existe enquanto houver deficiências 
no processo de detecção e abatimento de rochas soltas.

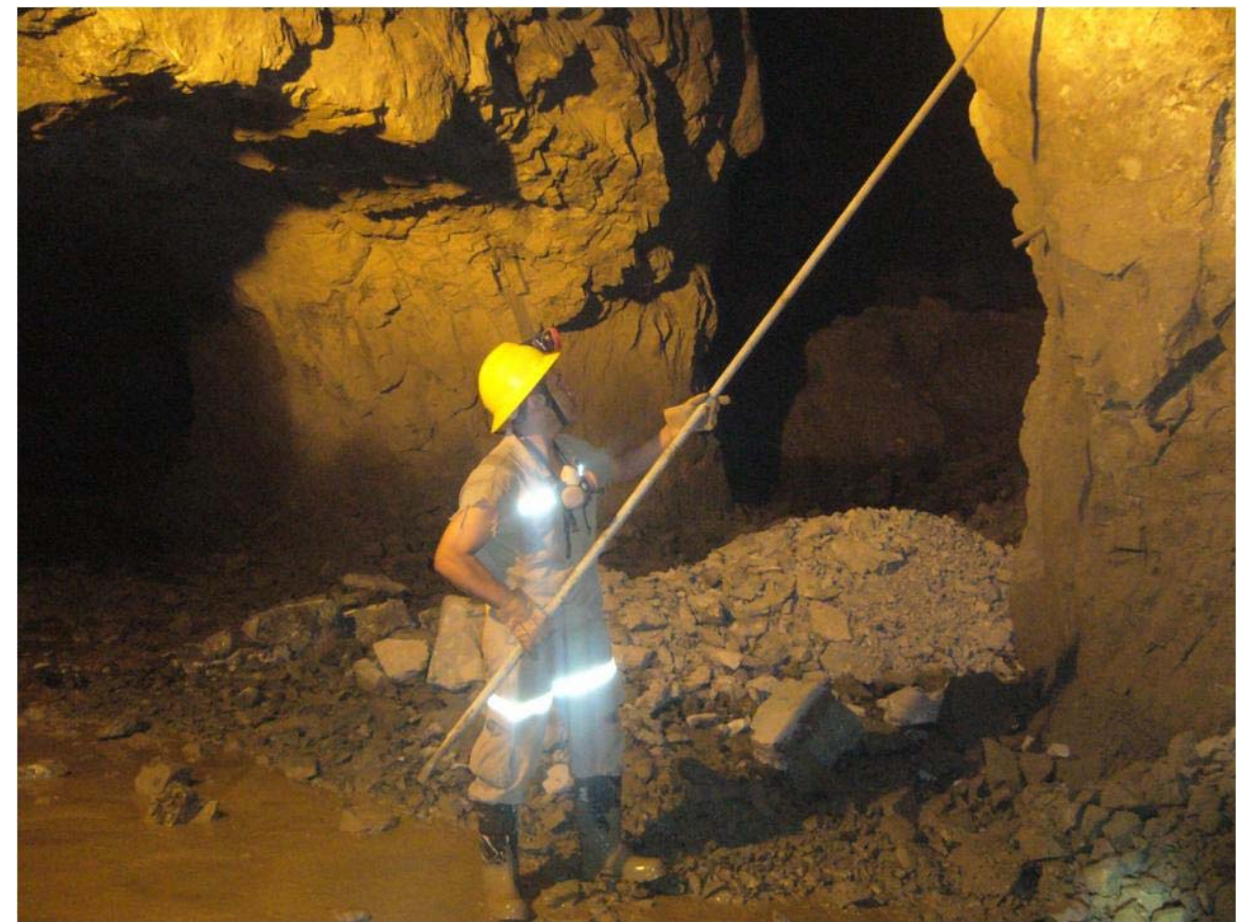

Figura 3.11 - Retirada manual de rocha solta (Fotografia da minera Condestable)

Segundo Peake e Ashworth (1996), existem basicamente três razões pelas quais o processo de detecção de rochas soltas pode falhar:

a) procedimento inapropriado; ocorre quando a operação não resulta em sucesso, mesmo com procedimento realizado corretamente por operadores competentes e em condições adequadas para a detecção de rochas soltas. Nesse caso, existem poucas escolhas, sendo necessárias mudanças no procedimento;

b) delegação da tarefa para operadores que não têm condições físicas e cognitivas necessárias;

c) situações de ambiente ou pressões de produção, as quais podem compreender vários fatores, como por exemplo, o ambiente em que o trabalho é desenvolvido, prioridades estabelecidas pela supervisão ou gerência, problemas com o abastecimento de materiais, disponibilidade e confiabilidade de equipamentos, entre outros.

Para minimizar os riscos durante a retirada de rocha solta, podem ser consideradas técnicas alternativas como o uso de sistemas de sucção, hidro- 
jateamento, uso de vibrações nos tetos e laterais ou mesmo o abatimento mecanizado por meio de "scalers", conforme a Figura 3.12.

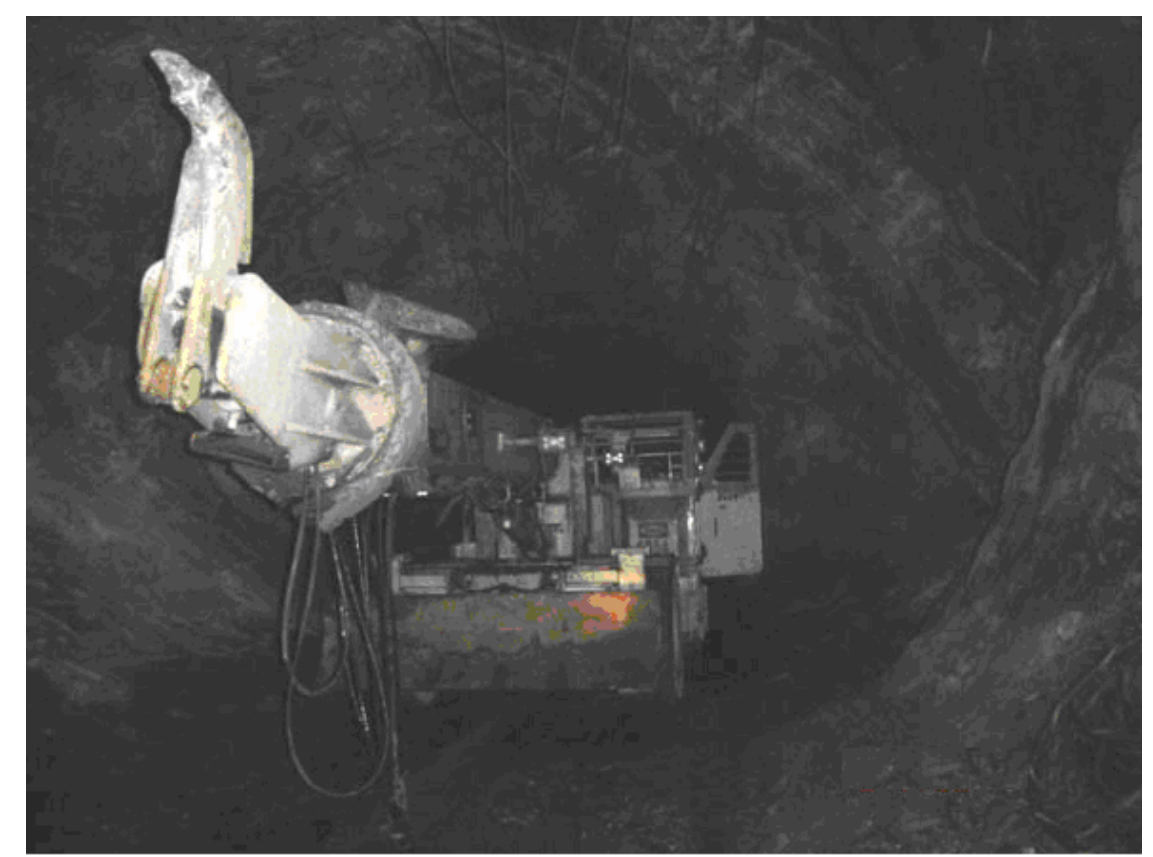

Figura 3.12 - Retirada mecanizada de rocha solta com scaler (Faria, 2008)

Contudo, a prevenção de queda de rochas em áreas com presença de descontinuidades estruturais pode ser evitada através da inspeção rotineira das escavações subterrâneas, seguido da remoção dos blocos soltos e a instalação de elementos de suporte. Embora o suporte de escavações signifique o incremento dos custos e a alteração dos programas de produção, sua implementação é um processo importante para garantir a segurança das operações.

\subsection{MODELAGEM MATEMÁTICA NA SAÚDE OCUPACIONAL}

Um modelo pode ser definido como uma representação conveniente de alguma coisa importante. Quando a representação consiste de componentes quantitativos, este modelo é chamado de matemático, que pode se definir também como uma representação ou interpretação simplificada da realidade por meio de equações ou fórmulas matemáticas. $O$ processo de modelagem consiste em uma série de atividades 
complexas associadas ao desenho de modelos representando o mundo real e sua solução (MASSAD et al., 2004).

Para construir-se um determinado modelo, várias decisões são necessárias quanto aos critérios para seu desenvolvimento, tanto explícitas quanto implícitas; como por exemplo, decidir por um modelo específico ou geral, numérico ou analítico, estocástico ou determinístico, qualitativo ou quantitativo, entre outros. $O$ tipo de modelo a ser construido depende do fenômeno a se estudar (SILVA, 1995).

O desenho de modelos matemáticos de sistemas reais complexos (e frequentemente não lineares) é essencial em vários ramos das ciências. Os modelos propostos e desenvolvidos podem ser usados, por exemplo, para explicar o comportamento subjacente de sistemas reais, além de servir de instrumento de predição e controle (SILVA, 1995), (MASSAD et al., 2004).

Alguns autores classificam os modelos matemáticos na área epidemiológica como estocásticos e determinísticos. Segundo Massad et al. (2004), esta diferenciação é tênue sob o ponto de vista conceitual, porém robusta sob o ponto de vista instrumental. Os modelos estocásticos por incorporarem elementos probabilísticos, são particularmente adequados para lidar com populações pequenas em que o elemento chance pode influenciar os resultados. Os modelos determinísticos são adequados às situações em que se conhece o processo a ser modelado com grande acurácia, ou aquelas em que se está lidando com populações suficientemente grandes.

A estrutura do modelo (não do sistema) é escolhida a partir de famílias de modelos conhecidos com flexibilidade e aplicações anteriores bem sucedidas. Isto implica que os parâmetros $^{10}$ do modelo, também, carecem de significado físico ou mesmo verbal. Estes são escolhidos apenas para ajustar os dados observados da melhor forma possível. Essa classe de modelos, também, é chamada de modelos a posteori, significando que o modelo é construído depois que os dados são escolhidos. Exemplos desta classe de modelos são os ajustes de dados por meio de técnicas estatísticas de regressão (MASSAD et al., 2004).

\footnotetext{
${ }^{10}$ Os parâmetros são definidos como as quantidades que definem o comportamento dinâmico do sistema (MASSAD et al., 2004)
} 
Não existe nenhum mecanismo formal para orientar a escolha nem mesmo uma melhor definição aceitável sobre qual é o melhor modelo. O melhor modelo é aquele que tem o menor tamanho; incluindo-se as informações que especificam tanto a forma do modelo quanto o valor dos parâmetros e a forma de comunicarem-se os resultados.

A parcimônia é uma das qualidades que os modelos matemáticos devem ter: quanto menor o número de unidades e processos que dêem conta do fenômeno, melhor o modelo. A generalidade é outra qualidade requerida: quanto maior o espectro de abrangência do fenômeno coberto pelo modelo, maior a probabilidade de ele ser verdadeiro e a capacidade preditiva, ou seja, a possibilidade dos modelos serem utilizados como ferramentas na tomada de decisão antecipando cenários. (WILSON, 1998, apud MASSAD et al., 2004).

De uma forma geral, pode-se definir como propósitos da modelagem matemática:

- $\quad$ Auxiliar a compreensão dos fenômenos em termos científicos;

- Identificar os parâmetros que regem o comportamento do sistema e quais destes são passiveis de estimativa;

- $\quad$ Estabelecer instrumentos com capacidade preditiva.

\subsection{MÉTODOS DE REGRESÃO LOGÍSTICA (MRL)}

A Regressão Logística (RL) é um dos instrumentos estatísticos mais expressivos e versáteis de que se dispõe para a análise de dados na área epidemiológica (SILVA, 1995). Sua origem se deu na década de 1960 com o trabalho desenvolvido por Cornfield, Gordon e Smith (1961) apud Silva (1995) relacionado aos riscos de uma pessoa padecer de uma doença cardíaca.

Walker e Duncan (1967) apud Silva (1995) contribuíram significativamente para o desenvolvimento desta técnica estatística que permite estimar a probabilidade de ocorrência de um determinado evento em função das variáveis presentes. Deste modo, seu uso vem se intensificando desde a década de 1980, favorecido principalmente pelo desenvolvimento contínuo dos recursos computacionais.

Segundo Hosmer e Lemeshow (1986), Agresti (1996); Paula (2004), a RL vem se 
mostrando um dos principais métodos de modelagem estatística de dados. A aplicação dos MRL serve para a análise de dados de resposta binária, ou seja, admite apenas dois resultados possíveis (satisfatório/insatisfatório, sucesso/insucesso, bom/ruim, entre outros).

O resultado esperado (variável dependente) é aquele que se pretende relacionar com as demais variáveis independentes de interesse. Mesmo quando a resposta de interesse não é originariamente do tipo binário, sua aplicação é possível por intermédio do uso de artifícios, de modo que a probabilidade de ocorrência do evento esperado possa ser modelada por meio desta metodologia.

No cotidiano é comum encontrar situações práticas em que esse tipo de resposta aparece. Por exemplo, o resultado de um exame de laboratório pode ser positivo ou negativo; o resultado da inspeção de uma peça recém fabricada, defeituosa ou não; uma criança nasce ou não com uma doença congênita; um trabalhador que sofre um acidente de trabalho tem que ser hospitalizado ou não; um acidente de mineração é causado por queda de rochas ou por outras causas, entre outros exemplos.

O que se procura mediante o uso da regressão logística é, a principio, expressar a probabilidade de que aconteça o evento em questão como função de certas variáveis independentes, que se presumem com sendo relevantes. Assim, os MRL são modelos estatísticos que permitem estabelecer a relação entre:

- Uma variável dependente qualitativa dicotômica (regressão logística binária ou binomial) ou com mais de dois valores (regressão logística multinomial); e

- Uma ou mais variáveis explicativas independentes, ou co-variáveis qualitativas ou quantitativas;

A expressão matemática de partida nos MRL é apresentada pela Equação 3.1.

$$
P\left(Y=1 / x_{i}\right)=\frac{e^{b_{0}+\sum_{i=1}^{n} b_{i} \cdot x_{i}}}{1+e^{b_{0}+\sum_{i=1}^{n} b_{i} \cdot x_{i}}}
$$

Sendo $P\left(Y=1 / x_{i}\right)$ a probabilidade de que $Y$ adote o valor de 1 (presença da característica estudada) na presença das co-variáveis $\mathrm{x}_{i}\left(\mathrm{x}_{i}\right.$ é um conjunto de $\mathrm{n}$ covariáveis $\mathrm{x}_{1}, \mathrm{x}_{2}, \ldots, \mathrm{x}_{n-1}, \mathrm{x}_{n}$.). Os componentes desta equação são: 
$e=2,718$ é a base do logaritmo Neperiano;

$b_{0}$ : constante do modelo ou termo independente;

$n$ : o número de co-variáveis;

$b_{i}$ : os coeficientes das co-variáveis;

$x_{i}$ : as co-variáveis que formam parte do modelo.

Se dividirmos a Equação 3.1 pelo seu complemento obteremos sua chance ${ }^{11 \text {, }}$ obtendo-se uma expressão matemática mais simples que está dada pela Equação 3.2.

$$
\frac{P\left(Y=1 / X_{i}\right)}{1-P\left(y=1 / X_{i}\right)}=e^{b_{0}+\sum_{i=1}^{n} b_{i} \cdot x_{i}}
$$

Embora a Equação 3.2 seja mais simples do que a Equação 3.1, a sua interpretação ainda é difícil. Se realizarmos uma transformação logarítmica com o logaritmo natural, obteremos uma equação linear, que obviamente sob o ponto de vista matemático é mais manipulável e de fácil compreensão conforme mostrado na Equação 3.3.

$$
\log \left(\frac{P\left(y=1 / X_{i}\right)}{1-P\left(y=1 / X_{i}\right)}\right)=b_{0}+\sum_{i=1}^{n} b_{i} \cdot x_{i}
$$

A expressão à esquerda na Equação 3.3 é denominada de "Logit" , que é o logaritmo natural das chances da variável dependente; isto é, o logaritmo da razão de proporções de sofrer acidente por queda de rocha em relação outro tipo de acidente. $O$ termo à direita da igualdade é a expressão de uma reta, semelhante ao do modelo geral da regressão linear.

As estimativas dos coeficientes do modelo e seus desvios padrão são feitas pelo

${ }^{11}$ A chance (odds) ou razão de probabilidades, pode ser definida como a razão entre a probabilidade de que um evento aconteça e a probabilidade de que não aconteça; ou seja, é um número que expressa quanto mais provável é que o evento em questão se produza a que não se produza. 
cálculo de estimativas de máxima - verossimilhança ${ }^{12}$, que são estimativas que maximizam a probabilidade de obter valores da variável dependente $Y$ proporcionados pelos dados da amostra. Estas estimativas não são de cálculo direto como no caso das estimativas dos coeficientes de regressão linear múltipla feita por meio do método dos mínimos quadrados. Como o cálculo é complexo, normalmente se faz uso de softwares específicos, o que permite determinar os coeficientes da regressão, seus desvios padrão associados e as covariâncias entre as variáveis do modelo.

É importante ressaltar que a regressão linear apresenta uma diferença a respeito do modelo de regressão logística. No modelo de regressão linear, assume-se que o desvio padrão de cada coeficiente segue uma distribuição normal de média 0 e variância constante (homoscedasticidade). No caso do modelo de regressão logística, a variável dependente não é contínua, podendo adotar somente valores de 0 ou 1, porém nenhum valor intermédio.

Para a comprovação da significância estatística de cada coeficiente do modelo, podem ser empregados basicamente três métodos (o estatístico de Wald, o estatístico G de razão de verossimilhança e o teste de Score) (GRANADO, 2009). Para o desenvolvimento do presente trabalho, foi utilizado o estatístico de Wald por ser o mais apropriado para este tipo de estudo.

O teste de Wald é a razão entre o coeficiente $\beta_{i}$ e seu respectivo desvio padrão (se), conforme mostrado na Equação matemática 3.4; de modo que, ao nível $\alpha=0,05$, só é necessário analisar se $|Z|>1,96$. Nesse caso, se declara que $\beta_{i}$ é significativamente diferente de zero, e deverá ser mantido no modelo (SILVA, 1995).

$$
Z=\frac{\beta_{i}}{s e \beta_{i}}
$$

De um modo geral, na formulação de um modelo de Regressão Logística, semelhantemente à regressão múltipla, é necessário estimar os parâmetros $\beta_{0}, \beta_{1}, \beta_{2} \ldots$, $\beta_{k}$, a partir de uma matriz empírica do tipo:

12 O método da máxima-verossimilhança fornece os valores para os parâmetros a serem estimados $(\beta i)$ que maximizam a probabilidade de se obter o conjunto de dados existentes, ou seja, tornam o conjunto de dados mais verossímil (Silva, 1995). 


$$
\left[\begin{array}{ccccc}
Y_{1} & X_{11} & X_{12} & \ldots & X_{1 k} \\
Y_{2} & X_{21} & X_{22} & \ldots & X_{2 k} \\
\cdot & \cdot & \cdot & \cdot & \cdot \\
\cdot & \cdot & \cdot & \cdot & \cdot \\
\cdot & \cdot & \cdot & \cdot & \cdot \\
Y_{n} & X_{n 1} & X_{n 2} & \ldots & X_{n k}
\end{array}\right]
$$

A primeira coluna é composta somente por algarismos cujos valores são "0" ou "1", sendo que cada linha representa o resultado da medida das variáveis $Y, X_{1}, X_{2} \ldots$, $X_{n}$ num indivíduo da amostra; por exemplo, $X_{43}$ representa o valor da terceira variável explicativa para o quarto indivíduo da amostra estudada; desta maneira, a matriz tem tantas linhas como indivíduos tem a amostra. Esta matriz constitui a entrada (input) com que os softwares operam, por sua vez a estimativa dos parâmetros $\beta_{0}, \beta_{1}, \beta_{2} \ldots, \beta_{k}$ constituem as saídas (output) que produzem. Como o processo de estimativa é complexo, devem ser utilizados computadores dotados de pacotes específicos para esta finalidade.

Após a estimativa dos coeficientes de regressão e seus correspondentes desvios padrão, devem-se calcular os correspondentes intervalos de confiança para as estimativas feitas. Cada intervalo de confiança será calculado sob a hipótese de que os coeficientes tenham distribuição normal. Desse modo, para um determinado coeficiente $\beta_{k}$ seu intervalo de confiança ao 95\% estará dada pela Equação 3.5 .

$$
I C_{95 \%} \beta_{k}=\left[\left(\beta_{k}-1,96 s e \beta_{k}\right),\left(\beta_{k}+1,96 s e \beta_{k}\right)\right]
$$

O uso de MRL permite também estimar a razão de chance (odds ratio), ou seja, quantas vezes o risco de um individuo exposto é mais alto (ou baixo) em relação ao não exposto sob determinadas condições. Esse indicador também é conhecido como razão dos produtos cruzados. 


\section{ESTUDO DE ACIDENTES POR QUEDA DE ROCHAS NA MINERAÇÃO PERUANA}

\subsection{DESEMPENHO DA SEGURANÇA NA MINERAÇÃO PERUANA}

Apesar da evidente importância da mineração como atividade econômica no cenário econômico peruano, esta se caracteriza, também, pelos impactos sociais e ambientais causados durante seu exercício. Nesse contexto, a mineração tem sido reconhecida como uma das causas mais importantes de acidentes de trabalho quando comparada com outras atividades econômicas.

Tabela 4.1 - Acidentes de trabalho indenizados pelos sistemas de previdência social pública e privada no Peru por tipo de atividade econômica

\begin{tabular}{lcc}
\hline \multicolumn{1}{c}{ Tipo de atividade } & $\mathbf{2 0 0 6}$ & $\mathbf{2 0 0 7}$ \\
\hline Agricultura, caça e silvicultura & 6 & 8 \\
Pescaria & 5 & 7 \\
Mineração & 125 & 86 \\
Manufatura & 101 & 86 \\
Eletricidade, gás e provisão de água & 7 & 7 \\
Construção & 49 & 35 \\
Comércio atacadista e de varejo; Conserto de automóveis, & 12 & 6 \\
motocicletas e bens pessoais e domésticos & 3 & 3 \\
Hotéis e restaurantes & 3 & 31 \\
Transporte, armazenamento e comunicações & 18 & 0 \\
Intermediação financeira & 0 & 7 \\
Aluguel de bens imóveis e atividades empresariais & 10 & 8 \\
Administração pública e defesa e previdência social compulsória & 7 & 1 \\
Educação & 1 & 5 \\
Saúde e assistência social & 1 & 13 \\
Atividades sociais e comunitárias & 1 & 0 \\
Manutenção de casas com empregadas domésticas & 0 & 0 \\
Organizações extraterritoriais & 0 & 1 \\
\hline Não classificáveis por atividade econômica & 0 & 346 \\
\hline Total & & 5 \\
\hline Fonte (ILO, & 304 \\
\hline
\end{tabular}

Fonte (ILO, 2010).

A Tabela 4.1 mostra o número de acidentes de trabalho indenizados pelos sistemas de previdência social público e privado no Peru durante os anos de 2006 e 
2007 (ILO, 2010). Evidentemente, os números mostrados na tabela são significativamente inferiores ao número de acidentes de trabalho que acontecem na realidade. Isso porque em países em vias de desenvolvimento existe uma alta taxa de trabalho informal, ou mesmo devido à elevada taxa de sub - notificação de acidentes de trabalho. No entanto, a Tabela 4.1 mostra a importância da mineração enquanto causadora de acidentes, o que faz com que essa atividade econômica seja fiscalizada de forma mais rigorosa do que as outras.

A Tabela 4.2 mostra o número de trabalhadores empregados na mineração peruana assim como o número de acidentes fatais e o correspondente número de vítimas entre 2000 e 2007 . Percebe-se que houve um crescimento da ordem de $89,73 \%$ no número de trabalhadores. Pode-se ver ainda que, neste período, o ano em que aconteceu o maior número de acidentes fatais foi 2002 com 64 eventos, tendo 73 vítimas com óbito.

Tabela 4.2 - Número de trabalhadores, acidentes e vítimas fatais na mineração de 2000 a 2007

\begin{tabular}{cccc}
\hline Ano & Número de trabalhadores & Número de acidentes fatais & Número de vítimas fatais \\
\hline 2000 & 71.144 & 48 & 54 \\
2001 & 66.873 & 62 & 66 \\
2002 & 67.861 & 64 & 73 \\
2003 & 71.322 & 49 & 54 \\
2004 & 90.895 & 50 & 56 \\
2005 & 98.705 & 55 & 69 \\
2006 & 108.495 & 56 & 65 \\
2007 & 134.980 & 59 & 62 \\
\hline
\end{tabular}

Fonte (PERU, 2010).

A Figura 4.1 mostra a evolução do comportamento da taxa de mortalidade na atividade da mineração peruana, embora no período compreendido entre 2000 e 2007 o número de trabalhadores quase tenha dobrado, a taxa de mortalidade mostra uma tendência decrescente. Assim por exemplo, em 2000, a taxa de mortalidade foi de 75,90 para cada 100.000 trabalhadores, enquanto que no ano 2007 foi de 45,93 por cada 100.000 trabalhadores. Pode-se ver ainda que em 2002, ano em que houve o maior número de acidentes fatais, a taxa de mortalidade é de 101,57 por cada 100.000 trabalhadores (PERU, 2010). 


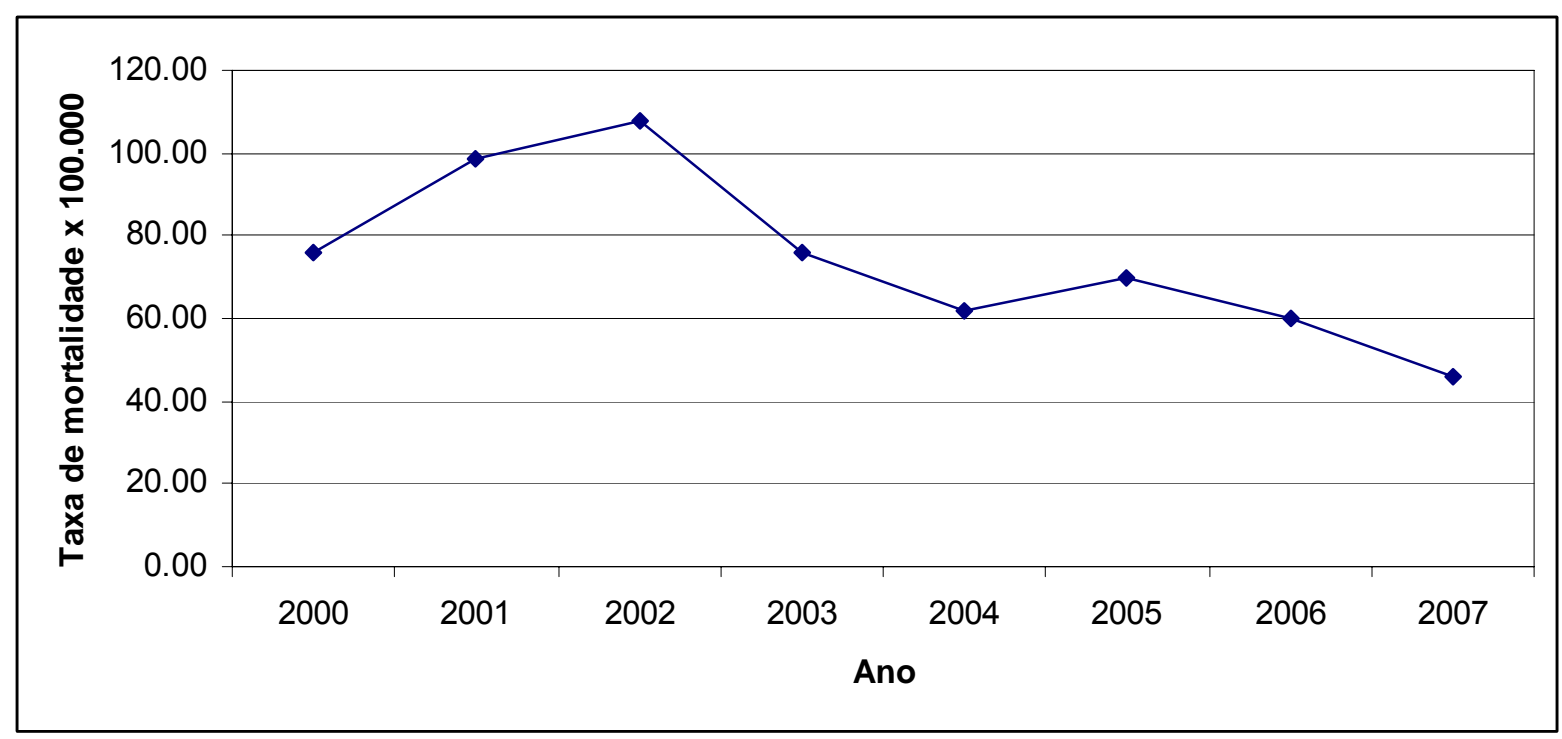

Figura 4.1 - Evolução da taxa de mortalidade na mineração peruana de 2000 a 2007 (Adaptado de PERU, 2010)

Apesar das melhorias significativas nos indicadores de segurança, refletida principalmente pela diminuição da taxa de mortalidade, o desempenho da segurança na mineração quando comparado com outros países de tradição mineira ainda é desalentador (QUISPE, 2008).

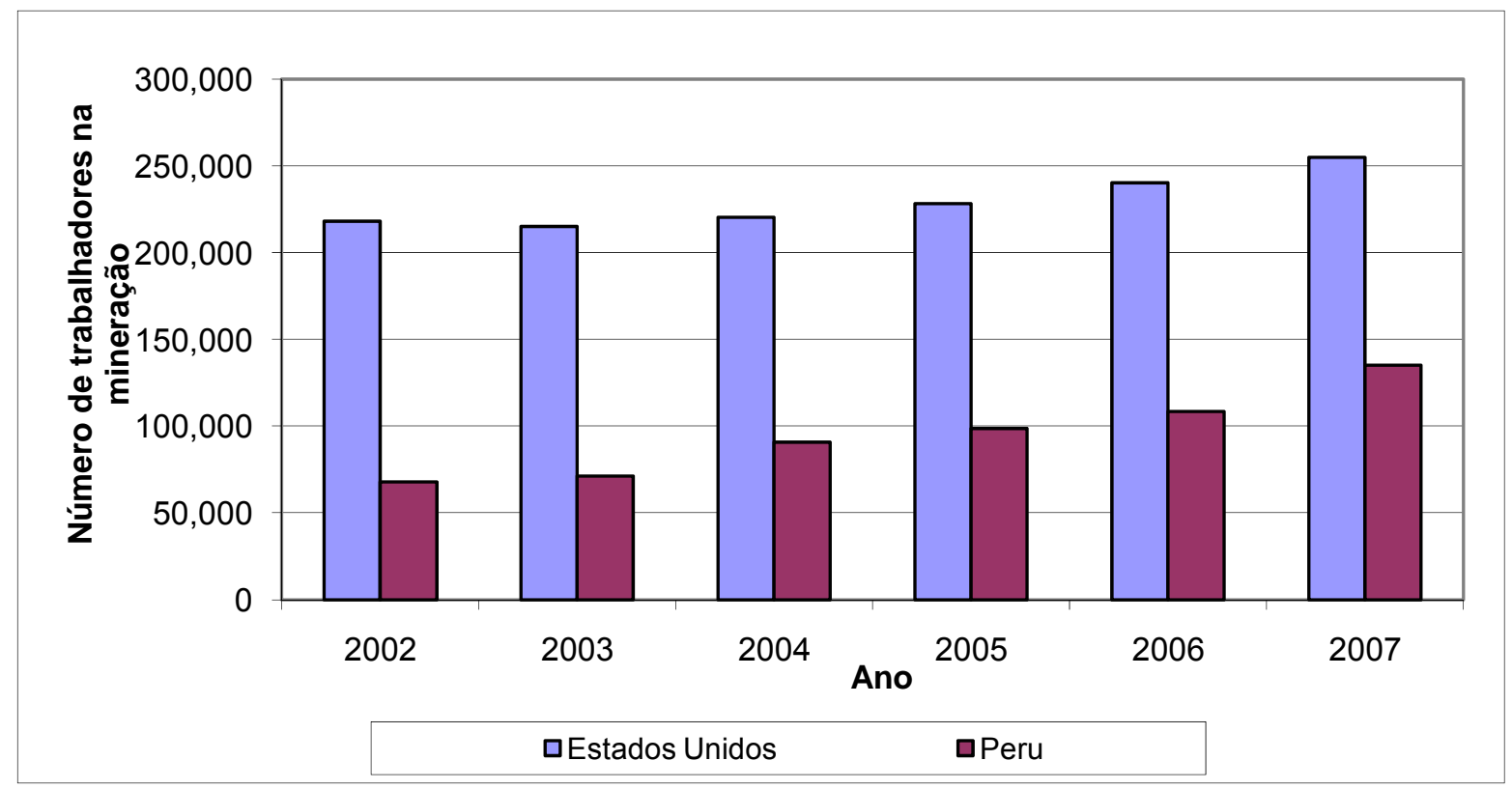

Figura 4.2 - Comparativo do número de trabalhadores na mineração metálica e não metálica entre USA e Peru (MSHA, 2010) 
A Figura 4.2 compara o número de trabalhadores empregados na mineração norte-americana metálica e não metálica (sem considerar a mineração de carvão) assim como no Peru de 2002 a 2007. Observa-se que, em 2002, o número de trabalhadores nos Estados Unidos era três vezes maior do que no Peru; já para em 2007 o número de trabalhadores era quase o dobro.

Para este mesmo período pode-se observar na Figura 4.3 que o número de vítimas fatais em acidentes na mineração metálica e não metálica (com exceção da mineração de carvão) nos Estados Unidos é significativamente menor, assim por exemplo, no ano 2007 houve um total de 33 vítimas fatais nos Estados Unidos, enquanto que no Peru houve um total de 62 vítimas. O menor número de vítimas pode ser explicado principalmente porque em países mais desenvolvidos as partes interessadas impõem maiores restrições (MSHA, 2010).

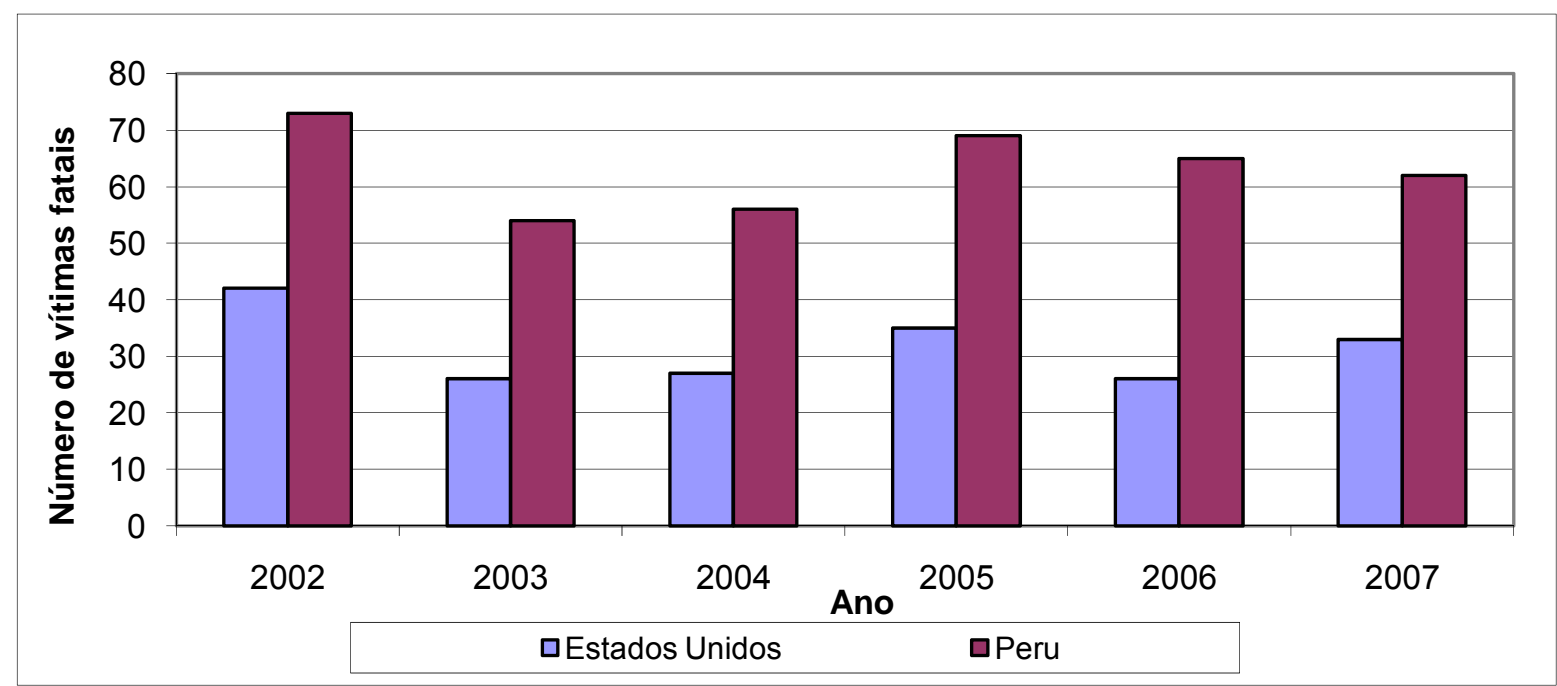

Figura 4.3 - Comparativo do número vítimas fatais na mineração metálica e não metálica entre USA e Peru de 2002 a 2007 (MSHA, 2010)

Ainda na Figura 4.4, pode-se observar o comparativo da taxa de mortalidade entre os dois países; assim, por exemplo, em 2007, a taxa de mortalidade na mineração norte-americana foi de 12,93 a cada 100.000 trabalhadores, enquanto que no Peru foi de 45,93 a cada 100.000 trabalhadores; ou seja, este indicador mostra que a taxa de mortalidade no Peru foi aproximadamente três vezes maior do que nos Estados Unidos, mostrando claramente que o assunto da segurança do trabalho em países em vias de 
desenvolvimento, particularmente na mineração, merece especial atenção ${ }^{13}$.

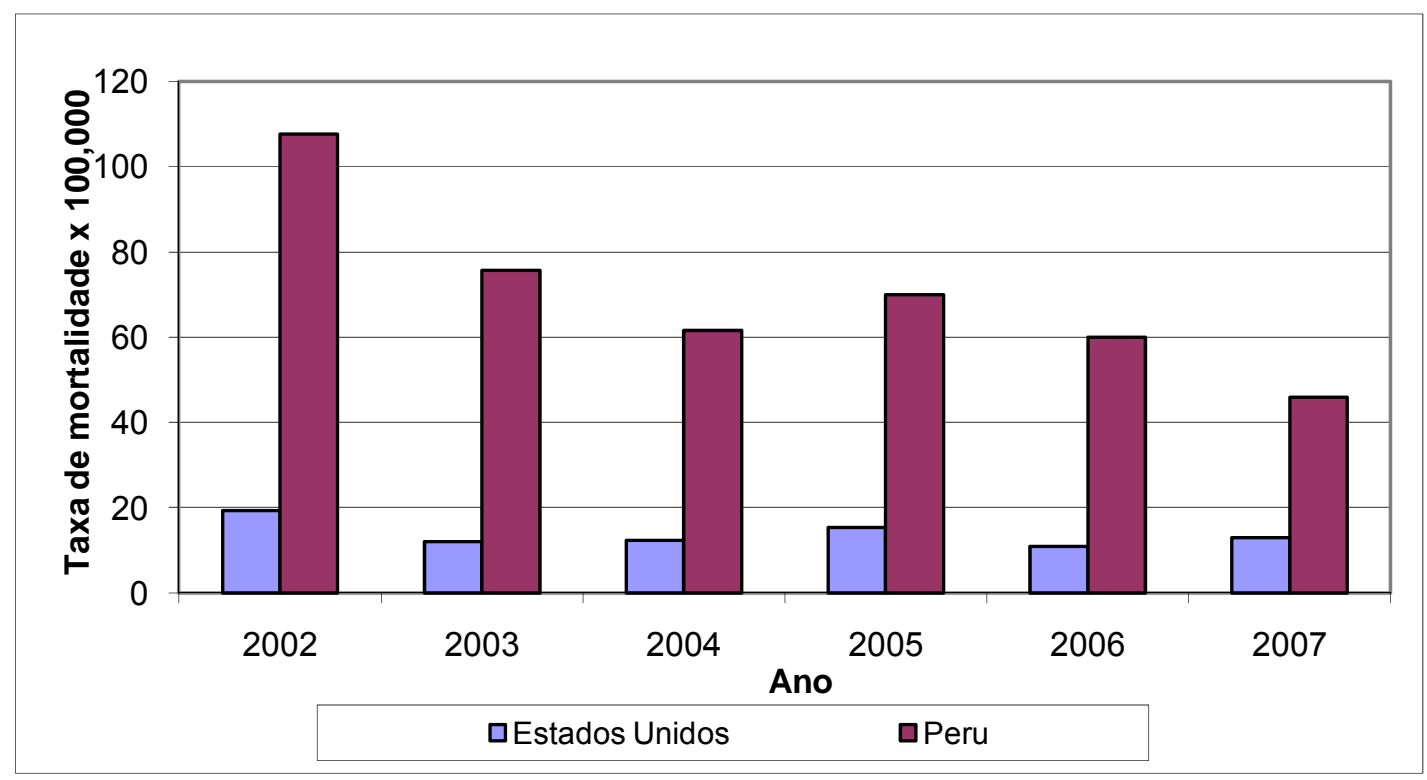

Figura 4.4 - Comparativo da taxa de mortalidade na mineração metálica e não metálica entre USA e Peru de 2002 a 2007 (MSHA, 2010)

A Tabela 4.3 mostra o número de acidentes fatais segundo o tipo. Pode-se observar que na mineração peruana, para o período compreendido entre 2000 e 2007 a queda de rochas constitui o tipo de acidente mais representativo com $36,79 \%$ das ocorrências ou 163 acidentes fatais, seguidos pela queda de pessoas e o tráfego de veículos com $11,06 \%$ e $9,06 \%$ respectivamente; os restantes $43,12 \%$ dos acidentes fatais correspondem aos outros tipos de acidentes (PERU, 2008a).

\footnotetext{
${ }^{13} \mathrm{O}$ presente estudo foi feito abordando o setor da mineração, no entanto é possivel que outros setores economicos apresentem taxas de mortalidade ainda maiores, isto devido à alta taxa de subnotificação ou à situação de informalidade em alguns setores economicos peruanos.
} 
Tabela 4.3 - Número de ocorrências com óbito na mineração do Peru segundo o tipo de acidente

\begin{tabular}{|c|c|c|c|c|c|c|c|c|c|c|}
\hline Tipo de acidente & ষ্ণ & $\bar{\sim}$ & ণ̃ & ஜ & ষ্ণ & 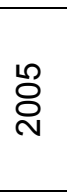 & 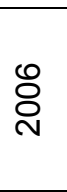 & 옹 & $\begin{array}{l}\bar{\pi} \\
\stackrel{0}{0}\end{array}$ & 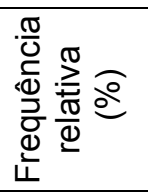 \\
\hline Queda de rochas & 19 & 27 & 28 & 21 & 14 & 25 & 15 & 14 & 163 & 36,79 \\
\hline Escorregamento de taludes & 1 & 2 & 2 & 1 & 7 & 4 & 5 & 7 & 29 & 6,55 \\
\hline Afogamento ou inundação & 0 & 0 & 0 & 0 & 0 & 1 & 0 & 0 & 1 & 0,23 \\
\hline Intoxicação e asfixia & 1 & 0 & 4 & 5 & 1 & 2 & 4 & 10 & 27 & 6,09 \\
\hline Tráfego de veículos & 5 & 5 & 5 & 4 & 4 & 5 & 6 & 6 & 40 & 9,03 \\
\hline Carregamento e transporte & 3 & 5 & 3 & 0 & 2 & 3 & 3 & 4 & 23 & 5,19 \\
\hline Manobra de equipamentos & 2 & 4 & 1 & 5 & 4 & 1 & 2 & 3 & 22 & 4,97 \\
\hline Enterramento por afundamento de terreno & 0 & 0 & 3 & 0 & 1 & 0 & 1 & 0 & 5 & 1,13 \\
\hline Manipulação de materiais & 1 & 2 & 2 & 0 & 0 & 0 & 1 & 3 & 9 & 2,03 \\
\hline Queda de pessoas & 7 & 9 & 8 & 5 & 4 & 7 & 4 & 5 & 49 & 11,06 \\
\hline Explosões & 6 & 1 & 3 & 3 & 2 & 1 & 3 & 2 & 21 & 4,74 \\
\hline Ferramentas & 1 & 0 & 0 & 0 & 0 & 0 & 0 & 1 & 2 & 0,45 \\
\hline Energia elétrica & 1 & 2 & 3 & 2 & 3 & 1 & 5 & 1 & 18 & 4,06 \\
\hline Outros & 1 & 5 & 2 & 3 & 8 & 5 & 7 & 3 & 34 & 7,67 \\
\hline Total & 48 & 62 & 64 & 49 & 50 & 55 & 56 & 59 & 443 & 100,00 \\
\hline
\end{tabular}

Fonte: (PERU, 2008a)

A Tabela 4.4 mostra o número de vítimas fatais de acidentes na mineração peruana, que aconteceram entre 2000 e 2007. Observa-se que nesse período aconteceu um total de 443 acidentes fatais com um resultado de 499 vítimas. Isso mostra que houve acidentes que causaram mais de uma vítima fatal. Pode-se observar ainda que no período estudado, os acidentes por queda de rochas representam $36,3 \%$ ou 181 vítimas fatais, seguidos pela queda de pessoas e pelo tráfego de veículos com $10,0 \%$ e $9,4 \%$ respectivamente. O restante de categorias é responsável por $44,3 \%$ das vítimas fatais.

Percebe-se ainda que as categorias de acidentes por queda de rochas ou de pessoas, tráfego de veículos, escorregamento de taludes, manobra de equipamentos, explosões e energia elétrica sempre aconteceram no período estudado.

A Tabela 4.5 mostra o número de acidentes fatais por tipo na mineração peruana de médio e grande porte que aconteceram durante 2007. Percebe-se que a queda de rochas continua sendo o tipo de acidente mais importante, representando $29,41 \%$ dos acidentes fatais ou ainda 15 acidentes com um saldo de 16 vítimas. Nesse ano, segundo o "Organismo Superior de la inversión em Energia y Mineria del Perú" (OSINERGMIN); além dos acidentes por queda de rochas, aqueles por asfixia e 
manobra de equipamentos seguem em importância com uma frequência relativa de $13,73 \%$ cada.

Tabela 4.4 - Número de vítimas fatais na mineração do Peru segundo o tipo de acidente

\begin{tabular}{|c|c|c|c|c|c|c|c|c|c|c|}
\hline TIPO DE ACIDENTE & 용 & ঠ্ঠি & ్ㅠ & 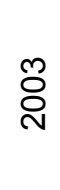 & ঠ & 용 & $\begin{array}{l}\text { O } \\
\text { ㅇ }\end{array}$ & 옹 & $\begin{array}{l}\overline{\widetilde{\sigma}} \\
\stackrel{\mathbb{0}}{ }\end{array}$ & 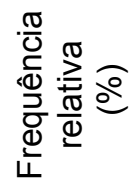 \\
\hline Queda de rochas & 20 & 30 & 32 & 22 & 15 & 31 & 17 & 14 & 181 & $36,3 \%$ \\
\hline Escorregamento de taludes & 2 & 2 & 2 & 1 & 9 & 6 & 7 & 8 & 37 & $7,4 \%$ \\
\hline Afogamento ou inundação & 0 & 0 & 0 & 0 & 0 & 2 & 0 & 0 & 2 & $0,4 \%$ \\
\hline Intoxicação e asfixia & 1 & 0 & 8 & 6 & 1 & 4 & 4 & 11 & 35 & $7,0 \%$ \\
\hline Tráfego de veículos & 6 & 5 & 6 & 7 & 5 & 5 & 6 & 7 & 47 & $9,4 \%$ \\
\hline Carregamento e transporte & 6 & 5 & 3 & 0 & 2 & 3 & 3 & 4 & 26 & $5,2 \%$ \\
\hline Manobra de equipamentos & 2 & 4 & 1 & 5 & 4 & 1 & 2 & 3 & 22 & $4,4 \%$ \\
\hline Enterramento por afundamento de terreno & 0 & 0 & 3 & 0 & 1 & 0 & 1 & 0 & 5 & $1,0 \%$ \\
\hline Manipulação de materiais & 1 & 2 & 2 & 0 & 0 & 0 & 1 & 3 & 9 & $1,8 \%$ \\
\hline Queda de pessoas & 7 & 10 & 8 & 5 & 4 & 7 & 4 & 5 & 50 & $10,0 \%$ \\
\hline Explosões & 6 & 1 & 3 & 3 & 2 & 1 & 5 & 2 & 23 & $4,6 \%$ \\
\hline Ferramentas & 1 & 0 & 0 & 0 & 0 & 0 & 0 & 1 & 2 & $0,4 \%$ \\
\hline Energia elétrica & 1 & 2 & 3 & 2 & 4 & 1 & 5 & 1 & 19 & $3,8 \%$ \\
\hline Outros & 1 & 5 & 2 & 3 & 9 & 8 & 10 & 3 & 41 & $8,2 \%$ \\
\hline Total & 54 & 66 & 73 & 54 & 56 & 69 & 65 & 62 & 499 & $100,0 \%$ \\
\hline
\end{tabular}

Fonte: (PERU, 2008a)

Tabela 4.5 - Número de acidentes fatais na grande e mediana mineração em 2007

\begin{tabular}{lcc}
\hline \multicolumn{1}{c}{ Tipo de acidente } & Frequência absoluta & Frequência relativa \\
\hline Queda de rochas & 15 & 29,41 \\
Asfixia & 7 & 13,73 \\
Manobra de equipamentos & 7 & 13,73 \\
Carregamento e transporte & 4 & 7,84 \\
Queda de pessoas & 4 & 7,84 \\
Manipulação de materiais & 3 & 5,88 \\
Trânsito & 3 & 5,88 \\
Intoxicação & 2 & 3,92 \\
Explosões & 2 & 3,92 \\
Outros & 2 & 3,92 \\
Escorregamento de terreno & 1 & 1,96 \\
Energia elétrica & 1 & 1,96 \\
\hline TOTAL & 51 & 100,00 \\
\hline
\end{tabular}




\subsection{CARACTERÍSTICAS PESSOAIS DAS VÍTIMAS FATAIS EM ACIDENTES POR QUEDA DE ROCHAS}

A Figura 4.5 mostra a distribuição da faixa etária das vítimas fatais em acidentes por queda de rochas. A média da idade das vítimas fatais é de 32,88 anos com um desvio padrão de 8,34 anos. Embora não exista uma informação precisa sobre a distribuição da faixa etária da população de trabalhadores na mineração peruana, em visita feita pelo autor a uma mina subterrânea peruana, a partir de uma amostragem de um grupo de 60 trabalhadores envolvidos em operações de lavra, observou-se que a idade média é de 32,92 anos e um desvio padrão de 6,95 anos conforme é mostrado no Apêndice E. Isto pode ser explicado porque as empresas mineiras geralmente optam por contratar trabalhadores novos, dispostos a assumir trabalhos considerados de alto risco.

Por outro lado, 62,5\% das vítimas fatais tinham um período de experiência de trabalho na mineração de 3 a 15 anos, enquanto que 37,50\% tinham experiência inferior a 3 anos como mostra a Figura 4.6. A média da experiência em mineração das vítimas fatais é de 5,22 anos, com um desvio padrão de 4,08 anos. O autor verificou também a partir de uma amostra de 60 trabalhadores envolvidos em operações de lavra subterrânea que a média de experiência é de 8,10 anos, com um desvio padrão de 6,40 anos conforme mostrado no Apêndice $E$.

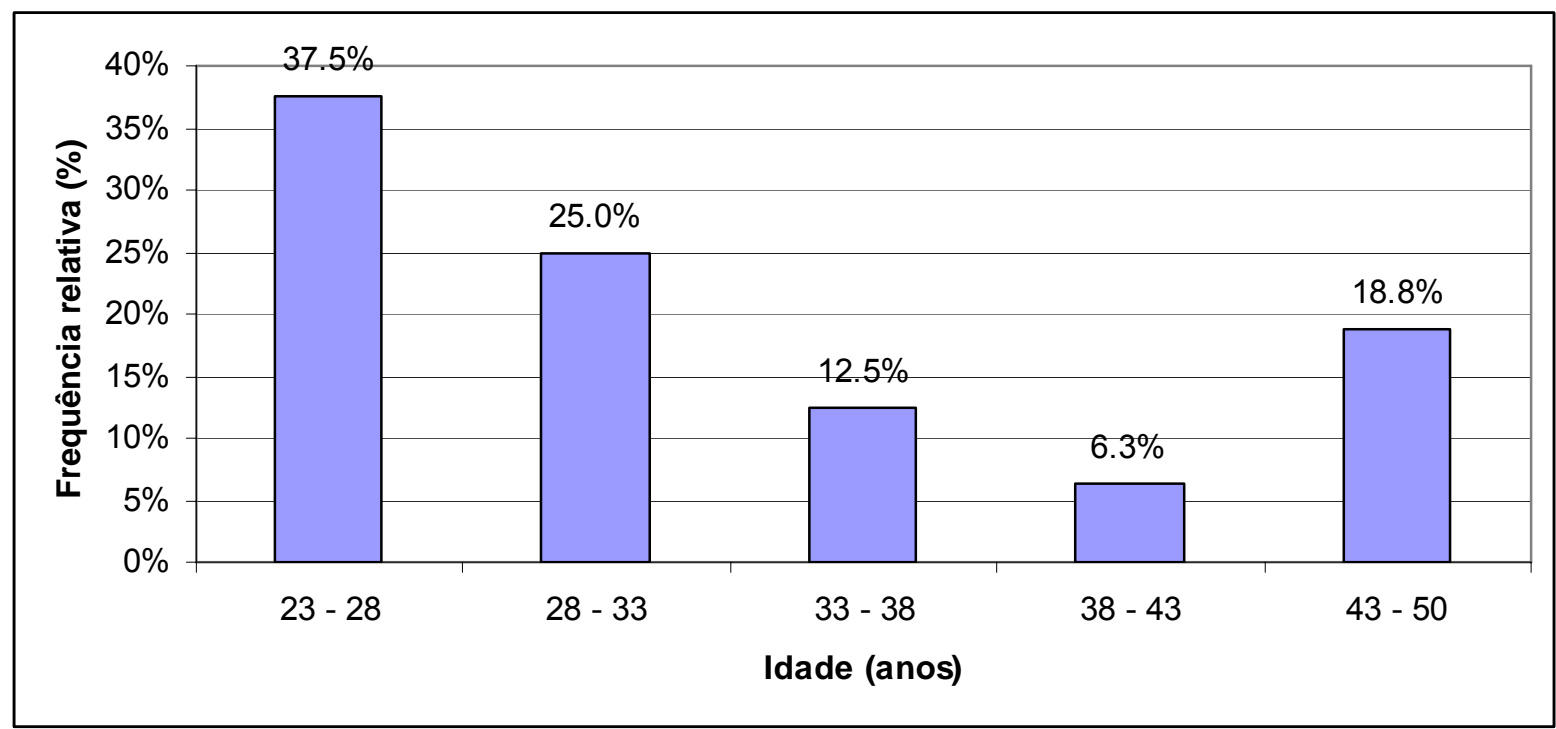

Figura 4.5 - Faixa etária de vítimas fatais em acidentes por queda de rochas no ano de 2007. 


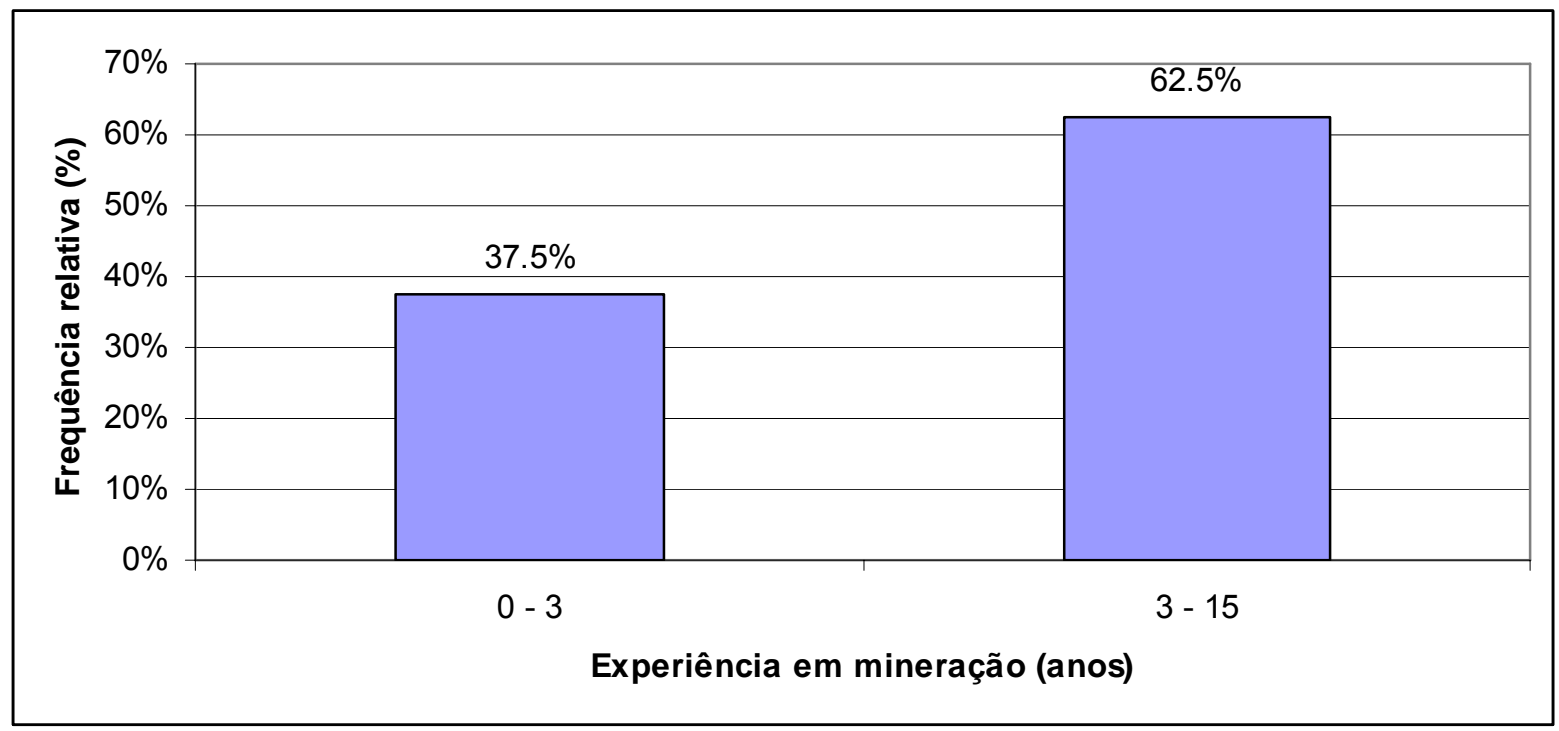

Figura 4.6 - Distribuição de frequências da experiência em mineração das vítimas fatais em acidentes por queda de rochas em 2007.

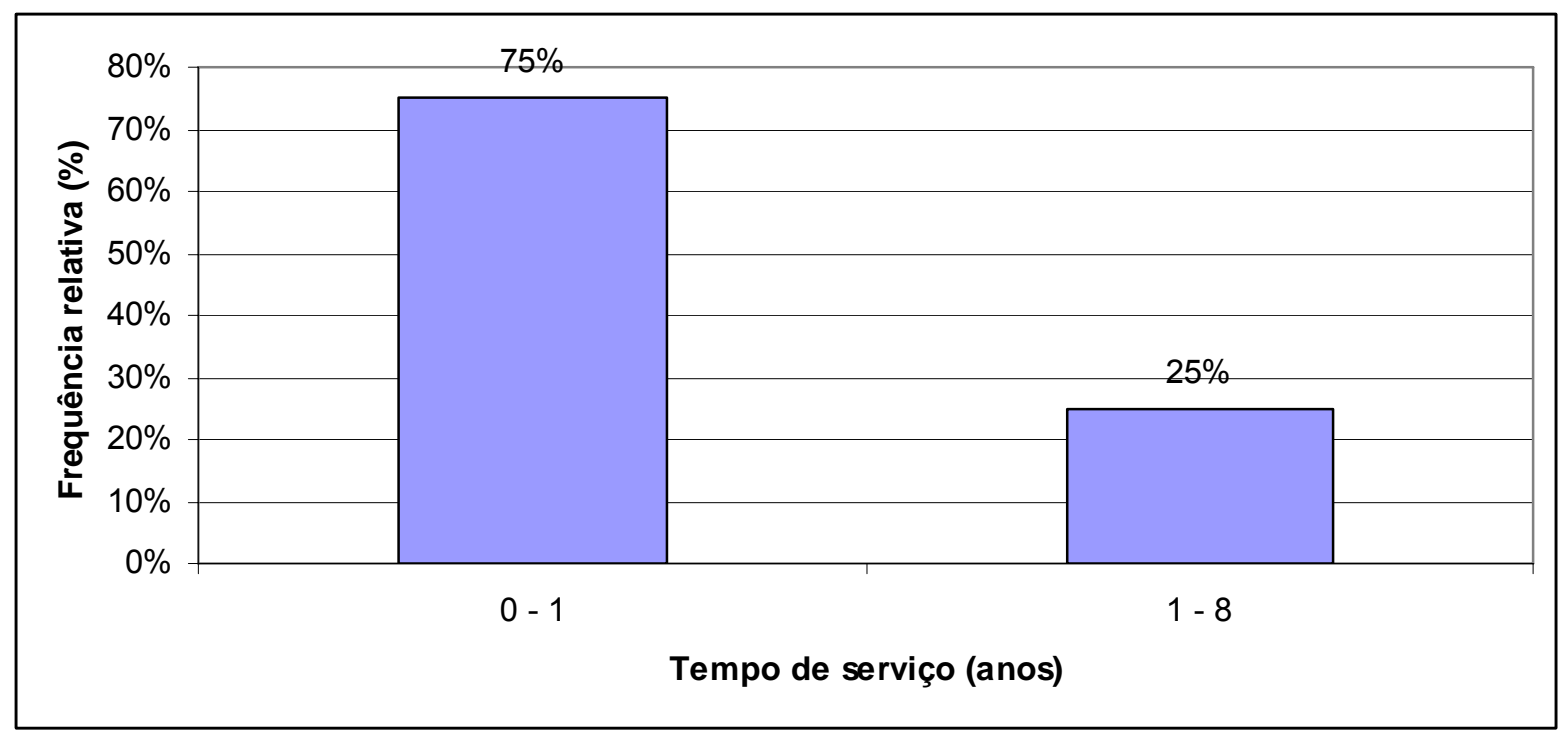

Figura 4.7 - Distribuição de frequências de tempo de serviço de vítimas fatais em acidentes por queda de rochas no ano 2007.

Finalmente, $75 \%$ das vítimas fatais por queda de rochas tinham um tempo de serviço menor que um ano enquanto que $25 \%$ tinham um tempo de serviço maior que um ano na mina onde aconteceu o acidente conforme mostrado na Figura 4.7. A média 
do tempo de serviço na mina onde a vítima sofreu o acidente fatal é de 1,18 anos, com um desvio padrão de 1,88 anos. O autor verificou também em visita a uma mina subterrânea, que a média do tempo de serviço é de 5,37 anos e um desvio padrão de 4,44 anos conforme mostrado no Apêndice E.

Da análise dos diagramas de dispersão mostrados nas Figuras 4.8 a 4.10, pode-se ver que não existe correspondência entre as variáveis analisadas. A Tabela 4.6 mostra ainda que a correlação entre as variáveis idade e experiência em mineração; assim como idade e tempo de serviço são pouco significativas sob o ponto de vista estatístico (correlação de Pearson maior do que 0,05 ) ou seja, não existe correlação linear entre as variáveis analisadas ${ }^{14}$.

Tabela 4.6 - Correlação entre idade, tempo de serviço e experiência em mineração das vítimas de acidentes por queda de rochas em 2007.

\begin{tabular}{llc}
\hline & & Idade \\
\hline \multirow{2}{*}{ Idade } & Correlação de Pearson & 1 \\
& Covariância & 69,58 \\
& $\mathrm{~N}$ & 16 \\
\hline \multirow{2}{*}{ Tempo de serviço em mina } & Correlação de Pearson & $-0,09$ \\
& Covariância & $-1,39$ \\
\hline \multirow{2}{*}{ Experiência em mineração } & $\mathrm{N}$ & 16 \\
& Correlação de Pearson & $0,502^{*}$ \\
& Covariância & 17,09 \\
\hline
\end{tabular}

* A correlação é significativa ao nível de 0,05 (bilateral).

\footnotetext{
${ }^{14}$ A aplicação de MRL para variáveis com coeficientes de correlação alto, pode gerar modelos não muito confiáveis (Silva, 1995).
} 


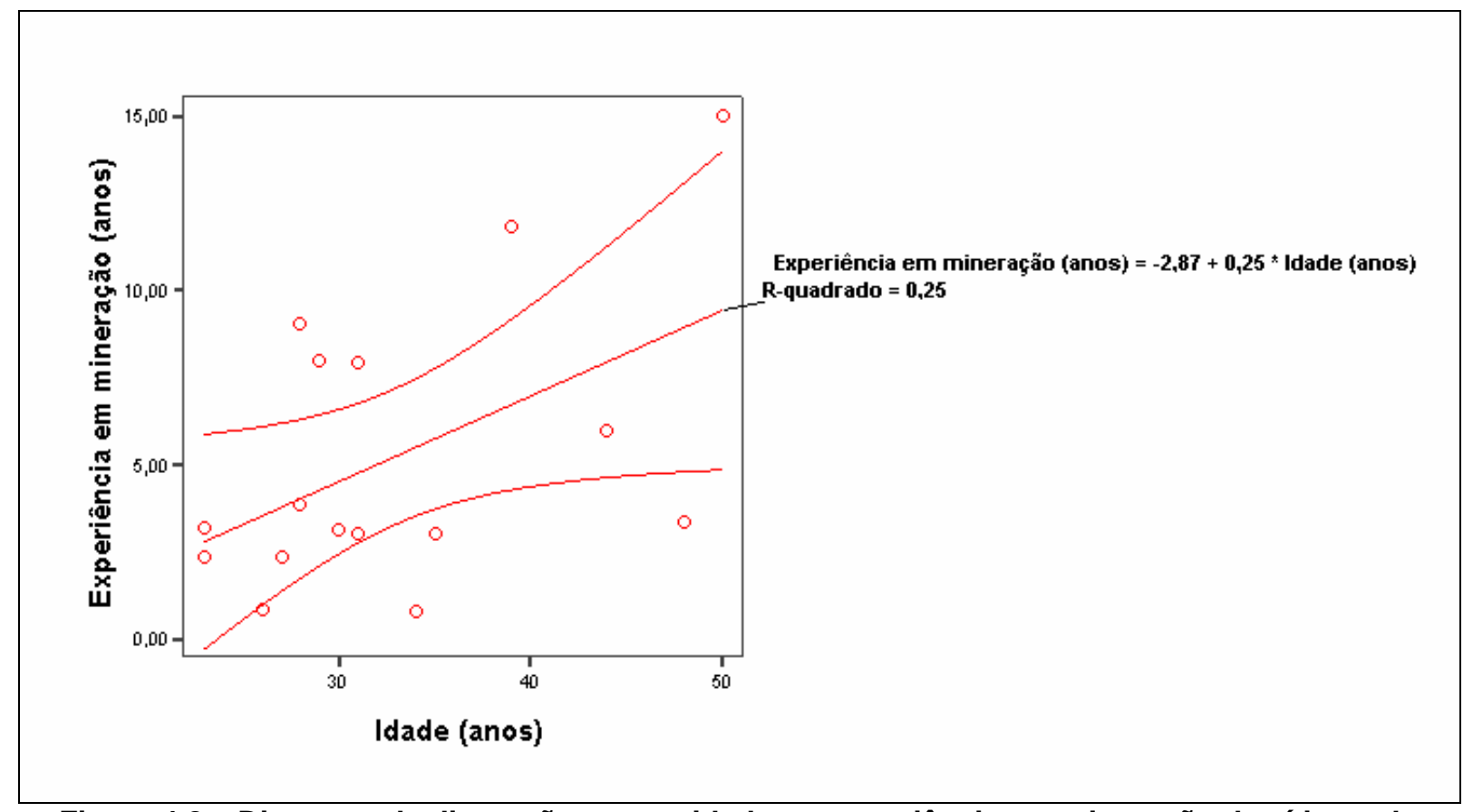

Figura 4.8 - Diagrama de dispersão entre a idade e a experiência em mineração de vítimas de acidentes por queda de rochas no ano 2007.

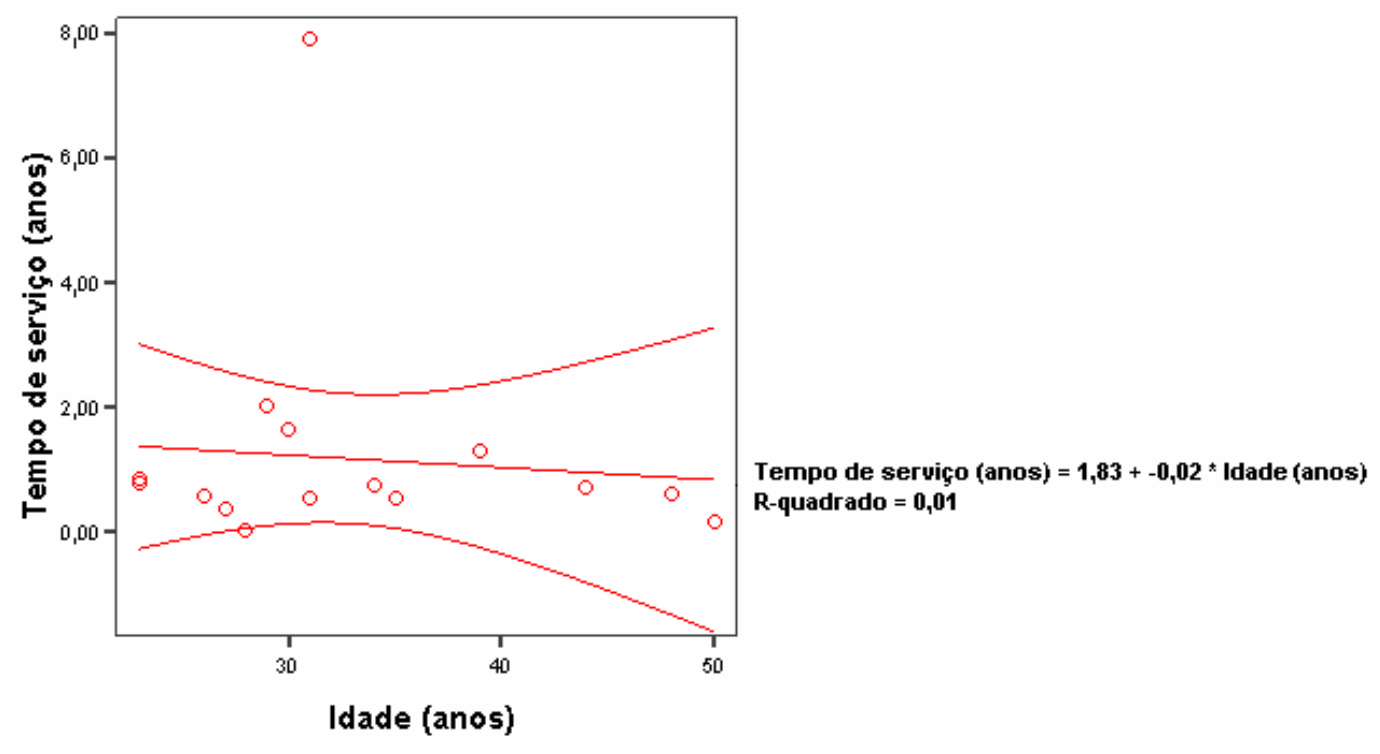

Figura 4.9 - Diagrama de dispersão entre a idade e o tempo de serviço de vítimas de acidentes por queda de rochas em 2007. 


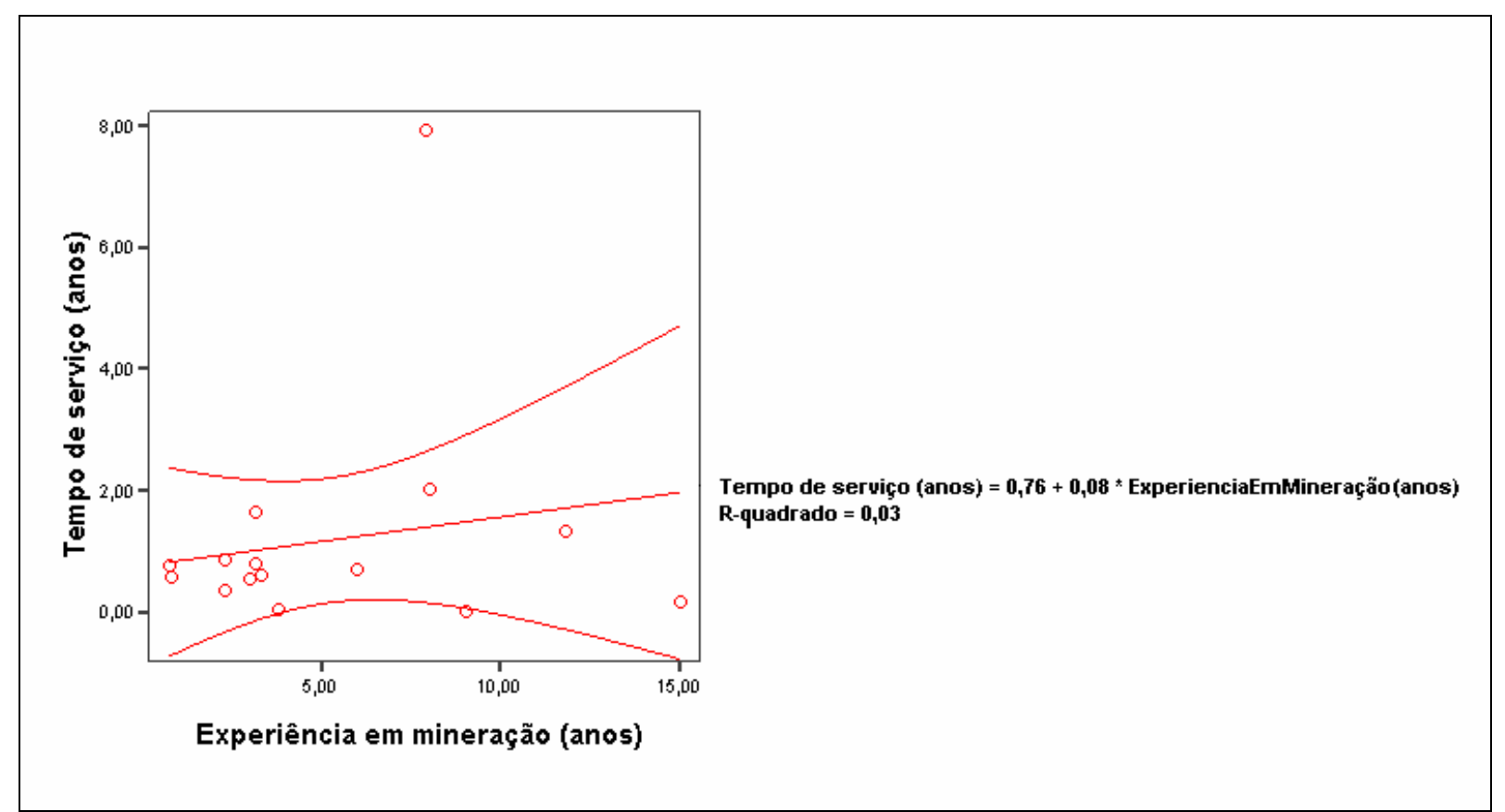

Figura 4.10 - Diagrama de dispersão entre experiência em mineração e o tempo de serviço de vítimas de acidentes por queda de rochas em 2007.

A Figura 4.11 mostra a frequência relativa das vítimas fatais segundo o grau de escolaridade. Percebe-se que $75 \%$ das vítimas fatais tinham uma escolaridade de ensino médio, seguido por $12,5 \%$ com escolaridade de nível superior e $6,25 \%$ com escolaridade de ensino fundamental e técnico superior cada. Isto se deve ao fato de a maioria das empresas mineiras como as especializadas (empreiteiras) exigerem no mínimo uma escolaridade de ensino médio no momento da contratação, assim, a maioria da população de trabalhadores em atividades operacionais de lavra (ajudantes, manobristas de perfuratriz, auxiliar de perfuração e desmonte, entre outros) tem ensino médio, o que se reflete também na maior quantidade de vítimas com este nível de escolaridade. 


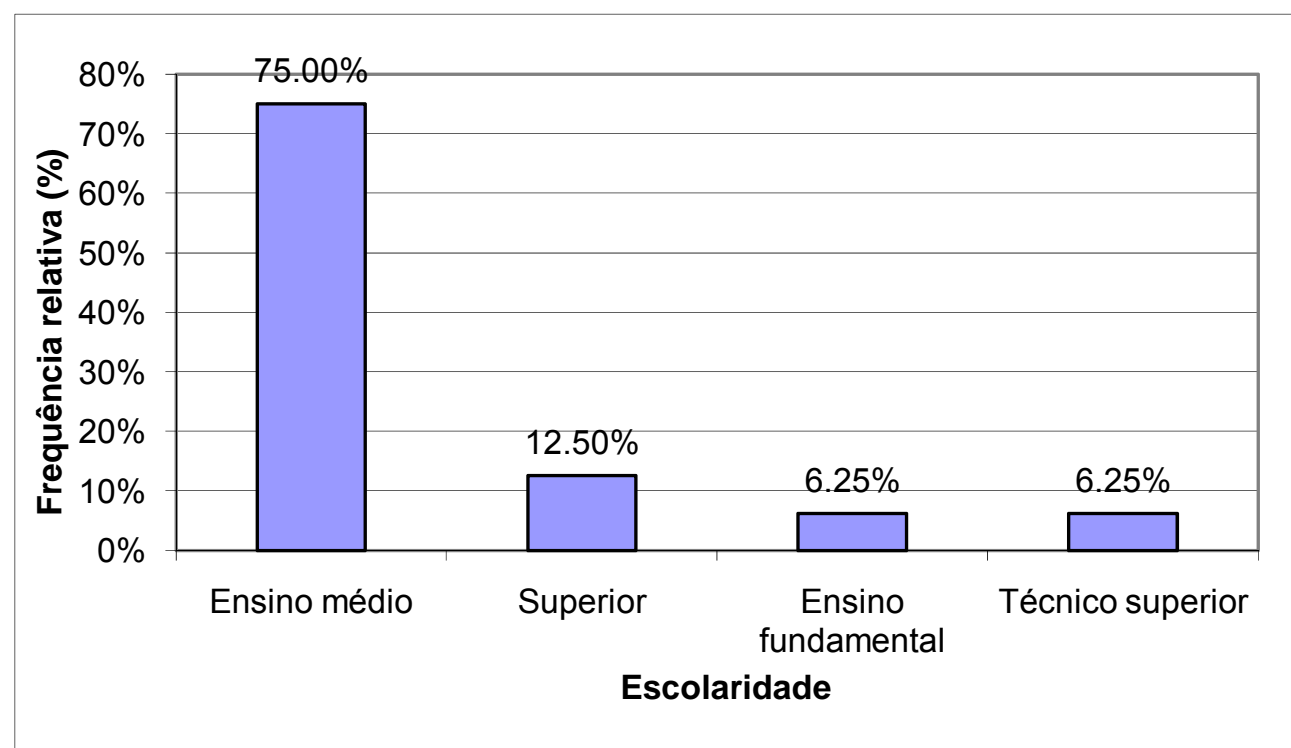

Figura 4.11 - Frequência relativa da escolaridade das vítimas fatais de acidentes por queda de rochas no ano de 2007.

A Figura 4.12 mostra a frequência relativa da ocupação das vítimas fatais. Percebe-se que os trabalhadores que desempenham a função de ajudante de perfuração sofrem o maior número de fatalidades atingindo $31,25 \%$ seguido pelos trabalhadores que desempenham a função de operadores de perfuratriz e serviço geral com percentuais de $18,50 \%$. Isso ocorre porque após detonação e retirada do material desmontado na frente de lavra, as tarefas de limpeza de rocha solta assim como a colocação de suporte artificial geralmente é desenvolvido pela própria equipe que incumbe-se das tarefas de perfuração da produção, o que os expõe a um risco maior. 


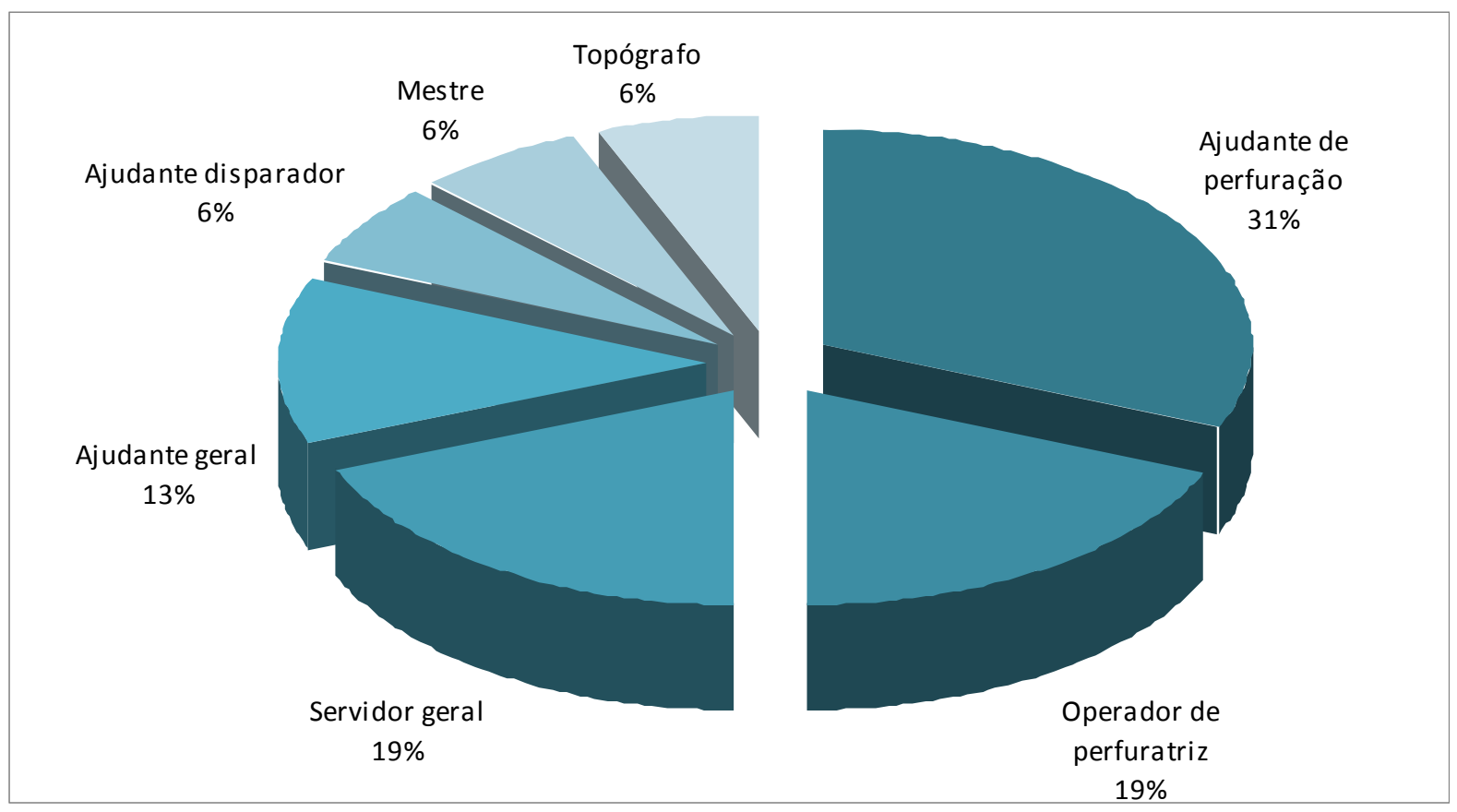

Figura 4.12 - Frequência relativa de vítimas fatais em acidentes por queda de rochas segundo a ocupação no ano 2007.

A Figura 4.13 mostra a frequência relativa das vítimas fatais segundo o vínculo de trabalho. Percebe-se que $75 \%$ das vítimas pertenciam a empresas especializadas prestadoras de serviço (empreiteiras), sendo que os $25 \%$ restantes pertencem à empresa mineira proprietária da mina. Isso se deve ao fato de que, na mineração peruana, a maior parte das operações unitárias de lavra, assim como as operações auxiliares, está terceirizada.

Além da forte terceirização, a falta de integração ou adoção da cultura organizacional por parte da empresa contratada dificulta a adoção e implementação de boas práticas de gestão de segurança da empresa contratante. Isso é ainda mais crítico em empresas em que as gerências da empresa mineira propriamente dita não estão realmente comprometidas com a melhoria do desempenho da segurança na organização, ou mesmo em empresas que cinicamente responsabilizam as empresas terceirizadas pelas questões de segurança sem integrá-las no sistema como um todo. 


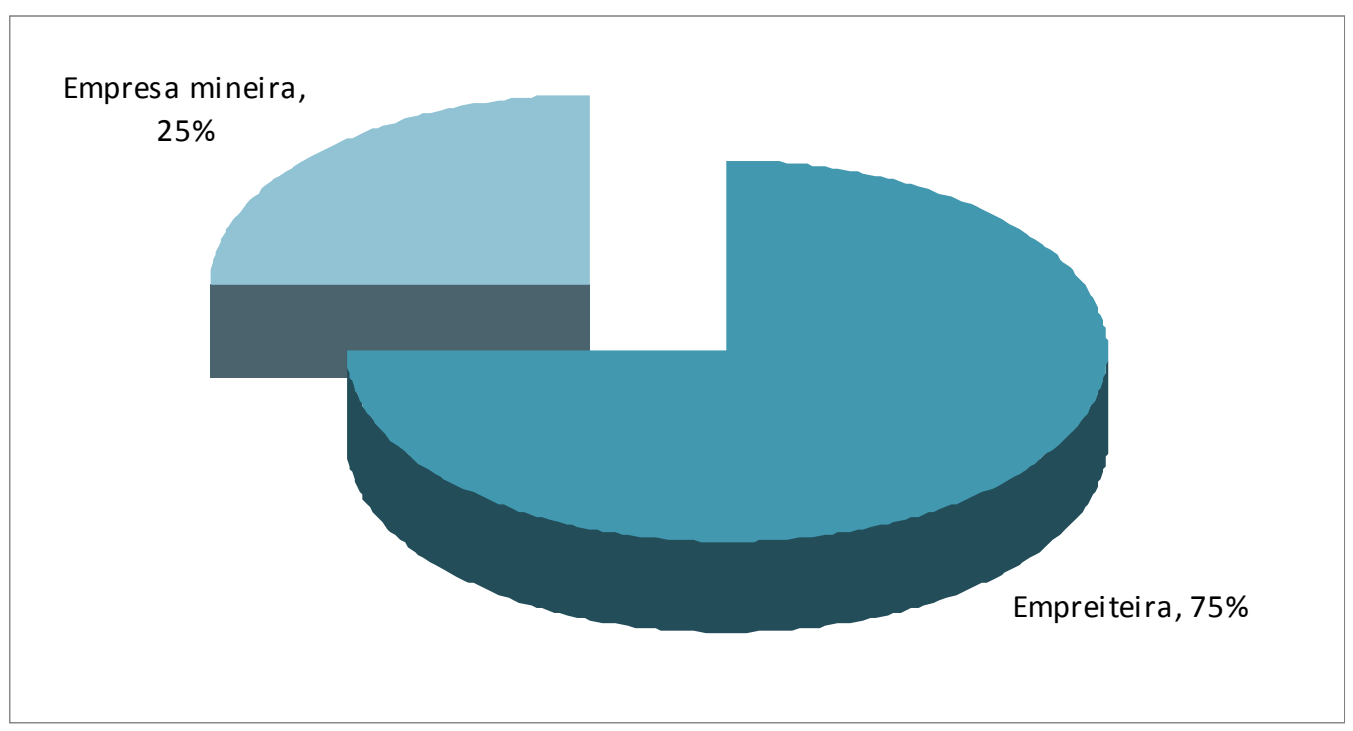

Figura 4.13 - Frequência relativa de vítimas fatais em acidentes por queda de rochas segundo vínculo empregatício em 2007.

A Figura 4.14 mostra a frequência relativa das vítimas fatais em acidentes por queda de rochas segundo o tipo de lesão que levou à morte. Percebe-se que $75 \%$ das mortes foram causadas por traumatismo múltiplo com envolvimento do tórax, abdome, parte inferior do dorso e pelve; que causaram danos morfológicos, fisiológicos e/ou bioquímicos resultando em mortes. O traumatismo encéfalo-craniano, também chamado como lesão cerebral é responsável por $19 \%$ das fatalidades. Os $6 \%$ restantes são causados pela combinação do traumatismo encéfalo-craniano com o traumatismo múltiplo.

Da análise dos relatórios de acidentes que apresentam como informação as dimensões dos blocos de rochas que caíram e causaram as fatalidades pode-se observar que estes têm um peso médio aproximado de três toneladas, mostrando sua enorme potencialidade de causar acidentes com danos bastante significativos tanto para os trabalhadores, caracterizado pela fragilidade e vulnerabilidade da anatomia humana, quanto para os equipamentos utilizados na lavra. 


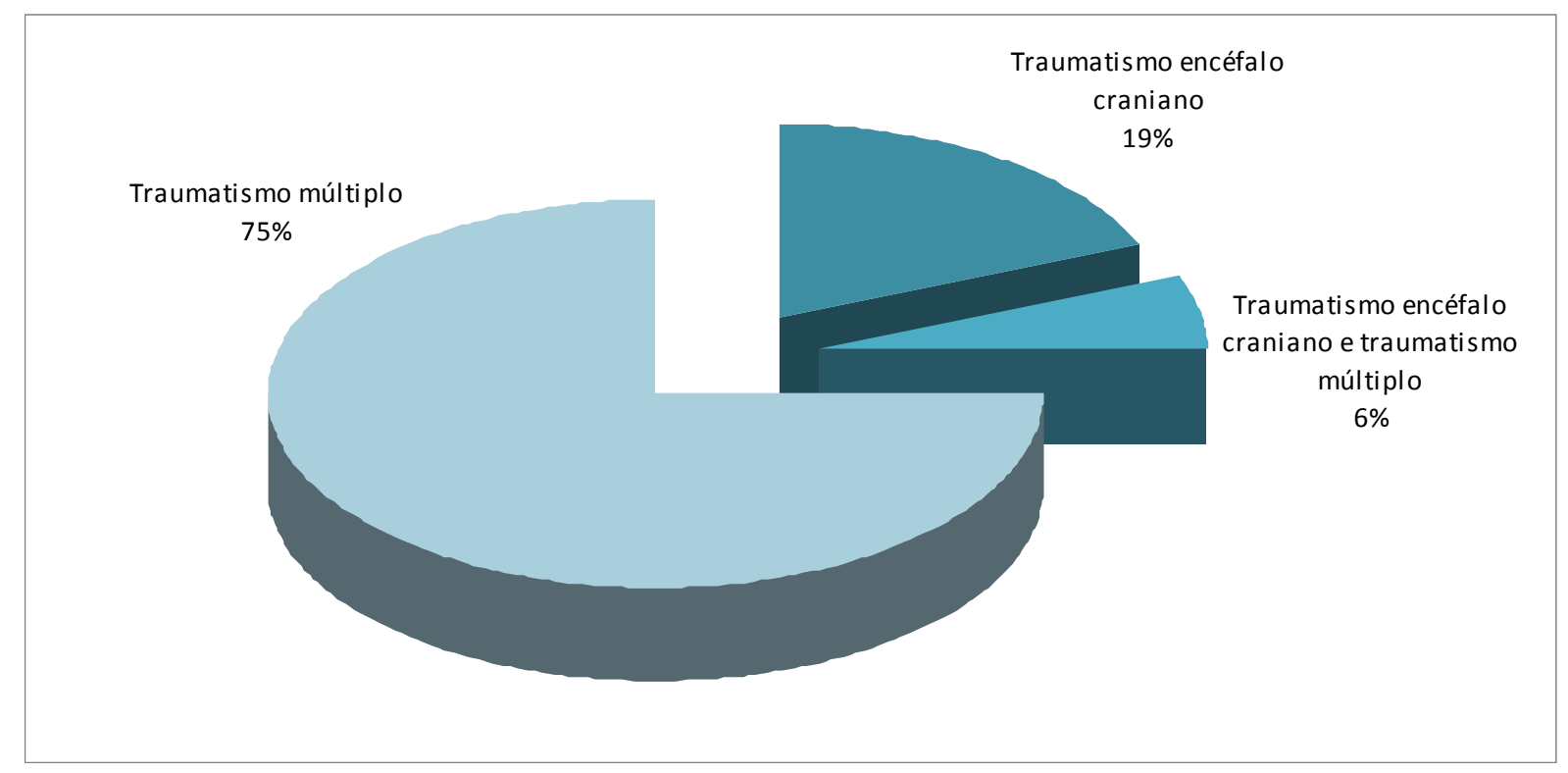

Figura 4.14 - Frequência relativa de vítimas fatais segundo o tipo de lesão

\subsection{MODELAGEM DO RISCO DE ACIDENTABILIDADE POR QUEDA DE ROCHAS}

A partir dos relatórios de acidentes disponibilizado pela "Oficina de Fiscalización Minera del Organismo Superior de la Inversión en Energia y Mineria del Peru OSINERGMIN" (Anexo A) foi gerada uma base de dados no formato Excel ${ }^{\circledR}$ (Apêndice B). Esta base de dados compreende as informações referentes às características pessoais (idade, experiência, tempo de serviço, ocupação ou função, vínculo empregatício, estado civil, entre outros) das 54 vítimas fatais resultantes dos 51 acidentes que aconteceram na mineração de grande e medio porte durante o de 2007; assim como as informações referentes ao acidente (tipo de acidente, local do acidente, mina e empresa mineira onde aconteceu o acidente, tipo de mineração, causas fundamentais e imediatas, entre outros).

Após a exclusão dos acidentes que aconteceram na mineração a céu aberto, assim como em atividades de beneficiamento e embarque, foi feita uma recodificação das características pessoais das vítimas, tendo como pressuposto o fato de que o modelo gerado foi parcimonioso (modelo simples) conforme mostrado na Tabela 4.7. $\mathrm{O}$ critério adotado para a categorização (codificação) das variáveis é que a característica 
estudada tem que ter pelo menos uma frequência relativa de $10 \%$.

Os acidentes ocorridos na mineração subterrânea do Peru no ano 2007 foram de vários tipos. Dessa maneira, a variável "Tipo de acidente" apresentou uma dicotomia, de forma que quando o acidente foi provocado por queda de rochas esta foi codificada como "1" e quando o acidente for de outro tipo foi codificada como "0".

A faixa etária das vítimas fatais em acidentes na mineração subterrânea estava compreendida entre 19 e 50 anos, com uma média de 31,02 anos e um desvio padrão de 7,96 anos. Assim, a variável "Idade" foi codificada em três categorias: "0" quando a idade do trabalhador estava compreendida entre 18 e 30 anos, "1" quando a idade estava compreendida entre 30 e 40 anos e "2" quando a idade oscilava entre 40 e 50 anos.

O tempo de serviço das vítimas fatais em acidentes em mineração subterrânea variava entre um dia e 8,25 anos, com uma média de 1,07 anos e um desvio padrão de 1,77 anos. Dessa maneira, a variável "Tempo de serviço" apresentou a seguinte dicotomia: a categoria "0" foi usada quando o tempo de serviço na mina onde aconteceu o acidente era inferior a um ano e a categoria "1" quando o tempo de serviço era superior a um ano.

A experiência das vítimas fatais na mineração subterrânea peruana estava compreendida entre 0,12 e 20 anos, com uma média de 4,95 anos e um desvio padrão de 4,42 anos. Assim, a variável "Experiência em mineração" foi codificada em duas categorias: "0" quando a experiência era inferior a três anos (trabalhadores inexperientes) e "1" quando o trabalhador tinha uma experiência maior a três anos (trabalhadores experientes).

A frequência relativa das vítimas fatais segundo o estado civil, na mineração subterrânea, estava distribuída da seguinte forma: 25\% das vítimas eram solteiros enquanto que $75 \%$ eram casados ou conviventes. Assim, a variável "Estado civil" foi codificada em duas categorias: "0" quando o estado civil era solteiro e "1" quando era casado ou convivente.

A escolaridade das vítimas fatais na mineração subterrânea estava distribuída da seguinte forma: 10,4\% tinham ensino fundamental, $75 \%$ ensino médio e $14,6 \%$ apresentavam escolaridade superior técnica ou universitária. Assim, a variável 
"escolaridade" foi codificada em três categorias: "0" quando a escolaridade era ensino fundamental, "1" para escolaridade de ensino médio e "2" tanto para o ensino superior técnico quanto para o universitário.

As ocupações ou funções que desempenhavam as vítimas fatais na mineração subterrânea eram diversas (ajudantes, servidores gerais, eletricistas, manobristas e operadores, chefes de turno, motoristas, mestres, entre outros). Partindo do pressuposto de que geralmente a função de ajudantes e servidores gerais são desenvolvidas por trabalhadores novos e inexperientes, A variável "Ocupação" foi codificada em duas categorias: "0" para a ocupação ou função de ajudantes e servidores gerais, e "1" para outras ocupações ou funções. A frequência relativa no quadro geral de acidentes em mineração subterrânea, segundo essas duas categorias, era: $41,7 \%$ ajudantes e servidores gerais e $58 \%$ outras ocupações ou funções.

Tabela 4.7 - Recodificação das variáveis para seu uso na geração do MRL

\begin{tabular}{|c|c|c|}
\hline Variável & Código & Característica \\
\hline \multirow{3}{*}{ Tipo de acidente } & 1 & Acidente por queda de rochas \\
\hline & 0 & Acidente por outra causa \\
\hline & 0 & Idade do trabalhador (anos) $\in[18,30)$ \\
\hline \multirow[t]{2}{*}{ Idade } & 1 & Idade do trabalhador (anos) $\in[30,40)$ \\
\hline & 2 & Idade do trabalhador (anos) $\in[40,50)$ \\
\hline \multirow{2}{*}{ Tempo de serviço } & 0 & Tempo de serviço (anos) $\in[0,1)$ \\
\hline & 1 & Tempo de serviço (anos) $\in[1,9)$ \\
\hline \multirow{2}{*}{ Experiência em mineração } & 0 & Experiência em mineração (anos) $\in[0,3)$ \\
\hline & 1 & Experiência em mineração (anos) $\in[3,20)$ \\
\hline \multirow{3}{*}{ Estado civil } & 0 & Solteiro \\
\hline & 1 & Casado e convivente \\
\hline & 0 & Ensino fundamental \\
\hline \multirow[t]{2}{*}{ Escolaridade } & 1 & Ensino médio \\
\hline & 2 & Superior técnico e/ou universitário \\
\hline \multirow{2}{*}{ Ocupação } & 0 & Ajudante \\
\hline & 1 & Não ajudante \\
\hline \multirow{2}{*}{ Vínculo empregatício } & 0 & Empresa terceirizada \\
\hline & 1 & Empresa mineira \\
\hline
\end{tabular}

A Tabela 4.8 mostra as variáveis $\operatorname{codificadas~}^{15}$, a mesma que foi utilizada como a matriz de entrada (Input) para a elaboração do modelo matemático no programa SPSS ${ }^{\circledR}$.

15 Para diferentes cortes (intervalos) os resultados dos parâmetros estimados através da RL são diferentes. Contudo, no processo de modelagem procura-se cumprir com algumas restrições que a aplicação da metodologia impõe, por exemplo, que uma das categorias da variável tenha pelo menos 10 casos. 
Tabela 4.8 - Matriz de entrada recodificada para a geração do modelo de regressão logística

\begin{tabular}{|c|c|c|c|c|c|c|c|c|}
\hline 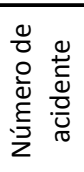 & 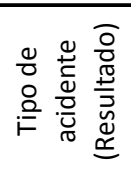 & $\begin{array}{l}\frac{0}{0} \\
\frac{\pi}{0} \\
\text { On }\end{array}$ & 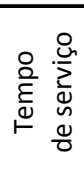 & 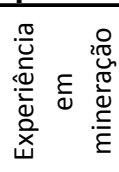 & 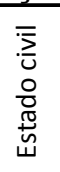 & $\begin{array}{l}\frac{0}{0} \\
\frac{\pi}{0} \\
\frac{0}{5} \\
\frac{\pi}{0} \\
\\
\tilde{u}\end{array}$ & 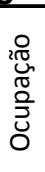 & 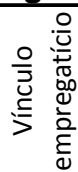 \\
\hline 1 & 0 & 0 & 0 & 0 & 1 & 1 & 0 & 0 \\
\hline 2 & 1 & 0 & 0 & 0 & 1 & 1 & 0 & 0 \\
\hline 3 & 0 & 2 & 0 & 1 & 1 & 2 & 1 & 1 \\
\hline 4 & 0 & 0 & 0 & 0 & 1 & 2 & 1 & 0 \\
\hline 5 & 0 & 1 & 1 & 1 & 1 & 1 & 1 & 0 \\
\hline 6 & 1 & 2 & 0 & 1 & 1 & 2 & 1 & 0 \\
\hline 7 & 0 & 0 & 0 & 0 & 0 & 1 & 1 & 0 \\
\hline 8 & 0 & 1 & 0 & 1 & 1 & 1 & 1 & 1 \\
\hline 9 & 0 & 0 & 0 & 0 & 1 & 1 & 1 & 0 \\
\hline 10 & 1 & 0 & 1 & 1 & 0 & 2 & 0 & 1 \\
\hline 11 & 1 & 2 & 0 & 1 & 1 & 0 & 1 & 0 \\
\hline 12 & 0 & 1 & 1 & 1 & 1 & 1 & 1 & 0 \\
\hline 13 & 0 & 0 & 0 & 0 & 0 & 2 & 1 & 0 \\
\hline 14 & 0 & 0 & 0 & 1 & 1 & 2 & 1 & 0 \\
\hline 14 & 0 & 0 & 0 & 1 & 1 & 1 & 1 & 0 \\
\hline 15 & 0 & 1 & 0 & 1 & 1 & 0 & 1 & 0 \\
\hline 16 & 0 & 0 & 1 & 1 & 0 & 0 & 1 & 0 \\
\hline 17 & 0 & 0 & 0 & 0 & 0 & 1 & 0 & 0 \\
\hline 18 & 0 & 2 & 0 & 1 & 1 & 1 & 1 & 0 \\
\hline 19 & 0 & 0 & 1 & 0 & 1 & 1 & 1 & 0 \\
\hline 20 & 0 & 1 & 0 & 1 & 1 & 1 & 1 & 0 \\
\hline 21 & 1 & 1 & 0 & 0 & 1 & 1 & 0 & 0 \\
\hline 22 & 0 & 0 & 0 & 0 & 1 & 1 & 1 & 0 \\
\hline 23 & 0 & 1 & 0 & 1 & 1 & 1 & 0 & 1 \\
\hline 25 & 0 & 1 & 0 & 0 & 1 & 1 & 1 & 0 \\
\hline 26 & 0 & 1 & 0 & 1 & 0 & 1 & 1 & 1 \\
\hline 27 & 0 & 0 & 0 & 0 & 1 & 1 & 0 & 0 \\
\hline 28 & 0 & 1 & 0 & 0 & 1 & 1 & 0 & 0 \\
\hline 28 & 0 & 0 & 1 & 0 & 0 & 1 & 0 & 0 \\
\hline 29 & 1 & 1 & 0 & 0 & 1 & 1 & 0 & 0 \\
\hline 30 & 0 & 0 & 0 & 0 & 1 & 1 & 1 & 0 \\
\hline 31 & 0 & 2 & 1 & 1 & 1 & 0 & 1 & 0 \\
\hline 32 & 0 & 0 & 1 & 0 & 0 & 1 & 1 & 0 \\
\hline 33 & 1 & 0 & 0 & 1 & 1 & 1 & 0 & 1 \\
\hline 34 & 1 & 0 & 0 & 0 & 1 & 1 & 0 & 1 \\
\hline 35 & 1 & 1 & 1 & 1 & 1 & 1 & 1 & 0 \\
\hline 37 & 1 & 0 & 0 & 0 & 1 & 2 & 0 & 0 \\
\hline 39 & 0 & 0 & 0 & 0 & 0 & 1 & 0 & 0 \\
\hline 40 & 0 & 0 & 0 & 0 & 0 & 1 & 0 & 0 \\
\hline 41 & 1 & 0 & 0 & 1 & 1 & 1 & 0 & 0 \\
\hline 41 & 1 & 2 & 0 & 1 & 1 & 1 & 0 & 0 \\
\hline 43 & 1 & 0 & 0 & 1 & 1 & 1 & 1 & 0 \\
\hline 44 & 1 & 0 & 1 & 1 & 1 & 1 & 1 & 0 \\
\hline 46 & 0 & 1 & 1 & 1 & 1 & 1 & 1 & 1 \\
\hline 48 & 0 & 0 & 0 & 0 & 0 & 1 & 1 & 1 \\
\hline 49 & 0 & 1 & 0 & 1 & 1 & 0 & 0 & 0 \\
\hline 50 & 1 & 1 & 0 & 0 & 0 & 1 & 0 & 0 \\
\hline 51 & 1 & 1 & 1 & 1 & 1 & 1 & 0 & 1 \\
\hline
\end{tabular}


O tipo de acidente foi considerado como a variável dependente $Y$ (variável resposta) referido ao tipo de acidente que levou a vítima à fatalidade, de forma que os valores adotados foram de $Y=1$ quando a vítima fatal teve um acidente por queda de rochas e $Y=0$ se foi provocado por outro tipo de acidente diferente da queda de rochas.

$\mathrm{Na}$ procura por um modelo parcimonioso (modelo simples), existem vários procedimentos para eliminar as variáveis não significativas sob o ponto de vista estatístico. O mais usado é o da regressão passo a passo (step wise regression), que consiste em construir sucessivos modelos, de maneira que cada um seja diferente do precedente em uma variável só. Existem duas variantes do método de regressão passo a passo: o para frente (step up) e o para trás (step down), que consistem em sucessivas adições e eliminações de variáveis, respectivamente. Ainda existe um procedimento mais simples e direto, que é chamado de significações sucessivas, o mesmo que é usado neste trabalho. O procedimento consiste em (SILVA,1995):

- $\quad$ Gera-se o modelo com todas as variáveis;

- Identificam-se as variáveis cujos coeficientes são significativamente diferentes de 0 . Para isso, se utiliza o teste de Wald em cada passo. Se todas as variáveis são significativas se conclui o processo, caso contrário, toma-se o passo a seguir:

- $\quad$ Ajusta-se o modelo com as variáveis que foram significativas no passo anterior.

Numa primeira etapa, a partir da matriz de entrada mostrada na Tabela 4.8 e considerando-se todas as variáveis independentes, foram estimados os coeficientes do modelo, identificando-se as variáveis estatisticamente significativas.

Após exclusão das variáveis definidas como não significativas na primeira etapa ("Escolaridade", "Vínculo empregatício", "Tempo de serviço" e "Idade”), foram feitas as estimativas dos coeficientes do modelo conforme se mostra no Apêndice D. Nesta segunda etapa, pode-se observar que, além do intersecto, a variável "Estado civil" não é significativa.

Numa terceira etapa, estimam-se os parâmetros do modelo, os mesmos que se mostram no Apêndice D. Pode-se observar que nesta etapa, além do intersecto, tanto a variável "Ocupação" como "Experiência em mineração" são significativos sob o ponto de 
vista estatístico, pois o valor absoluto do teste de Wald ${ }^{16}$ é maior do que 1,96. A partir desta estimativa se estabelece a Equação matemática 4.1, que permite estimar a probabilidade de um trabalhador sofrer um acidente por queda de rochas em função das variáveis consideradas como sendo estatisticamente significativas ${ }^{17}$.

$$
P(Y=1)=\frac{1}{1+\exp (-1,119+2,477 \cdot O C-1,690 \cdot E M)}
$$

OC: Ocupação ou função; adota o valor unitário quando a ocupação for ajudante, caso contrário adota o valor zero.

EM: Experiência em mineração do trabalhador, adota o valor unitário quando a experiência do trabalhador for inferior a 3 anos, caso contrário adota o valor zero.

A partir da Equação genérica 4.1 e considerando as variáveis estatisticamente representativas, podem-se estabelecer quatro perfis possíveis e suas correspondentes equações específicas. Estas equações permitem calcular a probabilidades de sofrer acidentes por queda de rochas assim como suas correspondentes odds (chances) conforme se mostra na Tabela 4.9.

\footnotetext{
${ }^{16}$ A razão entre o coeficiente $b$ e seu respectivo desvio padrão (se) pode ser expressa através de $Z=b / s e(b)$. $Z$ segue uma distribuição normal padrão, de modo que, ao nível $\alpha=0,05$, só é necessário analisar se $|z|>1,96$. Neste caso, se declara que b é significativamente diferente de zero, este é denominado como o teste de Wald.

${ }^{17}$ Para diferentes valores de corte (intervalos) utilizados para a codificação, são obtidos valores diferentes dos parâmetros estimados. Contudo, a maioria dos modelos gerados, inclusive os gerados pelos métodos passo a passo (step wise regression) indicaram à função e à experiência em mineração como sendo as variáveis "estatisticamente significativas".
} 
Tabela 4.9 - Avaliação de risco de sofrer acidente por queda de rocha em função das variáveis estatisticamente significativas

\begin{tabular}{|c|l|l|c|c|c|}
\hline Perfil & $\begin{array}{l}\text { Características } \\
\text { do trabalhador }\end{array}$ & Equação específica & $\mathrm{P}(\mathrm{Y}=1)$ & $\mathrm{P}(\mathrm{Y}=0)$ & Odds \\
\hline 1 & $\begin{array}{l}\text { Ajudante e } \\
\text { inexperiente }\end{array}$ & $P(Y=1)=\frac{1}{1+\exp (-1,119+2,477-1,690)}$ & 0,58 & 0,42 & 1,39 \\
\hline 2 & $\begin{array}{l}\text { Não ajudante e } \\
\text { experiente }\end{array}$ & $P(Y=1)=\frac{1}{1+\exp (-1,119-1,690)}$ & 0,94 & 0,06 & 16,59 \\
\hline 3 & $\begin{array}{l}\text { Ajudante e } \\
\text { experiente }\end{array}$ & $P(Y=1)=\frac{1}{1+\exp (-1,119+2,477)}$ & 0,20 & 0,80 & 0,26 \\
\hline 4 & $\begin{array}{l}\text { Não ajudante e } \\
\text { inexperiente }\end{array}$ & $P(Y=1)=\frac{1}{1+\exp (-1,119)}$ & 0,75 & 0,25 & 3,06 \\
\hline
\end{tabular}

Para efeitos de interpretação do modelo, e assumindo que as outras variáveis sejam controladas ("Estado civil”, "Escolaridade", "Vínculo empregatício”, "Tempo de serviço" e "Idade") é possível criar quatro perfis. O primeiro deles corresponde a um trabalhador com ocupação de ajudante e experiência menor a três anos. Este trabalhador tem uma probabilidade de sofrer acidente por queda de rochas de 0,58 , ou ainda de ter outro tipo de acidente que não seja por queda de rochas de 0,42. 0 equivalente é válido, isto é, um trabalhador com este perfil teria $39 \%$ de chance a mais de sofrer acidente por queda de rocha do que por outro tipo de acidente.

Observa-se que para o segundo perfil, ou seja, para um trabalhador que não seja ajudante, porém que tenha experiência maior a três anos, a probabilidade de sofrer acidente por queda de rochas é de 0,94. Para o terceiro perfil (trabalhador com função de ajudante e com experiência de mais de três anos) a probabilidade de sofrer acidente por queda de rochas é de 0,20; enquanto que para o quarto perfil (trabalhador com ocupação ou função diferente de ajudante e não experiente) a probabilidade de sofrer acidente por queda de rochas é de 0,75.

A explicação para que a função de ajudante diminua o risco, pode ser explicado porque um trabalhador com estas características pode mostrar um estado de alerta maior durante a execução de uma determinada tarefa, super-dimensiona o risco subjetivamente, mostra maior cuidado no processo de identificação de perigos e a avaliação de riscos, evita o excesso de confiança, oferece maior rigor no cumprimento dos procedimentos operacionais, entre outros.

Por outra parte, o incremento do risco para um trabalhador com experiência 
menor de três anos pode ser explicado pelo excesso de confiança, o relaxamento no cumprimento de procedimentos operacionais, a maior tendência a "by-passar" algumas barreiras, o cumprimento menos estrito dos procedimentos escritos de trabalho seguro, a pressão para o cumprimento de metas de produção, entre outros.

A partir da comparação dos diferentes perfis, é possível determinar as odds ratio (razões de chance), ou seja, quanto mais provável é que um trabalhador com um determinado perfil seja vítima de acidente por queda de rochas quando comparado com um trabalhador com perfil diferente. A Tabela 4.10 mostra as odds ratio para trabalhadores com perfis diferentes, por exemplo, o número na terceira coluna e na segunda fila expressa a odds ratio (razão de chance), entre os dois perfis, o que quer dizer que um trabalhador não ajudante e com experiência de mais de três anos tem 11,91 vezes mais chance de sofrer acidente por queda de rochas do que um trabalhador ajudante e inexperiente. Ou seja, o fato de um trabalhador desempenhar uma função que não seja a de ajudante incrementa a probabilidade de sofrer acidente por queda de rochas quando comparado com um trabalhador que seja ajudante desde que os dois tenham uma experiência maior a três anos.

Tabela 4.10 - Odds ratio ou razões de chance entre os diferentes perfis

\begin{tabular}{lcccc}
\hline \multicolumn{1}{c}{ Perfil } & $\begin{array}{c}\text { Ajudante } \mathrm{e} \\
\text { inexperiente }\end{array}$ & $\begin{array}{c}\text { Não ajudante } \\
\text { experiente }\end{array}$ & $\begin{array}{c}\text { Ajudante e } \\
\text { experiente }\end{array}$ & $\begin{array}{c}\text { No ajudante e } \\
\text { inexperiente }\end{array}$ \\
\hline $\begin{array}{l}\text { Ajudante } \mathrm{e} \\
\text { inexperiente }\end{array}$ & 1,00 & 11,91 & 0,18 & 2,20 \\
$\begin{array}{l}\text { Não ajudante } \\
\text { e experiente }\end{array}$ & 0,08 & 1,00 & 0,02 & 0,18 \\
$\begin{array}{l}\text { Ajudante } \mathrm{e} \\
\begin{array}{l}\text { experiente } \\
\text { Não ajudante }\end{array}\end{array}$ & 5,42 & 64,52 & 1,00 & 11,91 \\
e inexperiente & 0,46 & 5,42 & 0,08 & 1,00 \\
\hline
\end{tabular}

De forma análoga, um trabalhador que desempenha a função de ajudante e que tenha experiência menor que três anos tem 5,42 vezes mais chance de sofrer um acidente por queda de rochas do que um trabalhador que seja ajudante e que tenha experiência maior a três anos.

Um trabalhador não ajudante e com experiência em mineração inferior a três anos tem 2,20 vezes mais chance de sofrer acidente por queda de rochas do que um ajudante inexperiente. Analogamente, um trabalhador que não seja ajudante e com 
experiência maior a três anos tem 64,52 vezes mais chance de sofrer acidente por queda de rochas do que um trabalhador que seja ajudante e com experiência maior a três anos.

\subsection{ANÁLISE DE FATORES CAUSAIS NOS ACIDENTES POR QUEDA DE ROCHAS}

Os relatórios de acidentes elaborados pelos fiscalizadores do Ministério de Energia e Minas do Peru contemplam a identificação de duas categorias de causas de acidentes: uma primeira denominada como causas básicas ${ }^{18}$ e a segunda como causas imediatas $^{19}$. A adoção da divisão em categorias de causas básicas e imediatas sugere uma explicação da causalidade de acidentes centrada na pessoa, ou seja, relacionada à explicação comportamentalista de acidentes de trabalho, o que mostra que no Peru o paradigma de abordagem tradicional ainda não foi quebrado.

A análise das causas fundamentais que se referem aos fatores pessoais mostrados na Tabela 4.11 identifica basicamente seis tipos de erros.

Tabela 4.11 - Fatores pessoais identificados na ocorrência de acidentes por queda de rochas

\begin{tabular}{lcc}
\hline \multicolumn{1}{c}{ Fatores pessoais } & Frequência & Incidência em acidentes (\%) \\
\hline Excesso de confiança & 10 & $66,67 \%$ \\
Falta de experiência & 7 & $46,67 \%$ \\
Motivação deficiente & 6 & $40,00 \%$ \\
Desconhecimento de procedimentos operacionais & 5 & $33,33 \%$ \\
Deficiência na identificação de riscos e perigos & 3 & $20,00 \%$ \\
Pressa na execução de tarefas & 3 & $20,00 \%$
\end{tabular}

O excesso de confiança foi identificado como um dos fatores mais representativos na ocorrência de acidentes por queda de rochas, estando presente em 10 (dez)

18 As causas básicas ou fundamentais compreendem os fatores pessoais e às condições de trabalho. Os fatores pessoais referem-se às qualidades inatas do trabalhador, referentes à insuficiência de capacidade física ou psicológica. Os fatores de trabalho ligam-se a questões da organização e gestão dos sistemas produtivos bem como aos treinamentos; uso de equipamentos e ferramentas; elaboração de normas e procedimentos; supervisão de processos; entre outros.

19 As causas imediatas representam as condições que podem estar abaixo de padrões ou procedimentos e referem-se aos atos e às condições inseguras da abordagem tradicional. Os atos inseguros podem ser classificados em duas categorias: erros e violações cometidos pelos trabalhadores intervenientes diretamente no processo produtivo; enquanto que as condições inseguras se referem às condições latentes caracterizados pelos erros de decisão de gestores. 
acidentes ou em $66,67 \%$ dos eventos. O excesso de confiança, geralmente, é característica de trabalhadores que durante um longo período não experimentaram uma situação de risco iminente, o que ainda leva a pensar em duas possibilidades: uma que sugere que o trabalhador já tem bastante experiência porém nunca encarou um risco iminente ou uma outra situação em que o trabalhador ainda não é ciente dos riscos que envolvem seu ambiente de trabalho o que caracteriza principalmente a trabalhadores novos ou inexperientes.

A falta de experiência foi identificada como sendo o segundo fator pessoal presente na ocorrência de acidentes por queda de rochas, estando presente em sete acidentes ou em $46,67 \%$ dos eventos. Trabalhadores inexperientes não têm os elementos de juízo necessários para antecipar cenários, isto porque os conhecimentos ainda são insuficientes para abstrair determinadas situações e suas consequências, o que faz com que estes não avaliem as consequências de determinados comportamentos considerados como errados.

Os relatorios de acidentes por queda de rochas mostram à motivação deficiente como sendo o terceiro fator pessoal mais importante na ocorrência de acidentes por queda de rochas, estando presente em seis acidentes ou em $40 \%$ dos casos estudados. Trabalhadores desmotivados geralmente não avaliam de forma correta as consequências de seus atos, ou mesmo não desenvolvem interesse em aprender a desenvolver as tarefas assinadas da forma correta, o que incrementa as possibilidades de cometer erros que por sua vez possam causar acidente.

O desconhecimento de procedimentos operacionais de trabalho foi identificado em cinco acidentes ou em 33,33\% dos eventos. O desconhecimento de procedimentos pode ser reforçado pela falta de motivação dos trabalhadores diretamente envolvidos nos processos produtivos ou mesmo pela falta de liderança dos gestores. Em atividades rotineiras como a mineração, o desconhecimento de procedimentos operacionais pode se dar ainda devido à falta de interesse dos gestores em transmitir de forma clara e objetiva os detalhes da atividade.

A deficiência de identificação de perigos e a consequente avaliação de risco, bem como a pressa na execução de tarefas foi identificadas em 3 acidentes cada, os mesmos que estiveram em $20 \%$ dos eventos respectivamente. O desenvolvimento de 
atividades por trabalhadores pouco experientes, confiantes, desmotivados e com insuficiência de conhecimentos necessários executando tarefas de forma apressada, normalmente tem como desfecho a ocorrência de acidentes com consequências graves.

Da análise dos fatores de trabalho que se refere à forma como um sistema produtivo em particular é gerenciado, foram identificados 8 (oito) tipos de fatores na ocorrência de acidentes por queda de rochas conforme mostrado na Tabela 4.12.

Tabela 4.12 - Fatores de trabalho identificados na ocorrência de acidentes por queda de rochas

\begin{tabular}{lcc}
\hline \multicolumn{1}{c}{ Fatores de trabalho } & Frequência & $\begin{array}{c}\text { Incidência em acidentes } \\
(\%)\end{array}$ \\
\hline Supervisão deficiente & 13 & $86.67 \%$ \\
Liderança deficiente & 9 & $60.00 \%$ \\
Comunicação deficiente & 5 & $33.33 \%$ \\
Planejamento inadequado & 4 & $26.67 \%$ \\
Sobrecarga de trabalho & 3 & $20.00 \%$ \\
Treinamento e capacitação deficiente & 3 & $20.00 \%$ \\
Falta de procedimentos específicos & 2 & $13.33 \%$ \\
Engenharia inadequada & 1 & $6.67 \%$
\end{tabular}

A deficiência na supervisão é o principal fator causal de acidentes por queda de rochas, estando presente em treze acidentes, o que corresponde a $86,67 \%$ dos casos. A supervisão nas frentes de lavra subterrânea é feita tanto pelo engenheiro residente pertencente à empresa mineira ou à empresa terceirizada, assim como pelo mestre. Geralmente, a supervisão compreende uma rápida visita na frente de lavra durante a designação de tarefas ou troca de turno, o que dificilmente permite que algumas falhas ou desvios sejam adequadamente identificadas nos locais de trabalho.

A supervisão inadequada pode ser exemplificada por atitudes como falha no direcionamento, doutrina, vigilância, treinamento e falha em buscar qualificação e desempenho de sua equipe. O papel do supervisor é proporcionar condições para o sucesso, independentemente do nível da operação, portanto deve proporcionar direcionamento da sua equipe, treinamento, oportunidades, liderança e motivação. Em muitas organizações os trabalhadores como pessoas, são relegados a um segundo plano, quando se trata de treinamentos e reciclagens.

A deficiência na supervisão pode ser reforçada pela falta de comprometimento dos 
supervisores ou mesmo pela falta de experiência das pessoas encarregadas dessa função. A sobrecarga de trabalho (devido à necessidade das várias frentes serem supervisionadas pelo mesmo profissional) impossibilita que os itens a serem verificados durante as visitas não sejam feitas de forma adequada.

A liderança inadequada por parte dos chefes de turno foi identificada como o segundo fator de trabalho mais importante na ocorrência de acidentes por queda de rochas, estando presente em 9 (nove) casos, o que equivale a dizer que foram identificados em $60 \%$ dos eventos. A liderança é deficiente principalmente quando os encarregados responsáveis por encabeçar os grupos de trabalho estão desmotivados e pouco comprometidos com os objetivos da organização. "Empowerment" é a palavra chave quando se refere à preparação dos subordinados para tomar decisões e agir de forma independente. Isso deve ser feito com o direcionamento dos líderes.

A comunicação deficiente foi identificada como o terceiro fator de trabalho contribuinte para a ocorrência de acidentes por queda de rochas, estando presente em 5 (cinco) eventos, o que equivale a $33,33 \%$ dos acidentes. A comunicação refere-se tanto ao caráter formal quanto ao informal da forma como determinados fatos observados devem ser transmitidos tanto aos supervisores como aos colegas de trabalho.

Relatórios incompletos e inoportunos são fatores que contribuem decisivamente à ocorrência de acidentes. Não são poucos os casos em que as equipes de turnos consecutivos não comunicam algumas falhas ou deficiências identificadas nos locais de trabalho. Assim, as empresas devem estimular a rapidez e precisão da comunicação tanto entre trabalhadores do mesmo nível hierárquico assim como entre os diversos níveis da estrutura organizacional, para que possam ser tomadas as decisões de forma oportuna.

O planejamento inadequado foi identificado como sendo o quarto fator de trabalho mais importante na ocorrência dos acidentes por queda de rochas, estando presente em 4 (quatro) eventos, o que equivale a $26,67 \%$ dos acidentes aqui estudados. $O$ planejamento adequado das tarefas está diretamente relacionado com a disponibilidade de recursos, sejam estes humanos ou financeiros.

Uma característica observada é que empresas pequenas geralmente têm pouca 
disponibilidade de recursos. Além disso, a localização geográfica de algumas minas faz com que nem sempre os recursos necessários estejam disponíveis quando solicitados, levando muitas vezes a executar tarefas em condições abaixo de determinados padrões operacionais recomendados, sob justificativa do cumprimento dos planos de produção estabelecido pela empresa mineira.

A deficiência no planejamento de operações se dá em situações em que o ritmo operacional e a programação colocam as pessoas em uma situação de risco inaceitável. Essas situações ocorrem e são toleradas conduzindo à sobrecarga de trabalho, fator identificado em três acidentes, o que corresponde a $20 \%$ dos eventos. Planos de produção ambiciosos ou falhas em turnos anteriores fazem com que as equipes sejam orientadas e estimuladas a aumentar o ritmo de produção. Ainda em minas pequenas com pouca disponibilidade e confiabilidade de equipamentos fazem que os programas de produção não sejam cumpridos, o que significa que alguns cuidados no que se referem à segurança não sejam adotados.

Não é raro ainda ouvir o discurso dos chefes de empresas terceirizadas, indicando a importância de garantir o programa de produção estabelecido pela empresa, o que faz com que alguns itens dos procedimentos escritos de trabalho seguro sejam omitidos. Este detalhe relaciona-se fortemente à cultura organizacional tanto da empresa mineira hóspede assim como das empreiteiras. No entanto, não é pouco frequente o convívio consentido de comportamentos considerados como errados até quando acontecer um evento indesejado.

O treinamento e a capacitação insuficientes estiveram presentes em 3 (três) acidentes por queda de rochas, o que corresponde a $20 \%$ dos casos estudados. O treinamento pode ser considerado deficiente ou insuficiente quando não tem o mínimo de horas necessárias para garantir a incorporação de conhecimentos e comportamentos considerados necessários para o desenvolvimento das tarefas assinadas de forma segura e produtiva; ou quando a qualidade do mesmo pode ser insatisfatória.

A maioria das empresas mineiras no Peru considera de extrema importância a educação dos seus trabalhadores; no entanto, ainda o caráter formal desse processo é insuficiente. Estas empresas mineiras, de forma geral, consideram como suficiente a 
experiência prévia do trabalhador em atividades de mineração no momento da contratação, assumindo que o mesmo reúne todas as condições necessárias para que possa desenvolver-se de forma satisfatória no novo posto de trabalho. Neste processo de recolocação do trabalhador, algumas vezes são omitidos alguns aspectos formais da capacitação o que pode ter como consequência acidentes de trabalho, devido às novas características ambientais e situacionais que o trabalhador deve enfrentar.

Finalmente, a engenharia inadequada foi identificada na ocorrência de um acidente por queda de rochas. A engenharia inadequada basicamente está referida à elaboração e implantação incorreta de projetos, seja pela deficiência de critérios, deficiência no dimensionamento de equipamentos, dispositivos ou elementos de suporte mal dimensionados, entre outros.

Da análise das causas imediatas referidas aos atos inseguros foram identificados basicamente 4 (quatro) tipos de erros conforme se mostra na Tabela 4.13. A rotulação de erros como "atos inseguros", segundo vários autores, apresenta implicitamente a ideia tendenciosa de responsabilizar a vítima pelo acidente. Apesar do uso abusivo dessa tendência por parte dos investigadores de acidentes, é importante tentar ir além do óbvio, procurando identificar as verdadeiras causas de acidentes.

Tabela 4.13 - Atos inseguros identificados na ocorrência de acidentes por queda de rochas

\begin{tabular}{lrc}
\hline \multicolumn{1}{c}{ Atos inseguros } & Frequência & Incidência em acidentes (\%) \\
\hline Descumprimento de procedimentos operacionais & 11 & $73,33 \%$ \\
Não identificar o perigo & 8 & $53,33 \%$ \\
Retirada deficiente de rochas soltas no teto & 6 & $40,00 \%$ \\
Deficiência no uso de equipamentos de proteção individual & 1 & $6,67 \%$
\end{tabular}

O descumprimento de procedimentos operacionais foi identificado em 11 (onze) acidentes, o que corresponde a $73,33 \%$ dos eventos estudados. O descumprimento de procedimentos pode se dar devido à falta de compreensão do mesmo, a uma ação deliberada por parte do trabalhador, o que quer dizer que existe uma violação de uma regra e, no caso extremo, quando existe uma ação mal intencionada para quebrar as barreiras e defesas dos sistemas de defensa da organização (sabotagem).

A deficiência na identificação de perigos e a correspondente avaliação dos riscos constituem o segundo tipo de erro mais representativo na ocorrência de atos inseguros, 
sendo identificado em 8 (oito) acidentes, o que corresponde a 53,33\% dos casos. Este tipo de erro é caracterizado por deslizes e lapsos, ou seja casos em que o trabalhador comete erros por automatismos em atividades rotineiras, devido à falta de atenção ou monitoramento durante a execução de uma ação em particular, ou mesmo pela omissão de alguns detalhes considerados nos procedimentos de trabalho seguro. $A$ deficiência na identificação de perigos e avaliação de riscos também é uma característica das organizações onde os gestores e trabalhadores estão despreparados, desmotivados e pouco comprometidos com a segurança.

A deficiência na retirada de rochas soltas é apontada como sendo o ato inseguro que foi identificado em 6 (seis) acidentes, o que corresponde a $40 \%$ dos casos estudados. A deficiência na retirada de rochas soltas do teto (chocos) deixa implícito que, apesar de identificada a presença de rocha solta pelo do teste de percussão, a rocha com possibilidade de queda não foi retirada, seja porque o trabalhador considerou desnecessário (o julgamento subjetivo considera que o risco é baixo) ou pela pressa na execução da tarefa devido à sobrecarga de trabalho.

A avaliação do estado do teto por parte do trabalhador é bastante subjetivo, e depende da experiência e da habilidade deste. Geralmente, esta tarefa é designada ao ajudante de perfuração, que na maioria dos casos é pouco experiente, assim, este tem poucos recursos cognitivos para fazer uma "avaliação confiável" que aliado à deficiência na supervisão e ao pouco comprometimento das pessoas envolvidas pode resultar em acidente.

Outro aspecto que é relevante na deficiência na retirada de blocos soltos no teto diz respeito aos meios utilizados para tal. A maioria das minas, mesmo sendo as mecanizadas, utiliza em vários frentes de trabalho, principalmente nas vias de desenvolvimento, técnicas ainda manuais, ou seja, a retirada é feita usando barras ou hastes. No contexto da mineração moderna, no qual onde a aplicação de técnicas mecanizadas como a utilização de "scalers", o uso de meios manuais pode já ser considerada como uma "deficiência" desde sua concepção e sua permissão,o que de fato é uma responsabilidade da gerência. No entanto, a mecanização de retirada de rochas dificulta a percepção de trincas e avisos sonoros (FARIA, 2008).

Finalmente, o uso inadequado de equipamentos de proteção individual é apontado 
como sendo responsável pela ocorrência de um acidente fatal por queda de rochas. É importante ressaltar que o uso de EPI não evita a ocorrência do acidente, porém minimiza suas consequências. No entanto, embora sua concepção tenha como objetivo a minimização das consequências dos acidentes, seu uso diminui também a sensibilidade sensório-motora do trabalhador, o que, segundo a maioria dos trabalhadores, é um motivo para a omissão ou uso inapropriado de EPI's.

$\mathrm{Na}$ análise das condições inseguras identificadas na ocorrência de acidentes por queda de rochas foram notadas basicamente 8 (oito) categorias conforme é mostrado na Tabela 4.14. As condições inseguras de trabalho são aquelas que estão abaixo de determinados padrões, revelando inadequação para o desenvolvimento de atividades de forma segura.

Tabela 4.14 - Condições inseguras identificadas na ocorrência de acidentes por queda de rochas

\begin{tabular}{lcc}
\hline \multicolumn{1}{c}{ Condições inseguras } & Frequência & Incidência em acidentes (\%) \\
\hline Presença de rochas soltas no teto & 12 & $80,00 \%$ \\
Deficiência na instalação de elementos de & & \\
suporte & 3 & $20,00 \%$ \\
Caracterização geológica deficiente & 2 & $13,33 \%$ \\
Deterioração de componentes de instalações & 2 & $13,33 \%$ \\
Presença de infiltrações & 2 & $13,33 \%$ \\
Deficiência no sistema de iluminação & 1 & $6,67 \%$ \\
Manutenção preventiva deficiente & 1 & $6,67 \%$
\end{tabular}

Embora a presença de rochas soltas (chocos) seja uma condição necessária para a ocorrência deste tipo de acidentes, esta ocorreu em 12 (doze) acidentes, o que representa $80 \%$ dos eventos. Da análise dos relatórios pode-se inferir que apesar de que no momento da verificação do teto pela técnica de percussão com haste rígida, esta não advertia presença de rochas, porém, devido à presença de infiltrações; à mudança de mergulho do filão ou mesmo à falha do elemento de suporte aconteceu o desprendimento de rocha aparentemente firme.

A deficiência de elementos de suporte foi identificada como a segunda categoria de condição insegura identificada em acidentes por queda de rochas, estando presente em 3 (três) acidentes, o que representa 20\% dos eventos. A deficiência de elementos de suporte refere-se basicamente à instalação de dispositivos como chumbadores, 
quadros de madeira, telas de aço, concreto projetado, entre outros; que não são compatíveis com os esforços solicitantes no local devido a um dimensionamento equivocado ou mesmo devido à deficiência no controle de qualidade dos mesmos.

A deficiência na caracterização geológica foi definida como sendo a terceira condição insegura mais importante na ocorrência de acidentes por queda de rochas estando presente em 2 (dois) acidentes. Esta categoria de condição insegura refere-se à deficiência da caracterização geoestrutural e hidrogeológica do maciço onde são desenvolvidos os painéis de lavra. É importante ressaltar que um maior investimento nas fases exploratórias com a finalidade de reduzir as incertezas (por exemplo, através de uma melhor caracterização geológica), permitirá a redução de eventuais futuros custos resultante de acidentes.

A deterioração de componentes de instalações de elementos de suporte foi identificada em 2 (dois) acidentes. A deterioração de componentes refere-se ao estado deficiente de componentes de elementos de suporte principalmente em vias subterrâneas de caráter permanente como galerias principais, chaminés, poços, rampas de acesso, pontos de transferência de carga, entre outros. Este tipo de condição insegura pode ser gerada pela deficiência na verificação das condições nos locais de trabalho ou mesmo, depois de verificado que a situação é precária, não são tomadas as ações necessárias para corrigir as deficiências identificadas.

A presença de infiltrações foi identificada em 2 (dois) acidentes, decorrente da presença de águas em vias e escavações subterrâneas, que devido às condições hidrogeológicas acabam comprometendo a estabilidade do maciço rochoso. Geralmente, este tipo de inconveniente está associado à deficiência de caracterização geológica, ou mesmo à falha no controle de drenagem de águas superficiais e subterrâneas.

A deficiência de iluminação foi identificada em um acidente. Minas subterrâneas, principalmente as de pequeno porte, são caracterizadas pela deficiência de iluminação tanto em vias subterrâneas como em frentes de lavra. Esta condição dificulta a identificação de perigos e mesmo a adoção de medidas tanto preventivas como corretivas.

Finalmente, a deficiência na manutenção preventiva foi identificada como a 
responsável pela ocorrência de um acidente. A manutenção preventiva refere-se ao reparo antecipado de elementos de suporte considerados como deficientes. Uma supervisão deficiente não identifica os perigos de forma correta, assim a adoção de medidas corretivas é comprometida, tendo como resultado acidentes de trabalho.

É importante salientar que na identificação de erros ou falhas para a gênese de acidentes por meio de estudos de caso a partir de relatórios de acidentes de trabalho é inevitável encontrar inconvenientes, como a limitação da informação contida tanto na exatidão como na abrangência, o que leva, na maioria das vezes, a uma abordagem simplista e enviesada da responsabilização da vítima pelo evento indesejado.

Embora os processos de investigação sejam feitos por profissionais experientes pertencentes ao Ministério de Minas do Peru, os relatórios de acidentes gerados, geralmente contém menos informação do potencialmente disponível. Além disso, o conteúdo escrito normalmente é influenciado por eventos relatados em oportunidades anteriores (insight biases). Outra questão é a superficialidade com a qual é feita uma análise de acidentes; assim, as causas verdadeiras dos acidentes não são descobertas (REASON, 1999; WOODS e COOK, 2002). Estes inconvenientes incentivam, em muitos casos, a adoção de abordagens simplistas.

Uma importante conclusão que pode ser tirada a partir da identificação dos erros humanos por meio de estudos de caso é que os acidentes dificilmente são consequência de uma única causa. Usualmente, estes envolvem a concatenação de alguns erros cometidos por uma ou várias pessoas. Apesar de que o simples conhecimento da ocorrência de eventos passados não previne os futuros, a combinação do conhecimento obtido a partir de estudos de caso, junto com uma adequada teoria da produção de erros, não só amplia nossos conhecimentos; permite também montar um corpo de princípios que, quando aplicados ao projeto e implementação de tecnologias de alto risco, poderia contribuir à redução de ocorrência de erros e suas consequências negativas (REASON, 1999). 


\section{CONSIDERAÇÕES ADICIONAIS NA ANÁLISE DE ACIDENTES POR QUEDA DE ROCHAS NA MINERAÇÃO PERUANA}

No intuito de garantir a segurança dos trabalhadores nas escavações subterrâneas, deverão ser desenvolvidos projetos adequados das entradas, pilares, tetos, dimensões da escavação entre outros, tendo em consideração os princípios da mecânica de rochas, assim como os métodos de monitoramento e controle de escavações subterrâneas.

Para prevenir a queda de rochas nas frentes de lavra deve ser elaborado um procedimento específico de identificação e retirada de blocos soltos. Em seguida, deverão ser colocados os elementos de suporte mais adequados, os quais serão determinados em função das condições existentes no local. Essas atividades devem contemplar a implementação de métodos mecanizados que minimizariam os riscos de acidentes.

Os relatórios de acidentes elaborados pelos técnicos do MEM do Peru são incompletos, oferecendo pouca informação para o desenvolvimento de um estudo mais aprofundado. A compreensão do acidente exige uma descrição muito mais completa e detalhada: das circunstâncias, antecedentes, status e papéis, funções e atividades dos trabalhadores. Desta maneira, a descrição do acidente não se deve reduzir a uma mera descrição esquemática de tipo causa - efeito.

A análise dos sistemas sócio-técnicos mostra que seu funcionamento está repleto de anomalias, disfunções, incidentes, e perturbações (não conformidades) que devem ser corrigidas. O registro e a análise destas não conformidades permitiriam a proposta de medidas preventivas orientadas ao controle de riscos tecnológicos próprios dos sistemas produtivos, evitando que os quase - acidentes se transformem em acidentes.

Os relatórios de acidentes desenvolvidos pelos técnicos do MEM descrevem os acidentes como sendo uma sucessão de fatos essencialmente técnicos. Existe, assim, uma falha no entendimento do principal protagonista, ou seja, o ser humano; o que significa que uma descrição subjetiva do acidente, estabelecida a partir da experiência vivida pelos protagonistas e normalmente ausente nos relatórios deveria ser incorporada. 
A identificação e a antecipação de desvios ou inconformidades em ambientes mineiros necessitam de experiência e conhecimentos específicos, principalmente no que diz respeito às operações unitárias e aos serviços auxiliares envolvidos, às habilidades dos trabalhadores, assim como à natureza mutável do ambiente de trabalho. Fica claro que em todos os eventos analisados no presente estudo houve a contribuição de mais de um fator causal, o que evidencia a hipótese da multicausalidade dos acidentes de trabalho.

$\mathrm{Na}$ abordagem tradicional da análise e do estudo de acidentes, quando se faz referência aos erros humanos, implicitamente, faz-se referência aos operadores do fim da linha de produção (erros ativos). Entretanto, esses relatos não indicam a participação dos gestores (erros latentes) na ocorrência dos acidentes, limitando a causalidade dos acidentes a fatores imediatos aos eventos. Esta abordagem enviesada reforça a tese de que o fator humano constitui o elo fraco, quando o assunto em questão é a ocorrência de acidentes.

Descrições mais detalhadas de acidentes de trabalho por parte dos técnicos responsáveis pela sua investigação fazem falta. Relatórios mais completos com informações mais detalhadas dos acidentes, incluindo-se aí os testemunhos, mesmo que contraditórios, dos principais protagonistas ajudariam significativamente na proposta de medidas de controle de riscos tecnológicos.

Os procedimentos de trabalho escrito compreendem em princípio, diretrizes e regulamentos de como devem ser desenvolvidas as tarefas, ou seja, o trabalho prescrito. Entretanto, a realidade do trabalho juntamente à variabilidade do ambiente de trabalho, coloca em evidência que estas prescrições têm algumas deficiências. Os trabalhadores, diante deste quadro, são obrigados a interpretá-los e preencher essas lacunas.

Os problemas de comunicação em ambientes de trabalho são frequentes. O uso por parte de engenheiros de linguagens técnicas mais sofisticadas muitas vezes não são compreendidas pelos operadores, podendo agravar a inteligibilidade da comunicação oral e escrita. Além disso, a comunicação "buttom up" (de baixo para cima), particularmente quando se coloca em evidência as deficiências do sistema, nem sempre são bem recebidas pelos gestores. 
A impossibilidade de discutir e negociar situações de trabalho, bem como de fazer chegar aos níveis hierárquicos competentes certos aspectos críticos da realidade do trabalho cotidiano, podem provocar, entre outras coisas, o afastamento, a desmobilização e o fatalismo nos ambientes de trabalho. Nesse contexto, existe a necessidade de estimular debates abertos com o intuito de incorporar as opiniões dos operadores nos procedimentos de trabalho de modo seguro e eficiente, baseados na filosofia da melhoria contínua.

O registro e a análise de incidentes e quase acidentes; ou seja, os acidentes e incidentes graves que foram evitados, podem revelar problemas sutis relativos à insuficiência de procedimentos, barreiras e mesmo erros de concepção dos sistemas produtivos; entretanto, esta prática ainda é pouco difundida na mineração do Peru. Um estudo desta natureza, ao identificar certas vulnerabilidades do sistema, permitiria adotar medidas pró-ativas ao invés de reativas.

É importante ainda salientar que as equipes de engenharia de segurança do trabalho devem apresentar esforços para entender o trabalho real dos operadores, ou seja, entender como o elemento humano reage frente à variabilidade do ambiente de trabalho em uma dada circunstância. É aqui que a ergonomia pode contribuir significativamente na melhoria de procedimentos de trabalho seguro.

Apesar da existência formal de procedimentos de trabalho seguro em todas as minas de medio e grande porte; quando o assunto em questão, refere-se à retirada manual de rochas soltas nas frentes de lavra, o trabalho em si é executado em condições de risco crítico iminente, ou seja, em situações em que qualquer descuido do operador pode resultar em acidente grave.

Embora a utilização da mecanização da retirada de rochas soltas pelo uso de "Scalers" seja recomendada para constituir uma forma mais segura de desenvolver esta atividade, sua utilização no Peru ainda é inexistente. Desde o ponto operacional, sua aplicação seria viável na construção de escavações de desenvolvimento ou vias de transporte principal. No entanto, em frentes de produção sua aplicação é inviável pelas mesmas restrições dos métodos de lavra utilizados no Peru. 


\section{CONCLUSÕES}

A indústria da mineração é uma das atividades mais importantes da economia peruana, observada na sua capacidade de geração de empregos diretos e indiretos, tornando-se assim um elemento de desenvolvimento econômico, principalmente em regiões menos desenvolvidas. No entanto, esta atividade se caracteriza também pelo alto risco oferecido no seu exercício, o que se traduz na alta taxa de acidentes quando comparado com outras atividades econômicas.

Para o período compreendido entre 2000 e 2007, a queda de rochas constituiu o tipo de acidente fatal mais representativo, com 36,79\% das ocorrências. Ainda em 2007, este tipo de acidente representou $29,41 \%$ dos acidentes fatais na mineração peruana de médio e grande porte, mostrando seu impacto na prevenção de acidentes.

A aplicação de Métodos de Regressão Logística (MRL) na estimativa da probabilidade de um trabalhador sofrer acidente por queda de rochas, através do modelo gerado, tem mostrado que sob o ponto de vista estatístico as variáveis explicativas mais significativas são a ocupação e a experiência do trabalhador na mineração.

A interpretação do modelo gerado permite inferir que o fato de um trabalhador desenvolver a função de ajudante ou servidor geral constitui um fator de proteção quando comparado com um trabalhador exercendo outra função. Pode-se concluir também que o fato de um trabalhador ter uma experiência inferior a três anos incrementa o risco de sofrer acidente por queda de rochas.

Para o ano 2007 análise estatística descritiva das características pessoais das vítimas mostra ainda que trabalhadores que desempenham a função de manobristas e ajudantes de perfuração foram os que mais sofreram acidentes tendo como causa a queda de rochas em escavações subterrâneas, principalmente por estes estarem expostos a situações de risco maior; ou seja, por desempenharem suas funções em frentes de trabalho com potencial de queda de rochas, próprias de tarefas de identificação e remoção de rochas soltas, perfuração e instalação de elementos de suporte. 
A análise da causalidade de acidentes a partir dos relatórios elaborados pela equipe técnica do Ministério de Energia e Minas do Peru, mostra que na origem de acidentes por queda de rochas normalmente existe mais de um fator causal. Neste contexto, as partes interessadas (governo, empresas e sindicatos) de alguma maneira são responsáveis, principalmente por não estabelecer mecanismos de prevenção e controle mais eficazes.

A abordagem da análise de acidentes de trabalho no cenário peruano ainda mostra uma tendência tradicional em que geralmente se considera a vítima como sendo a maior responsável pela ocorrência de um acidente. O presente estudo permitiu identificar as causas básicas e fundamentais que ocasionaram o acidente, isto, por sua vez, serve para que ações corretivas possam ser tomadas visando à minimização de eventos desta natureza.

Os relatórios de acidentes no Peru mostram ainda uma tendência arbitrária de classificação e tipificação dos acidentes em categorias gerais. Esta simplificação, junto à tendência quase generalizada de responsabilização da vítima, faz com que um acidente perca sua especificidade haja vista a diversidade de comportamento das pessoas, e consequentemente o conhecimento real de suas causas, o que finalmente dificulta a proposição de medidas preventivas mais eficazes.

O estudo dos acidentes de trabalho a partir de relatórios de acidentes fatais mostra sérias limitações, pois inúmeras perguntas ainda permanecem sem respostas, principalmente devido à ausência dos principais protagonistas, ou seja, a própria vítima. Desta maneira, ao não se dispor de esclarecimentos dos eventos prévios ao acidente, cria-se uma dificuldade na compreensão dos vazios ou das deficiências existentes no sistema.

Além da falta de uma descrição mais rigorosa nos relatórios de acidentes de trabalho, o acesso a estes documentos por parte do público interessado no seu estudo é restrita e alem disso, os especialistas e gestores dessas informações têm a tendência de manter as análises e discussões em círculos restritos.

Face à dificuldade da mecanização de retirada de rochas soltas em frentes de lavra de produção, recomenda-se melhorias na gestão de riscos, especialmente no que diz respeito ao uso de barreiras físicas, sinalização e aspectos comportamentais. A 
inspeção prévia mais rigorosa das frentes de lavra por profissionais competentes pode diminuir significativamente a ocorrência de acidentes por queda de rochas.

O modelo matemático gerado no presente estudo mostra algumas limitações, principalmente pelo tamanho amostral utilizado, assim como por ter-se desenvolvido a partir de dados coletados por terceiros (relatórios de acidentes de trabalho elaborados pelos técnicos do MEM do Peru). Para superar este inconveniente, recomenda-se a aplicação desta metodologia numa mina em particular, onde possa ser gerada uma base de dados mais consistente a partir do registro de acidentes (fatais e não fatais).

A metodologia empregada neste trabalho para a avaliação de riscos, pode ser utilizada também para futuras pesquisas de caráter epidemiológico, como por exemplo: a incidência de enfermidades ocupacionais como as doenças pulmonares, cardíacas, tecnopatias, entre outros, o que permitiria a proposição de medidas preventivas mais eficazes na indústria da mineração. 


\section{REFERÊNCIAS BIBLIOGRÁFICAS}

AGRESTI, A. An introduction to categorical data analysis. New York: John Wiley \& sons, Inc., 1996. 290 p.

ALFARO, L. A. Optimización de los sistemas de gestión en prevención de pérdidas humanas en la industria minera. Sétimo congreso Nacional de minería. Trujillo - Perú, 2008.

ALMEIDA, M. I. Trajetória da análise de acidentes: o paradigma tradicional e os primordios da ampliação da análise. Interface - Comunic, Saúde, Educ, v.9, No.18, p. 185 - 202, 2006a.

ALMEIDA, M.I. Abordagem sistêmica de acidentes e sistemas de gestao de saúde e segurança do trabalho 2006b. 27 p. Disponível em:

http://www.interfacehs.sp.senac.br/artigod.asp?ed=2\&cod artigo=32. Acesso em: 20/03/2010.

ASSOCIAÇÃO BRASILEIRA DE NORMAS TÉCNICAS. NBR ISO 9001: Sistemas da Gestão de Qualidade - Requisitos. Rio de janeiro, 2000a. 21 p.

ASSOCIAÇÃO BRASILEIRA DE NORMAS TÉCNICAS. NBR ISO 9004: Sistemas de Gestão da qualidade - Diretrizes para melhorias de desempenho. Rio de Janeiro, 2000b. 48 p.

ASSOCIAÇÃO BRASILEIRA DE NORMAS TÉCNICAS. NBR 14280: Cadastro de acidente do trabalho - Procedimento e classificação. Rio de Janeiro, 2001. 94 p.

ASUNÇÃO, A. A.; LIMA, F. A. A contribuição da ergonomia para a identificação, redução e eliminação da nocividade do trabalho. A patologia do trabalho. 2001, p. 17681787.

BAJPAYEE, T.S. et al. Blasting injuries in surface mining with emphasis on flyrock and blast area security. Journal of Safety Research. No. 35, 2004, p. 47-57.

BARREIROS, D. Gestão da segurança e saúde no trabalho: estudo de um modelo sistêmico para as organizações do setor mineral. 2002. 317 p. Tese (Doutorado) Escola Politécnica da Universidade de São Paulo, São Paulo, 2002.

BATTACHERJEE, A. Mine safety management: An application of risk analyses, forecasting techniques, and Markov process to injury experience data. 1991. 301 p. Doctoral Thesis - The Pennsilvania State University, 1991.

BIENIAWSKI, Z.T. Engineering rock mass classification: a complete manual for engineers and geologist in mining, civil and petroleum engineering. New York: John Wiley \& sons, Inc., 1989. 251 p.

CANDIA, R.C. Acidentes de trabalho na lavra de minas. 2010a. 67 p. Monografia (Especialização em Engenharia de Segurança do Trabalho) - Escola Politécnica da Universidade de São Paulo. Programa de Educação Continuada em Engenharia, São Paulo, 2010. 
CANDIA, R.C. et al. Análisis de accidentes fatales en la industria minera peruana. Boletín Geológico y Minero de España. No. 1. 2010b, p. 57-68.

CORREA, C.R. e JUNIOR, M.M. Análise e classificação dos fatores humanos nos acidentes industriais. Produção, No. 1, 2007. p 186-198.

DOLINAR,D.R.; MARK,C.; MOLINDA, G.M. Design of Primary Roof Support Systems in US Coal Mines Based on the Analysis of Roof Fall Rates, NIOSH Pittsburg Laboratory, USA (2001).

DUNCAN, N; DEVANE, M.A. Geological and geotechnical criteria for assessing the stability of inclines, headings and tunnels in rock. In: BRAWNER, C.O (Edit) Stability in underground mining. 1983, p. 136-165.

DUZGUN, H.S.; EINSTEIN,H.H. Assessment and management of roof fall risks in underground coal mines. Safety Science, No. 42, 2004, p. 23-41.

FARIA, P. M. Fatores intervenientes na segurança do trabalho de abatimento mecanizado de rochas instáveis em uma mina subterrânea de ouro. 2008. 66 P. Dissertação (mestrado) - Universidade Federal de Minas Gerais, Faculdade de Medicina, Belo Horizonte, 2008.

FRICK, K. Systematic occupational health and safety management: an introduction to a new strategy for occupational safety, health and well-being. Systematic occupational heath and safety management: perspectives on an international development. Amsterdam, 2000, p. 1-42.

GRANADO, J. C. Modelos de regresión logística incondicional. Cádiz, Sociedad Andaluza de enfermedades infecciosas. Disponível em:

http://saei.org/hemero/epidemiol/nota6.html. Acesso em: 22/07/2009.

GHOSH, A. K.; BHATTACHERJEE, A. e CHAU, N. Relationships of working conditions and individual characteristics to occupational Injuries: a case-control study in coal miners. Journal of Occupational Health, v.46, n.6, 2004, p.470-478.

GROVES, W.A. V.J.; KECOJEVIC,V.J.; KOMLJENOVIC, D. Analyses of fatalities and injuries involving mining equipment. Journal of Safety Research. No. 38, 2007, p. 461470.

GYEKYE, S. A. Causal attributions of Ghanaian industrial workers for accident occurrence: Miners and non-miners perspective. Journal of Safety Research, v.34, n.5, 2003, p. 533-538.

HAMALAINEN, P. The effect of globalization on occupational accidents. Safety Science, No. 47, 2009, p. 733-742.

HENNIES, W.T.; AYRES DA SILVA, L. Abertura de vias subterrâneas. São Paulo: Epusp, 2006. 338 p. Apostila para a disciplina de graduação do Departamento de Engenharia de Minas e petróleo PMI - 2943 - Abertura de vias subterrâneas. 
HIDALGO, N.C.; GOMEZ, E.G. Propuesta de estructura organizacional para la prevención de accidentes en el sector minero. Revista del Instituto de Investigación FIGMMG de la Universidad Nacional Mayor de San marcos. V. 8, No. 15, 2005, p. 3334.

HOEK, E. Rock engineering: the application of modern techniques to underground design. Sâo Paulo, 1998. 268 p.

HOEK, E.; KAISER, P.K.; BAWDEM, W.F. Support of underground excavations in hard rock. Rotterdam, 2000. 215 p.

HUNTING, K.L.; WEEKS, J.L. Transport injuries in small coal mines: An exploratory analyses. American Journal of Industrial Medicine, No. 23, 1993, p 391-406.

HOSMER, D. W.; LEMESHOW, S. Applied logistic regression. New York: John Wiley \& Sons, 1989. 307 p.

INTERNATIONAL LABOUR ORGANIZATION. Cases of injury with lost workdays, by economic activity. Disponivel em: http://laborsta.ilo.org/STP/guest. Acesso em: 23/03/2010.

IRAMINA, W. S. Contribuições sobre a vibração do terreno e a sobrepressão atmosférica na elaboração do EIA de uma mina de nefelino-sienito. 2007. 276 p. Tese (Livre docencia) - Escola Politécnica da Universidade de São Paulo, São Paulo, 2007.

KECOJEVIC, V.; RADOMSKI, M. Flyrock phenomena and area security in blastingrelated accidents. Safety Science, No. 43, 2005, p. 739-750.

LAPA, R. G. Gerência de riscos: investigação e análise de incidentes do trabalho. (Apostila de aulas Pece). São Paulo, 2009. 63 p.

LEGER, J. Trends and causes of fatalities in South African mines. Safety Science, v. 14, No. 3, 1991, p. $169-185$.

LEVESON, N. Safety in integrated systems health engineering and management. $21 \mathrm{p}$. 2005. Disponível em sunnyday.mit.edu. Acesso 20/05/2010.

LLORY, M. Acidentes industriais: o custo do Silencio. Rio de Janeiro: MultiMais editorial, 1999. $316 \mathrm{p}$.

MASSAD, E. Métodos quantitativos em medicina. Barueri, SP: Manole, 2004. 561 p.

MAXIMIANO, A. C. Teoria geral da administração: da revolução urbana a revolução digital. São Paulo: Atlas, 2008. 491 p.

MINE SAFETY AND HEALTH ADMINISTRATION (MSHA). Injury experience in coal mining. Department of labor, Mine Safety and Health Administration. Office of Injury and employment information. IR 1253. Denver, CO, 1997, p. 5-7. 
MINE SAFETY AND HEALTH ADMINISTRATION (MSHA). Metal/Nonmetal Fatal Accident Review. Disponivel em http://www.msha.gov/stats/review/2010/2010review.asp. Acesso 13/04/2011.

MAITI, J.; VIVEK, V.; KHANZODE. Development of a relative risk model for roof and side fall fatal accidents in underground coal mines in Índia. Safety Science, No. 47, 2009, p. 1068-1076.

The National Institute for Occupational Safety and Health (NIOSH). Lesiones por derrumbes de rocas en minas subterrâneas. Disponivel em: www.cdc.gov/spanish/niosh/docs/2004-106sp.html. Acesso em: 01/12/2008.

OCCUPATIONAL HEALTH AND SAFETY ASSESMENT SERIES (OHSAS) 18001. Sistema de Gestão de Segurança e Saúde Ocupacional - Especificação. 1999. 17 p.

ORTIZ, S.O.; FERNANDEZ, C. F.; BLAS, G. W. Sostenimiento activo de excavaciones mineras subterráneas y a cielo abierto mediante el mortero de resina en pernos y tendones de anclaje. Revista del instituto de investigación FIGMMG de la universidad nacional mayor de San Marcos. V.6, No.11, 2003, p. 42-50.

OTTERMANN, R. W. et al. Investigate a possible system for 'making safe'. Final Project Report, GEN 801, SIMRAC, South Africa, Feb. 2002. Disponível em: < http://www.mhsc.org.za/dmdocuments/Reports/GEN/gen801/Gen801 report final.pdf>. Acesso em: 24/06/2009.

PALEI, S. K.; DAS, S.K. Logistic regression model for prediction of roof fall risks in bord and pillar workings in coal mines: An approach. Safety Science. No. 47 2008, p. 88-96.

PAUL, P.S.; MAITI, J. The role of behavioral factors on safety management in underground mines. Safety Science, No. 45. p. 449-471, 2007.

PAULA, G. A. Modelos de regressão com apoio computacional. São Paulo: Instituto de matemática e estatística da USP, 2004. 245 p.

PEAKE, A. V.; ASHWORTH, S. G. E. Factors influencing the detections of unsafe hangingwall conditions. Final Project Report, GAP 202, SIMRAC, South África, Oct. 1996. Disponível no site:

<http://researchspace.csir.co.za/dspace/bitstream/10204/1691/1/GAP202.pdf >. Acesso em: 19/05/2009.

PERU. Decreto Supremo No.046-2001a - EM. Reglamento de seguridad e higiene minera. ISEM, Lima - Peru. 2001a, 223 p.

PERU. Ministério de energia y minas del Peru. Atlas minero 2008. Lima, 2008a. 85 p.

PERU. Modificación de los artículos $2^{\circ}, 11^{\circ}, 14^{\circ}$ de la ley No. 27651. Ley de formalización y promoción de la pequena minería y mineria artesanal. El Peruano, $2008 b$, p $374784-374785$.

PERU. Ministério de Energia y Minas del Peru. 2010 database. Lima, 2010. 1 CD-ROM. 
PHILLIPSON, S.E. Control of coal bed decollement-related slickensides on roof falls in North American late paleozoic coal basins. International journal of coal geology, No. 53, 2003, p. 181-195.

REASON, J. Human error. $2^{\text {nd }}$ Ed. Cambrige: Cambrige University press; 1999. 301 p.

RIKHARDSSON, P.M. e IMPGAARD, M. Corporate cost of occupational accidents: an activity-based analysis. Accidents Analyses and Prevention, No. 36, p. 173-182, 2004.

REHAK,T.R. et al. Flyrock issues in blasting. Proceedings of the 27th annual conference on explosives and blasting techniques, 2001. v. I. International society of explosive engineers, Cleveland, 2001. p. 339-348.

SAMAME, B.M. El Perú Minero: Historia. Lima, 1979. 347 p.

SILVA. L. C. Excursión a la regresión logística en ciencias de la salud. Madrid: Ediciones Días de Santos, 1995. 232 p.

STATISTICAL PRODUCT AND SERVICE SOLUTIONS. Statistical Package for the Social Science" SPSS® 15.0. USA. 2006. (pacote estatístico para as ciências sociais).

QUISPE, R.I. Análisis del origen de caída de rocas y su prevención en la minería subterránea. Sétimo congreso Nacional de minería. Trujillo - Perú, 2008.

TARALLI, G. Gerência de riscos. Apostila de aulas Pece. São Paulo, 2009. 261 p.

TROTTER, D. A., KOPESCHNY, F. V. Cap lamp improvement in canadian mines. Applied occupational environmental hygiene, v.12, No.12, 1997, p. 859-863.

TORLONI, M.; VIEIRA, A. V. Manual de proteção respiratória. São Paulo, 2003. 520 p. UDD, J. E. Instability Underground - Causes, cost and controls. In: BRAWNER, C.O (Edit) Stability in underground mining, 1983, p. 123-136.

VERAKIS, H. C.; LOBB, V. Blasting accidents in surface mines, a two decade summary. Proceedings of the 27th annual conference on explosives and blasting techniques, 2001. v. I. International society of explosive engineers, Cleveland, 2001. p.145-152.

VILELA, R. A. G.; IGUTI, A. M.; ALMEIDA, I. M. Culpa da vítima: um modelo para perpetuar a impunidade nos acidentes de trabalho. Cad. Saúde Pública, v.20, n.2, p. 570-579, 2004.

VILELA, R. A. Desafios da vigilância e da prevenção de acidentes do trabalho: A Experiência do programa de saúde do trabalhador de Piracicaba; Construindo prevenção e desvelando a impunidade. 2002. 318 p. Tese (Doutorado) - Faculdade de Ciências Médicas da Universidade Estadual de Campinas. Campinas, 2002.

WAGENAAR, W.A.; GROENEWEG, J. Accidents at sea: multiple causes and imposible consequences. International journal of man - Machine Studies, No. 27, 1987, p. 587598.

WOODS, D.D e COOK, R.I. Nine steps to move forward from error. Cognition technology and work. No. 4, 2002, p. 137-144. 
WRIGHT, C. Routine deaths: fatal accidents in the oil industry. Sociological review, No. 4, 1986 p. 265-289.

ZHANGTAO. Analysis on occupational-related safety fatal accident reports of China, 2001-2008. Safety science. No. 48, 2010, p. 640-642. 
ANEXOS 


\section{ANEXO A - MODELO DE RELATÓRIO DE ACIDENTE ELABORADO PELO MINISTÉRIO DE ENERGIA E MINAS DO PERU}

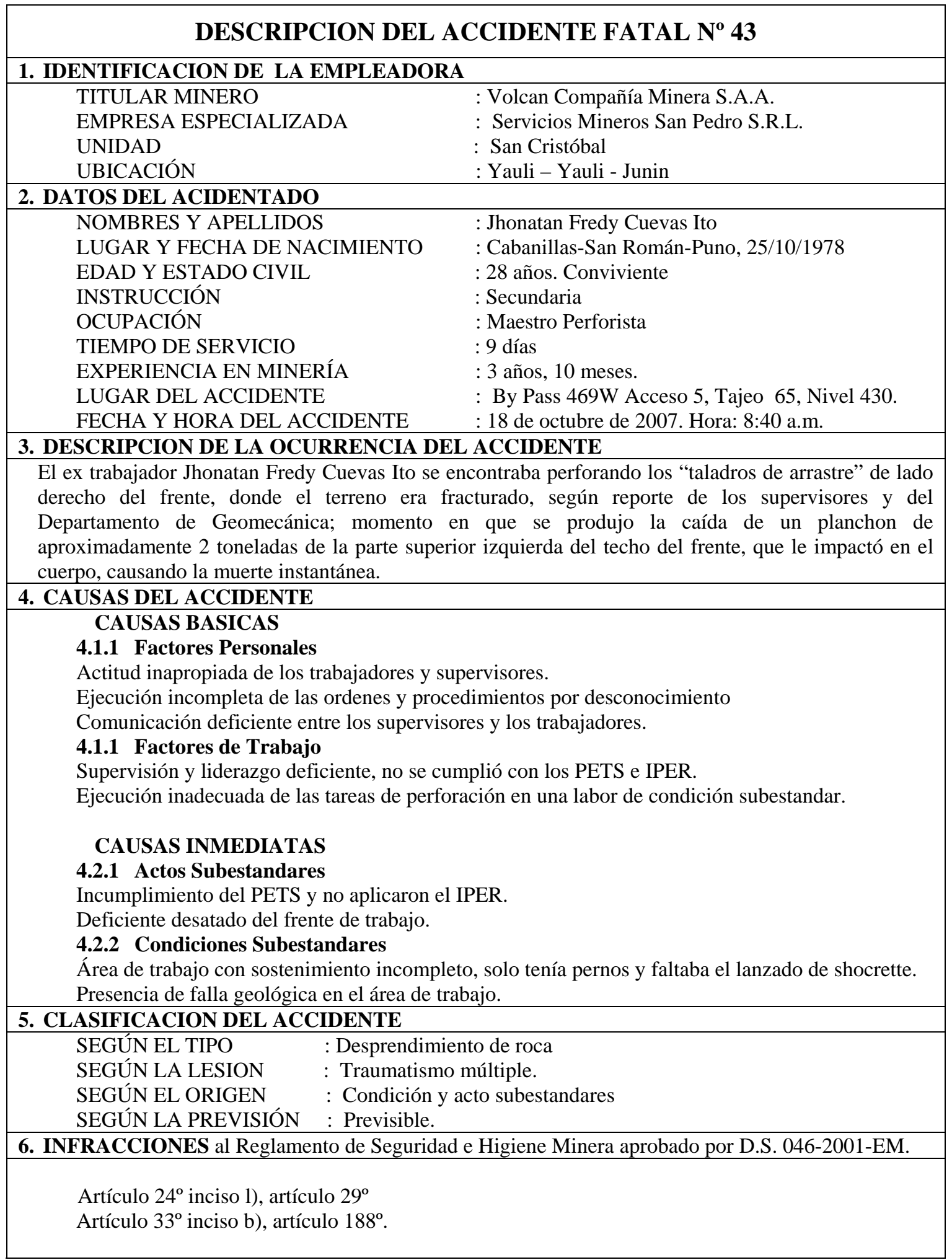



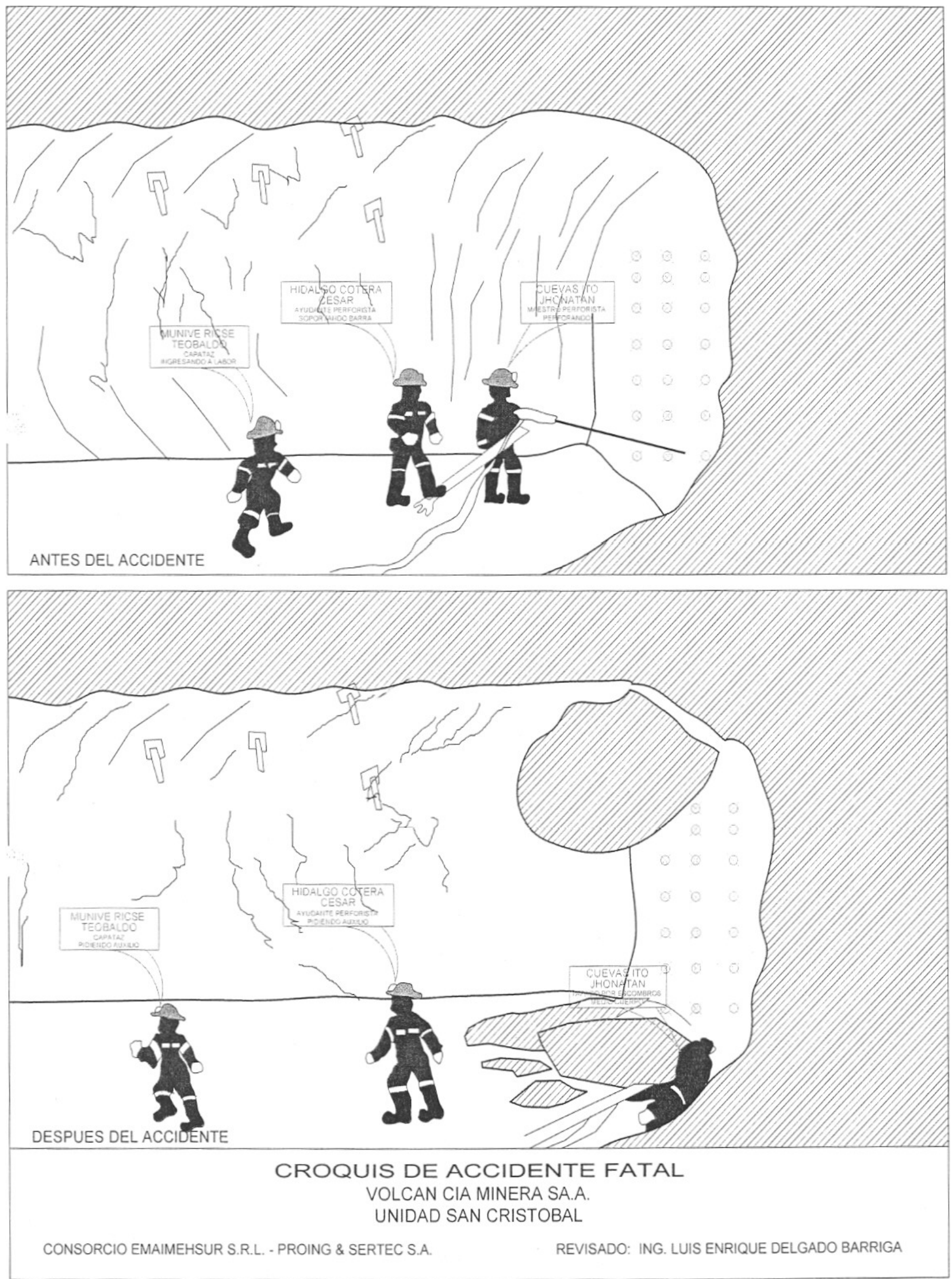
ANEXO B - MINAS E PROJETOS NO PERU (PERU, 2010)

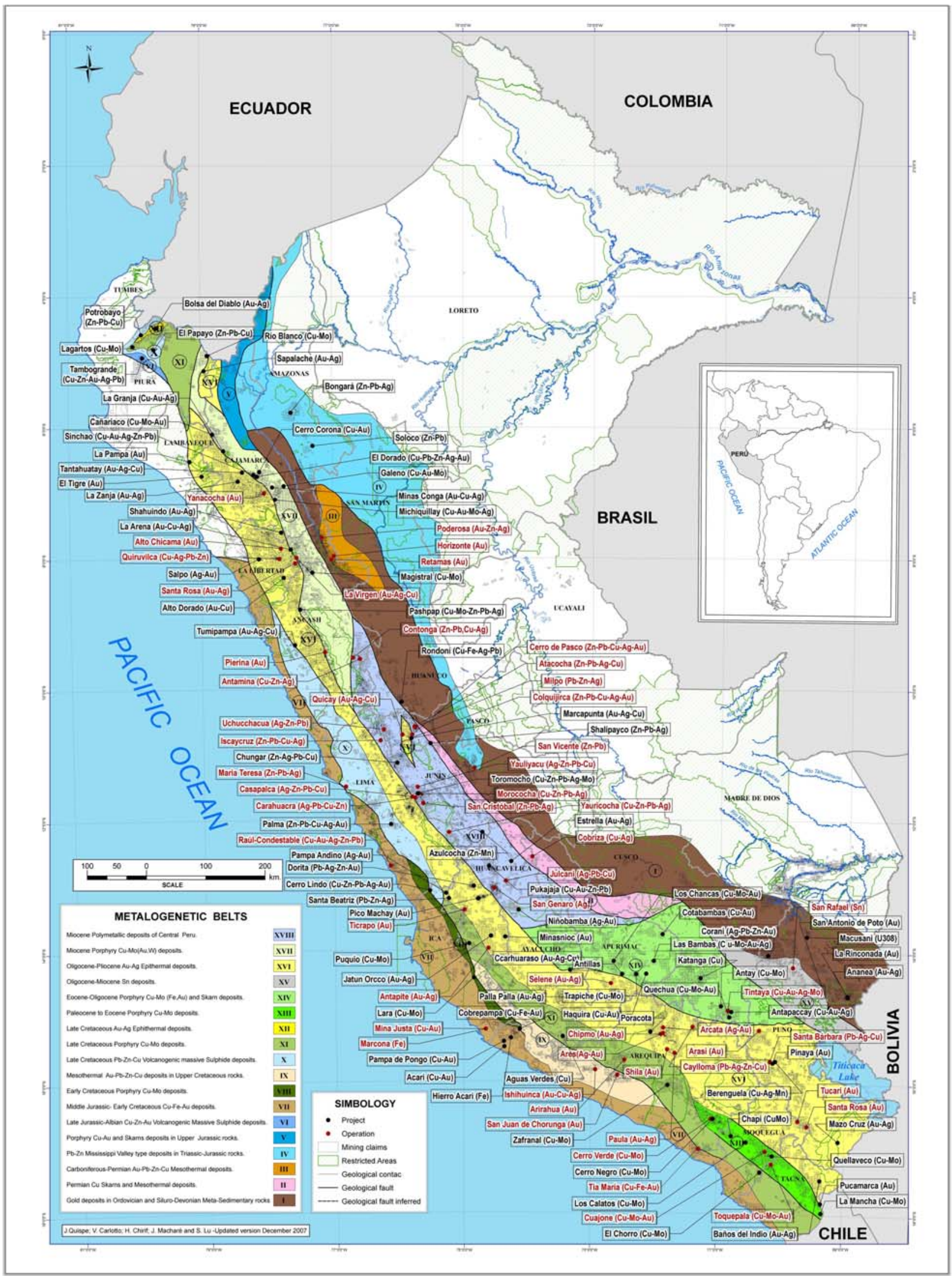




\section{APÊNDICES}




\section{APÊNDICE A - PRIMEIRA CARTA DE SOLICITAÇÃO DE INFORMAÇÃO A OSINERGMIN}

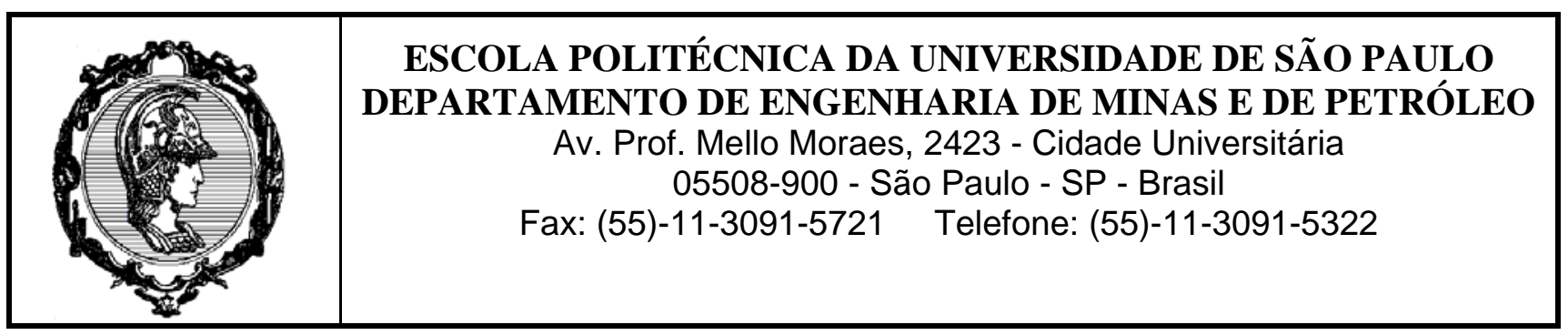

São Paulo 15 de noviembre de 2008.

Ing. Guillermo Shinno;

Gerente de Fiscalización Minera - Osinergmin.

De nuestra mayor consideración:

Deseando que todas sus actividades profesionales y personales estén desarrollándose de la mejor forma posible, venimos a través de esta carta a manifestarle lo siguiente.

Actualmente estamos desarrollando un trabajo de investigación a nivel de doctorado en el Departamento de Ingeniería de Minas e Petróleo de la Universidad de São Paulo - Brasil. El asunto abordado se refiere a "Acidentes fatais por queda de rochas na mineração do Peru”; para tal deseamos utilizar como fuente de información, el registro de accidentes fatales de los úlimos años.

Deseosos de obtener una respuesta favorable, nos despedimos de usted, expresándole nuestras mayores manifestaciuones de aprecio personal.

Atentamente:

Ing. Renán Collantes Candia; M.Sc.

Doctorando PMI/EPUSP

e-mail: Renan.candia@ poli.usp.br
Ing. Wildor Theodoro Hennies, Ph.D. Prof. Principal PMI/EPUSP e-mail: wildorth@usp.br 


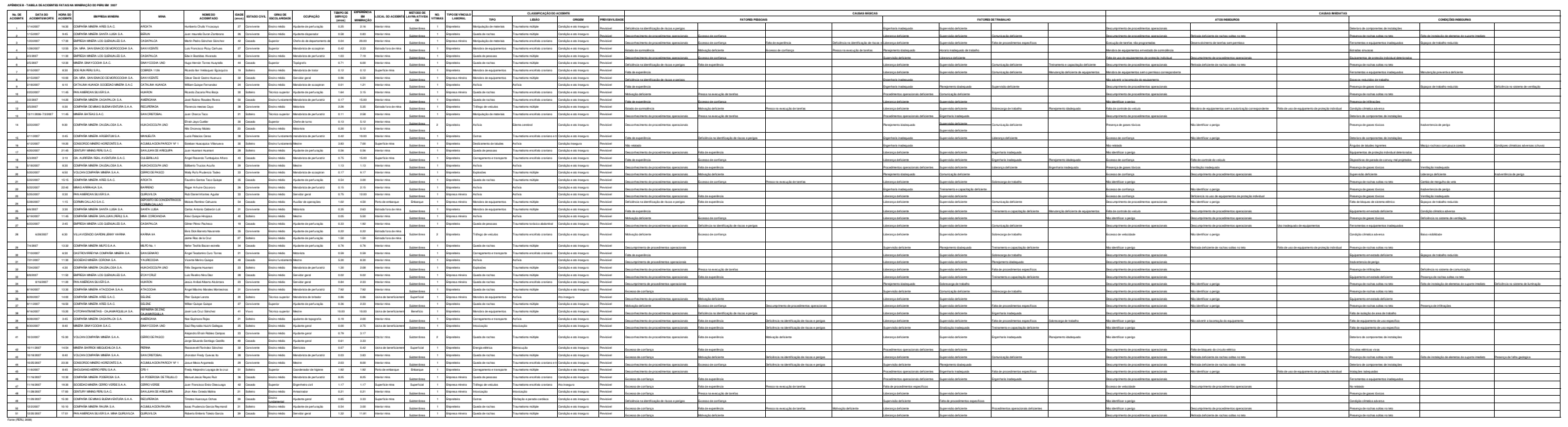




\section{APÊNDICE C - SEgUNDA CARTA DE SOLICITAÇÃO DE INFORMAÇÃO A OSINERGMIN}

\begin{tabular}{|c|c|} 
ESCOLA POLITÉCNICA DA UNIVERSIDADE DE SÃO PAULO \\
DEPARTAMENTO DE ENGENHARIA DE MINAS E DE PETRÓLEO \\
Av. Prof. Mello Moraes, 2423 - Cidade Universitária \\
$05508-900$ - São Paulo - SP - Brasil \\
Fax: (55)-11-3091-5721 Telefone: (55)-11-3091-5322
\end{tabular}

São Paulo 10 de junio de 2009.

Ing. Guillermo Shinno;

Gerente de Fiscalización Minera - Osinergmin.

De nuestra mayor consideración:

Deseando que todas sus actividades profesionales y personales estén desarrollándose de la mejor forma posible, venimos a través de esta carta a manifestarle lo siguiente.

Actualmente estamos desarrollando un trabajo de investigación a nivel de doctorado en el Departamento de Ingeniería de Minas e Petróleo de la Universidad de São Paulo - Brasil. El asunto abordado se refiere a "Uma contribuição ao estudo de acidentes fatais por queda de rochas - O caso da mineração Peruana"; para tal estamos utilizando como fuente de información, el registro de accidentes fatales del 2007, por ustedes permitido.

Dado que el numero de accidentes fatales registrados por caída de rocas en 2007 fue de 15 (quince) eventos; numero aun insuficiente para desarrollar un análisis estadístico consistente que nos permita llegar a conclusiones bien fundamentadas así como proponer un modelo confiable que explique los accidentes de esta naturaleza, le solicitamos la concesión de la información de accidentes fatales correspondientes al año 2008 (conforme formato de la descripción del accidente en anexo). Esta información nos permitirá llevar a buen termino la investigación en curso. Resaltamos que la información concedida por ustedes será utilizada estrictamente para propósitos académicos.

De esta forma reiteramos nuestras suplicas para la concesión de la información solicitada en formato electrónico (word o pdf), a fin de llevar a buen termino la investigación en curso, deseosos en que las conclusiones obtenidas en el trabajo en cuestión, contribuyan a una mejor gestión de la seguridad e salud ocupacional en la minería, la misma que permita una practica mas segura de esta importante actividad para la economía peruana.

Atentamente:

Ing. Renán Collantes Candia; M.Sc. Doctorando PMI/EPUSP e-mail: Renan.candia@ poli.usp.br
Ing. Wildor Theodoro Hennies, Ph.D. Prof. Principal PMI/EPUSP e-mail: wildorth@usp.br 


\section{APÊNDICE D - ESTIMATIVA DE COEFICIENTES DO MODELO DE REGRESÃO LOGÍSTICA}

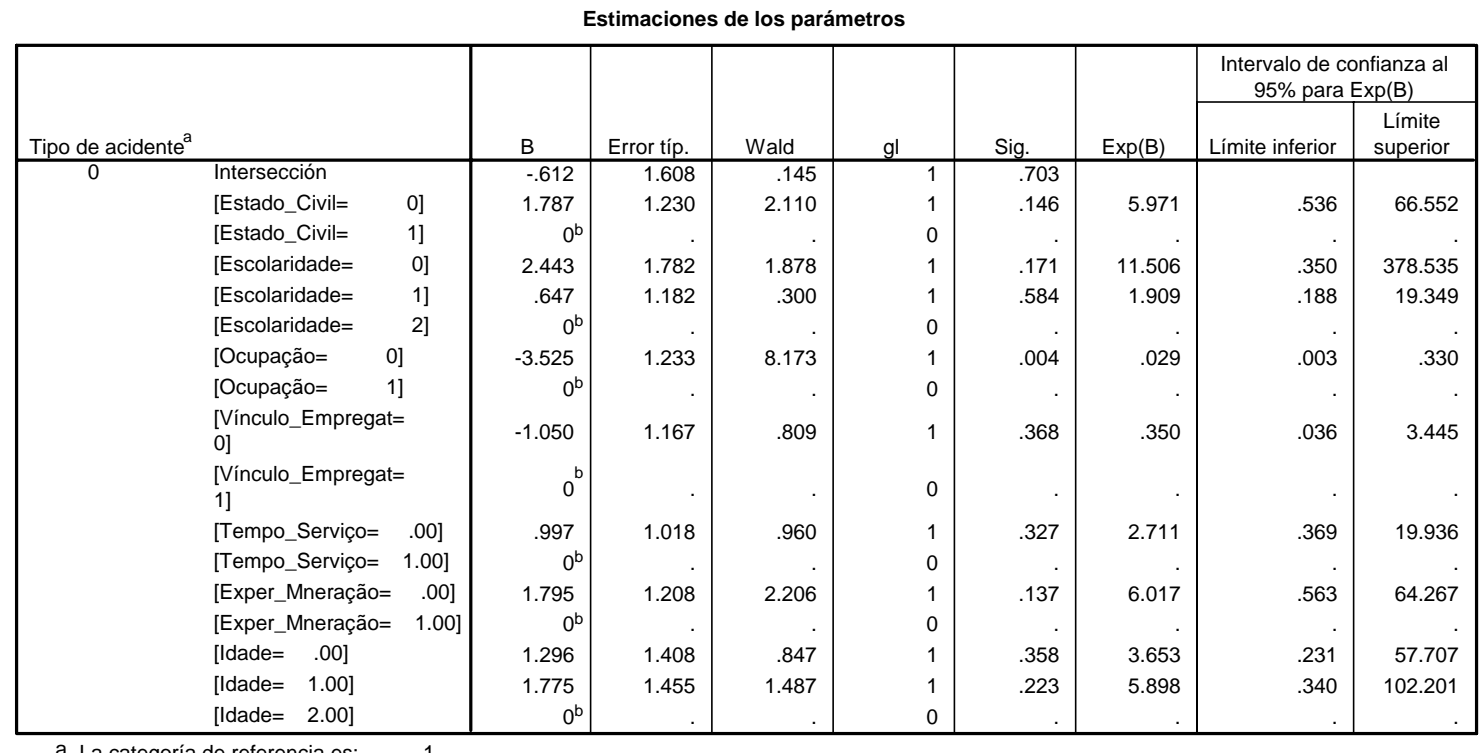

a. La categoría de referencia es: 1.

b. Este parámetro se ha establecido a cero porque es redundante.

\begin{tabular}{|c|c|c|c|c|c|c|c|c|c|c|}
\hline \multicolumn{11}{|c|}{ Estimaciones de los parámetros } \\
\hline \multirow[b]{2}{*}{ Tipo de acidente $^{a}$} & & & \multirow[b]{2}{*}{ B } & \multirow[b]{2}{*}{ Error típ. } & \multirow[b]{2}{*}{ Wald } & \multirow[b]{2}{*}{$\mathrm{gl}$} & \multirow[b]{2}{*}{ Sig. } & \multirow[b]{2}{*}{$\operatorname{Exp}(B)$} & \multicolumn{2}{|c|}{$\begin{array}{c}\text { Intervalo de confianza al } \\
95 \% \text { para } \operatorname{Exp}(B)\end{array}$} \\
\hline & & & & & & & & & Límite inferior & $\begin{array}{l}\text { Límite } \\
\text { superior }\end{array}$ \\
\hline \multirow[t]{7}{*}{0} & Intersección & & 1.011 & .529 & 3.650 & 1 & .056 & & & \\
\hline & [Estado_Civil= & 0] & 1.325 & .984 & 1.814 & 1 & .178 & 3.764 & .547 & 25.901 \\
\hline & [Estado_Civil= & 1] & $0^{\mathrm{b}}$ & & & 0 & & & & \\
\hline & [Ocupação= & 0] & -2.607 & .907 & 8.260 & 1 & .004 & .074 & .012 & .436 \\
\hline & [Ocupação= & 1] & $0^{\mathrm{b}}$ & & & 0 & & & & \\
\hline & [Exper_Mneração & $=.00]$ & 1.458 & .904 & 2.600 & 1 & 107 & 4.298 & .730 & 25.294 \\
\hline & [Exper_Mneração & $=1.00]$ & $0^{\mathrm{b}}$ & & & 0 & & & . & \\
\hline
\end{tabular}

a. La categoría de referencia es: 1.

b. Este parámetro se ha establecido a cero porque es redundante.

\begin{tabular}{|c|c|c|c|c|c|c|c|c|c|c|}
\hline \multirow[b]{2}{*}{ Tipo de acidente ${ }^{a}$} & & & \multirow[b]{2}{*}{ B } & \multirow[b]{2}{*}{ Error típ. } & \multirow[b]{2}{*}{ Wald } & \multirow[b]{2}{*}{$\mathrm{gl}$} & \multirow[b]{2}{*}{ Sig. } & \multirow[b]{2}{*}{$\operatorname{Exp}(B)$} & \multicolumn{2}{|c|}{$\begin{array}{l}\text { Intervalo de confianza al } \\
95 \% \text { para } \operatorname{Exp}(B)\end{array}$} \\
\hline & & & & & & & & & Límite inferior & $\begin{array}{c}\text { Límite } \\
\text { superior }\end{array}$ \\
\hline \multirow[t]{5}{*}{0} & Intersección & & 1.119 & .522 & 4.592 & 1 & .032 & & & \\
\hline & [Ocupação= & 0] & -2.477 & .874 & 8.025 & 1 & .005 & .084 & .015 & .466 \\
\hline & [Ocupação $=1$ & 1] & $0^{\mathrm{b}}$ & & & 0 & & & . & \\
\hline & [Exper_Mneração= & $=.00]$ & 1.690 & .877 & 3.711 & 1 & .054 & 5.420 & .971 & 30.252 \\
\hline & [Exper_Mneração= & $1.00]$ & $0^{b}$ & & & 0 & & & . & \\
\hline
\end{tabular}

a. La categoría de referencia es: 1.

b. Este parámetro se ha establecido a cero porque es redundante. 


\section{APÊNDICE E - APLICAÇÃO DE ENTREVISTA NA MINA CONDESTABLE}

\section{INTRODUÇÃO}

A Companhia Mineira "Condestable" é uma empresa dedicada ao beneficiamento e à comercialização de concentrados de cobre a partir de minerais de calcopirita e bornita. Esta empresa foi fundada em novembro de 1962 por capitais privados e, em 1976, passou a ser propriedade do estado peruano. Em 1992, foi a primeira empresa pública a ser privatizada e, em 1997, foram adquiridas $75,46 \%$ das ações pelo grupo "Trafigura". Esta é uma empresa que está no mercado de metais e concentrados não ferrosos, petróleo e outros a nível global com mais de 50 escritórios em 30 países do mundo.

A mina Condestable se encontra no litoral peruano no distrito de Mala, província de Cañete e departamento de Lima. Está localizada nas coordenadas geográficas $76^{\circ} 35^{\prime} 30^{\prime \prime}$ longitude oeste e $12^{\circ} 42^{\prime}$ '02" latitude sul. A distância de Lima à mina é de $90 \mathrm{Km}$ e seu acesso se dá por meio da rodovia "Panamericana Sur". A Figura 1 mostra sua localização.

As frentes de lavra da mina estão compreendidas entre os níveis -250 e +372 . Geomorfologicamente, são reconhecidas duas unidades de extensão local. A primeira representada pela acumulação de material detrítico que preencheu as quebradas atualmente secas e as dobras baixas do flanco ocidental do batolito litorâneo caracterizado por um relevo composto por montanhas de flancos empinados, em rocha granítica e vulcânica - sedimentar, relacionadas ao batolito do litoral peruano.

A lavra se faz usando o método de sub níveis com furos longos em anel e paralelo (sublevel stoping) com um custo aproximado de 2,00 dólares americanos por tonelada em rocha competente de resistência média de 120 MPa (QUISPE, 2008). Este método caracteriza-se por sua grande produtividade, devido à lavra realizar-se na maior parte dentro do corpo do minério (LLANQUE e NAVARRO, 1999). 


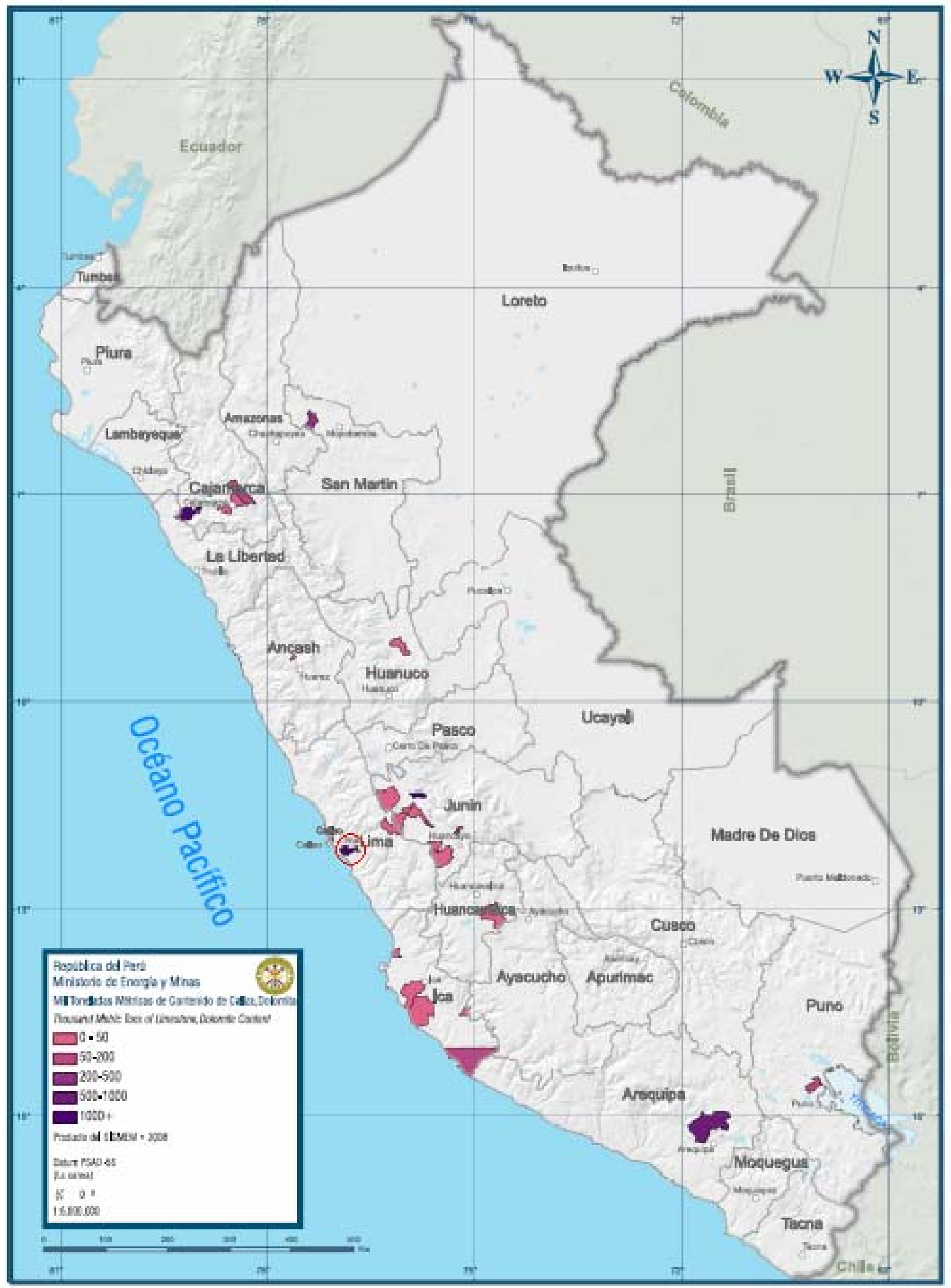

Figura 1 - Localização da mina Condestable (PERU, 2008) 
Os corpos ou estruturas são lavrados dividindo-se em painéis de 20 e 40 metros de largura e altura respectivamente. A lavra propriamente dita se efetua desde os níveis para estabelecer os intervalos verticais. Os subníveis são desenvolvidos entre os níveis principais; o minério é desmontado com furos longos de 15 a 20 metros e $64 \mathrm{~mm}\left(21 / 2^{\prime \prime}\right)$ de diâmetro desde os subníveis, e descem por gravidade, sendo recuperados pelos draw points para depois serem transportados para a superfície.

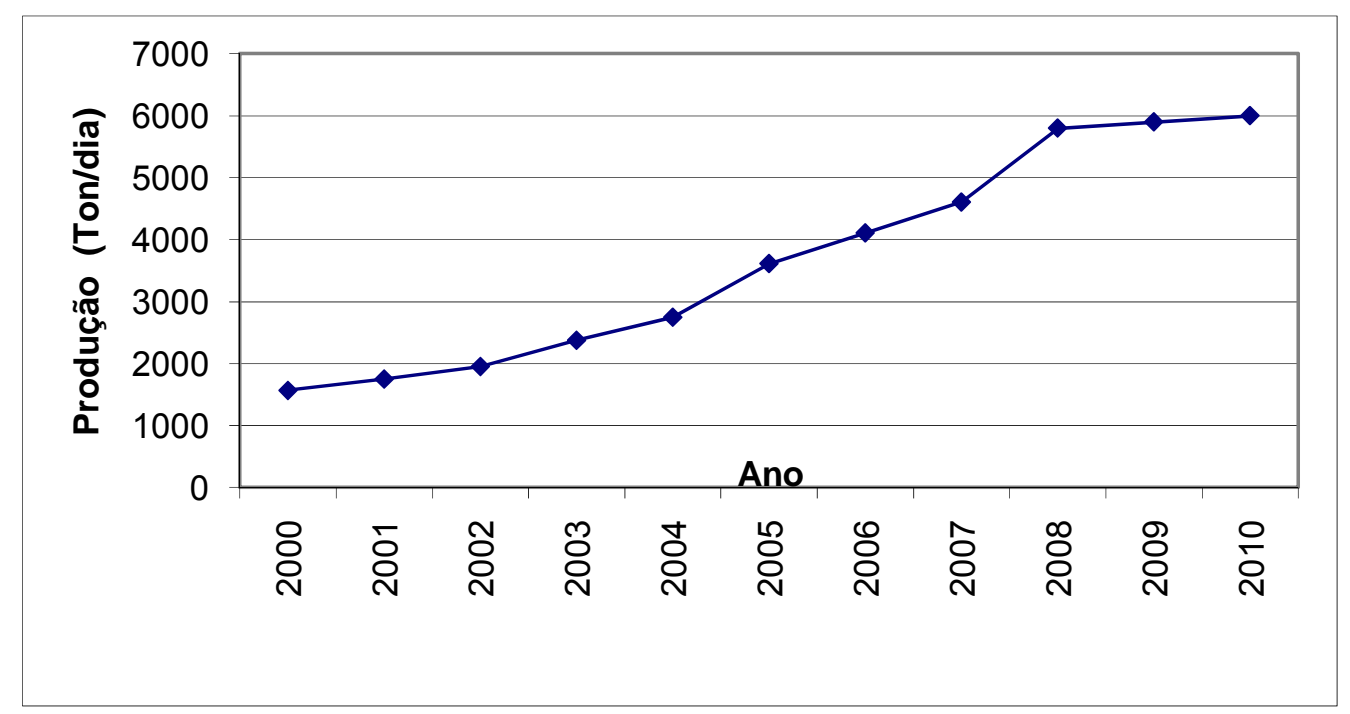

Figura 2 - Produção diária de minério por ano (CONDESTABLE, 2010)

De 2000 a 2010, a mina Condestable incrementou sua produção em aproximadamente $277 \%$, como mostra a Figura 2 . Assim, em 2000 , a produção diária era da ordem de 1500 toneladas, enquanto que, em 2008, foi de aproximadamente 6000 toneladas com um teor médio de $1,25 \%$ de cobre. Isto foi o resultado dos sucessivos projetos de ampliação da produção ao longo dos últimos anos.

A companhia mineira Condestable desde 2006 tem implementado um Sistema Integrado de Riscos SIGER - Condestable, que the permitiu melhorar sustentavelmente seus indicadores de desempenho na segurança. A Tabela 1 mostra os indicadores de desempenho da segurança em 2010. Observa-se que, nesse ano, com relação aos acidentes, aconteceram 98 triviais, 33 incapacitantes e nenhum fatal, representando 731 dias perdidos para um total de 4.298 .913 horas homem trabalhadas, que resultaram finalmente em um índice de frequência de 7,68, um índice de severidade de 170,04 e um índice de acidentabilidade de 1,31. 
Tabela 1 - Indicadores de desempenho de segurança da companhia mineira Condestable em

\begin{tabular}{lcc}
\multicolumn{3}{c}{$\mathbf{2 0 1 0}$} \\
\multicolumn{1}{c}{ Acidentes } & Acumulado 2010 & Meta \\
\hline Triviais & 98 & \\
Incapacitantes & 33 & \\
Fatais & 0 & \\
Dias perdidos & 731 & \\
Horas homem trabalhadas & 4.298 .913 & 5 \\
Índice de frequência $(\mathrm{IF})^{1}$ & 7,68 & 100 \\
Índice de severidade $(\mathrm{IS})^{2}$ & 170,04 & 0,5 \\
${\text { Índice de acidentabilidade }(\mathrm{IA})^{3}}_{\text {Fonte (CONDESTABLE, 2010) }}$ & 1,31 &
\end{tabular}

A Figura 3 mostra os acidentes incapacitantes por tipo, que aconteceram em 2010. Percebe-se que a queda de rochas é o tipo de acidente mais representativo, seguido pelos acidentes por queda de pessoas, a manipulação de materiais, entre outros.

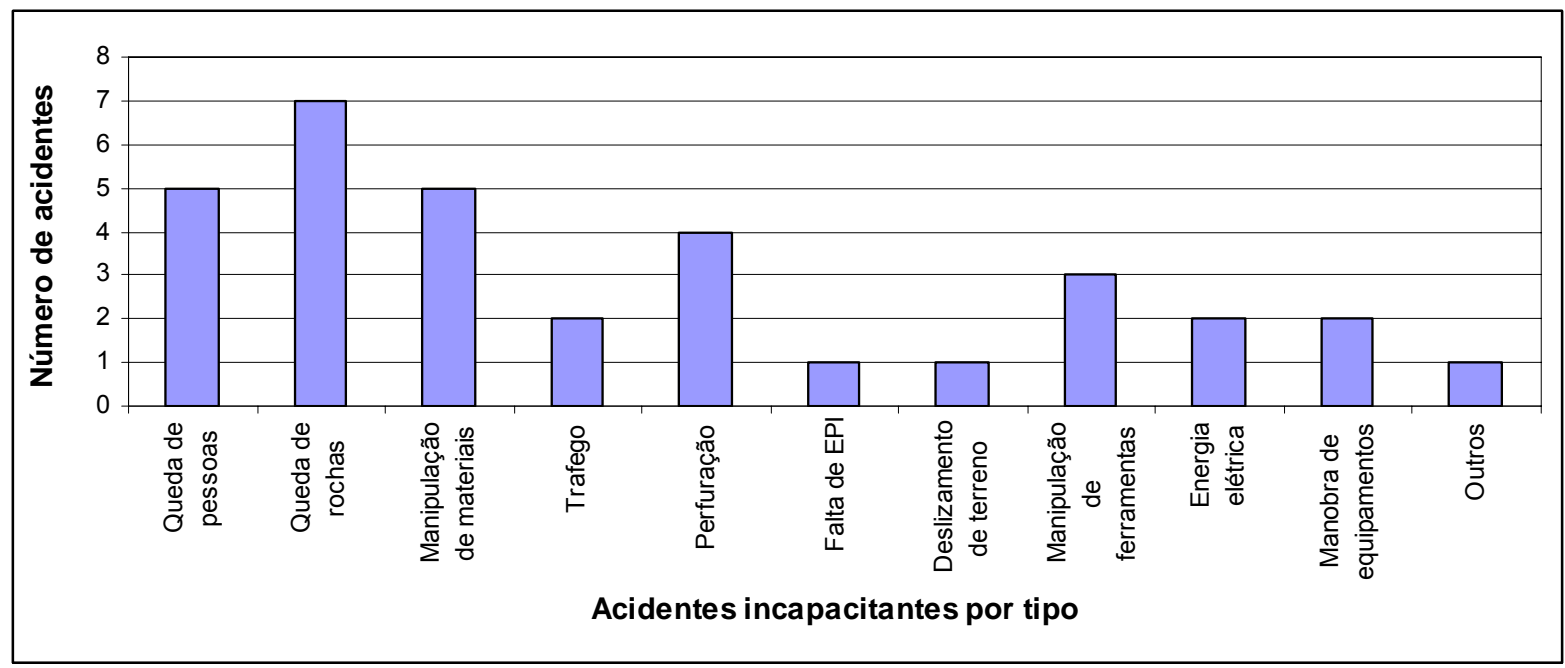

Figura 3 - Acidentes incapacitantes por tipo, na mina Condestable em 2010 (CONDESTABLE, 2010)

${ }^{1} I F=\frac{\text { No.Acidentes }(\text { fatais }+ \text { incapac } .) * 1.000 .000}{\text { HorasHomemTrabalhadas }}$

${ }^{2}$ IS $=\frac{\text { No.DiasPerdidosOuDebitados } * 1.000 .000}{\text { HorasHomemTrabalhadas }}$

${ }^{3} I A=\frac{I F * I S}{1.000}$ 


\section{OBJETIVO}

O presente documento tem por objetivo apresentar os resultados da entrevista aplicada a trabalhadores mineiros, visando a conhecer suas características pessoais, comparando-as com as características das vítimas de acidentes fatais na mineração subterrânea peruana em 2007. A aplicação do questionário tem também por objetivo caracterizar o desenvolvimento de tarefas em operações de lavra subterrânea no que diz respeito aos fatores pessoais e de trabalho.

\section{METODOLOGIA}

Para o desenvolvimento do presente estudo, elaborou-se um questionário, o mesmo que deveria ser aplicado em uma mina peruana subterrânea. Após solicitação formal ao gerente de operações da mina Condestable, Engeheiro Johny Orihuela, por meio do Engenheiro Percy Martel, superintendente de segurança e meio ambiente da mina, foi permitida a visita em questão.

O questionário foi desenvolvido a partir dos resultados de fatores pessoais e de trabalho, identificados no estudo de causas de acidentes fatais por queda de rochas na mineração subterrânea do Peru em 2007. A informação para o estudo em referência desenvolveu-se a partir do registro de acidentes fatais concedido por OSINERGMIN.

O questionário estava estruturado em duas partes. A primeira referia-se às características pessoais do trabalhador (nome, idade, data de nascimento, idade, escolaridade, estado civil, experiência em mineração, tempo de serviço, função e vínculo empregatício. Essa primeira parte permitiria relacionar as características pessoais das vítimas por acidentes a nível nacional com as características dos trabalhadores entrevistados.

A segunda parte estava conformada pelo questionário propriamente dito, composto por 41 perguntas cujas respostas do trabalhador deveriam ser "sim" ou "não", com exceção da pergunta P39 (considera que a capacitação dá mais importância à produção?) em que apareceu como resposta a situação em que o trabalhador considera que a capacitação dá igual importância tanto à produção quanto à segurança. 
A aplicação da entrevista foi feita a 60 funcionários que trabalhavam ou no período diurno ou no noturno. A duração do turno era de 12 horas. Aplicou-se esta entrevista durante a visita técnica à mina entre os dias 25 e 29 de outubro de 2010 , como mostra a Figura 4. A análise estatística foi feita com os softwares comerciais "Statistical Package for the Social Science" SPSS ${ }^{\circ} 15.0$ da "Statistical Product and Service Solutions"; assim como o Excel® da "Microsoft Corporation". Os resultados são apresentados em forma de Tabelas e Figuras.

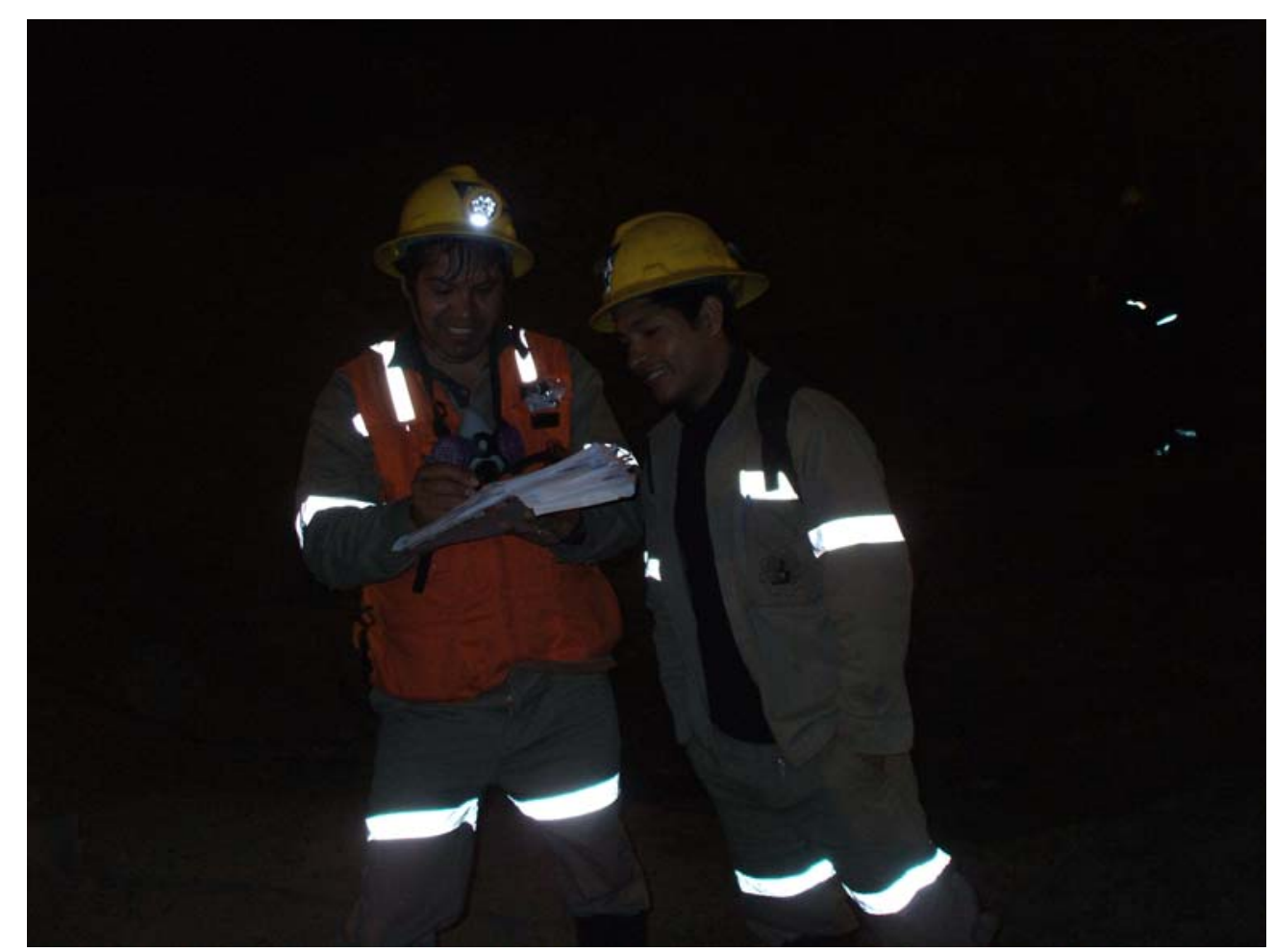

Figura 4 - Aplicação de entrevista a trabalhador na mina Condestable.

\section{APRESENTAÇÃO DE RESULTADOS}

\subsection{CARACTERÍSTICAS PESSOAIS DE TRABALHADORES ENTREVISTADOS}

A idade dos trabalhadores entrevistados variava entre 22 e 54 anos, com uma média de 32,92 anos e um desvio padrão de 6,95 anos. Já a idade das vítimas em acidentes fatais na mineração subterrânea em 2007 variava entre 19 e 50 anos, com uma média aritmética de 31,02 anos e desvio padrão de 7,95 anos. A Figura 5 mostra a distribuição percentual de idades agrupadas em intervalos de idade. 


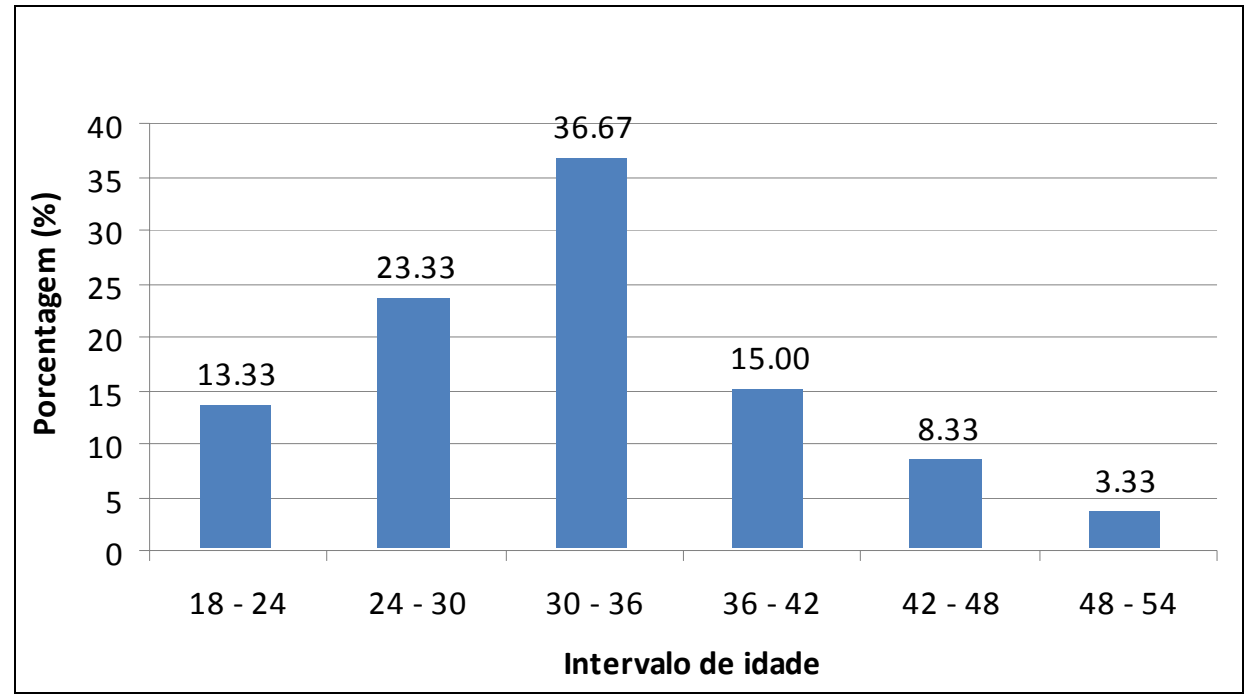

Figura 4 - Distribuição percentual da idade de trabalhadores entrevistados por intervalo de idade

A experiência em mineração dos trabalhadores entrevistados estava compreendida entre 1 e 33 anos, com média de 8,10 anos e desvio padrão de 6,40 anos. Já as vítimas fatais em acidentes em mineração subterrânea do Peru em 2007 tinham uma experiência compreendida entre 0,12 a 20 anos, com média de 4,95 e desvio padrão de 4,42 anos. A Figura 5 mostra a distribuição percentual da experiência dos trabalhadores entrevistados agrupados em intervalos.

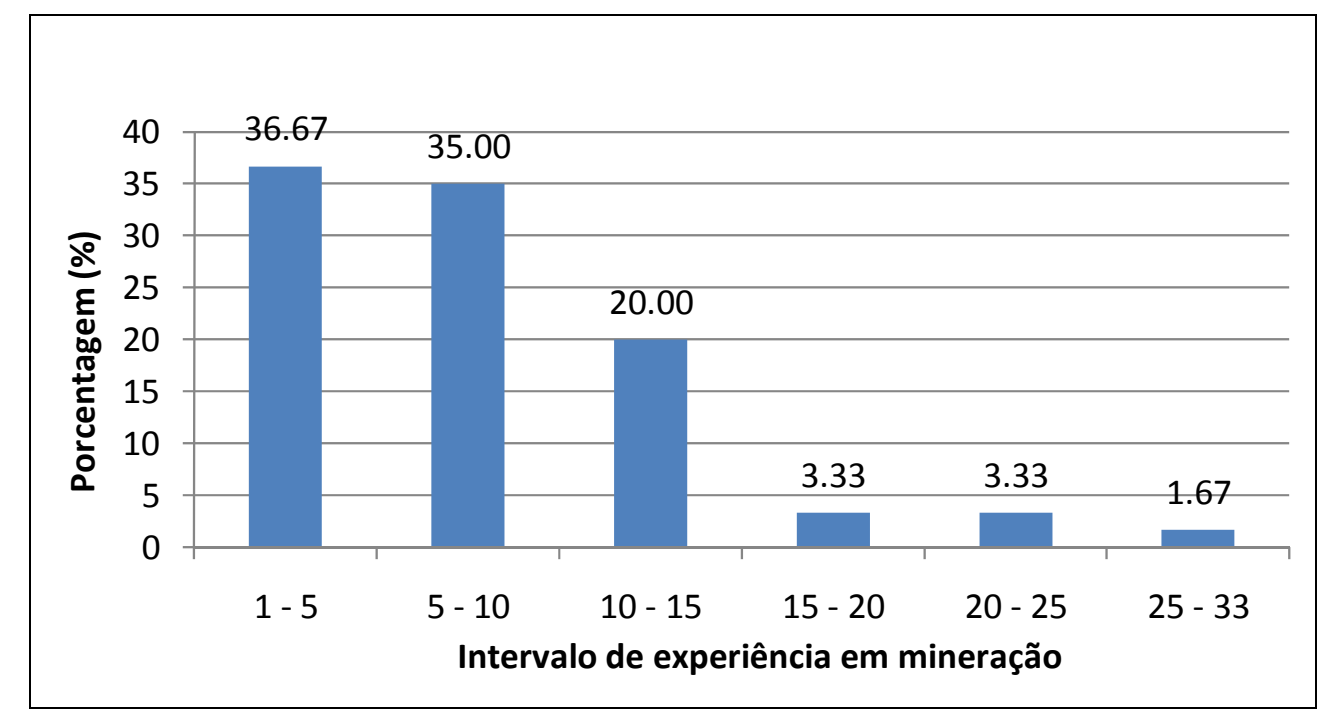

Figura 5 - Distribuição percentual da experiência em mineração de trabalhadores entrevistados

O tempo de serviço dos trabalhadores entrevistados estava compreendido entre um dia e 21 anos, com média de 5,37 e desvio padrão de 4.44 anos. Já o tempo de 
serviço de vítimas fatais na mineração subterrânea em 2007 na mina onde aconteceu o acidente estava compreendido entre um dia e 8,25 anos, com média de 1,07 anos e desvio padrão de 1,77 anos. A Figura 6 mostra a distribuição percentual do tempo de serviço dos trabalhadores agrupados por intervalo de classe.

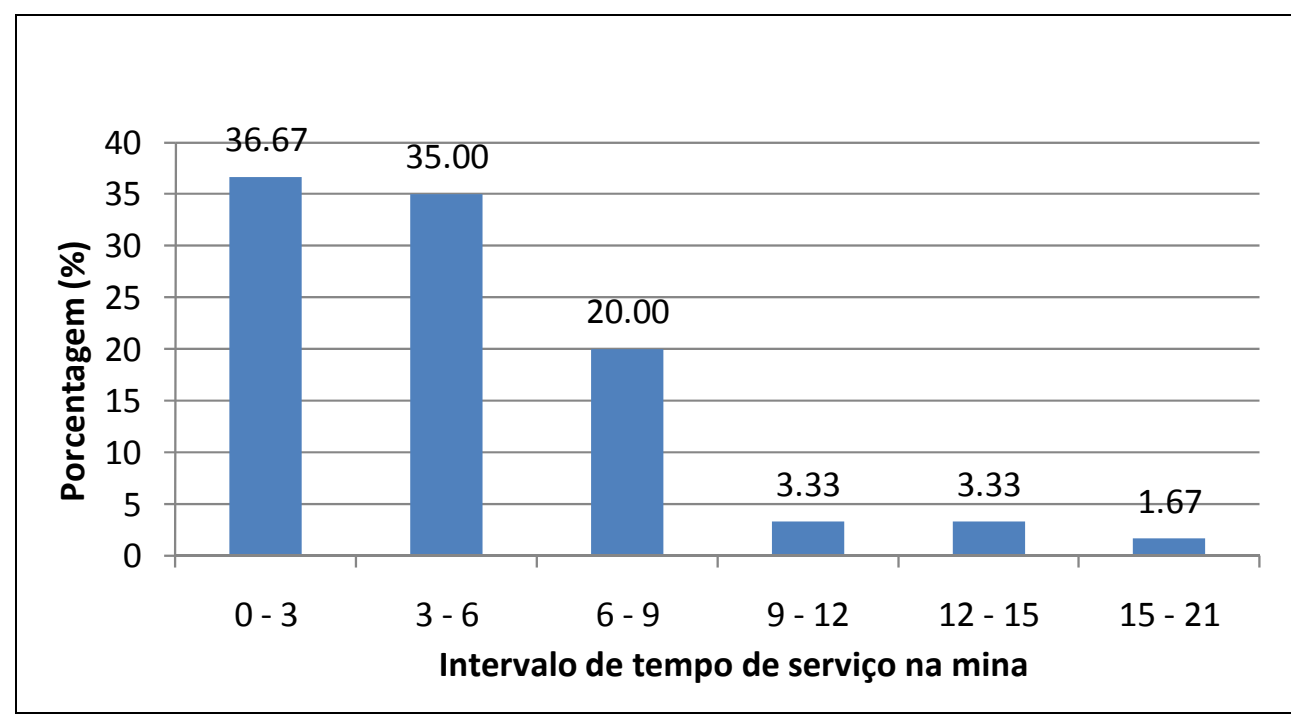

Figura 6 - Distribuição percentual do tempo de serviço na mina Condestable de trabalhadores entrevistados

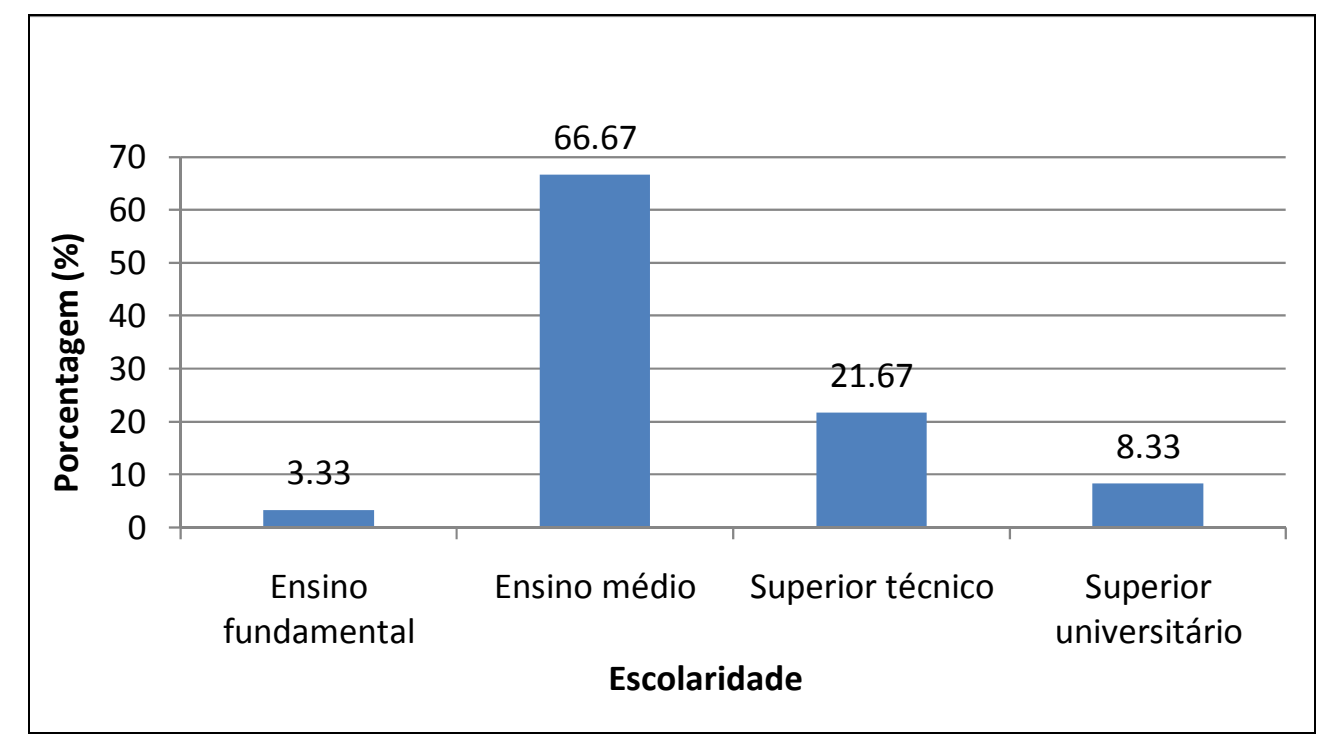

Figura 7 - Distribuição percentual da escolaridade de trabalhadores entrevistados

A Figura 7 mostra a escolaridade dos trabalhadores entrevistados. Observase que $70 \%$ dos trabalhadores tinham uma escolaridade de até ensino médio; os $30 \%$ restantes tinham ensino superior técnico ou universitário. Já a escolaridade das vítimas fatais em acidentes na mineração subterrânea do Peru em 2007 estava 
distribuída da seguinte maneira: 85,4 \% tinham escolaridade de até ensino médio e $14,6 \%$ possuíam o ensino superior técnico ou universitário.

A Figura 8 mostra a distribuição percentual do estado civil dos trabalhadores entrevistados. Pode-se observar que $81,67 \%$ dos entrevistados eram casados ou conviventes, enquanto que os $18,33 \%$ restantes eram solteiros. Já $75 \%$ das vítimas fatais em acidentes na mineração subterrânea do Peru eram casados ou conviventes, enquanto que os $25 \%$ restantes eram solteiros.

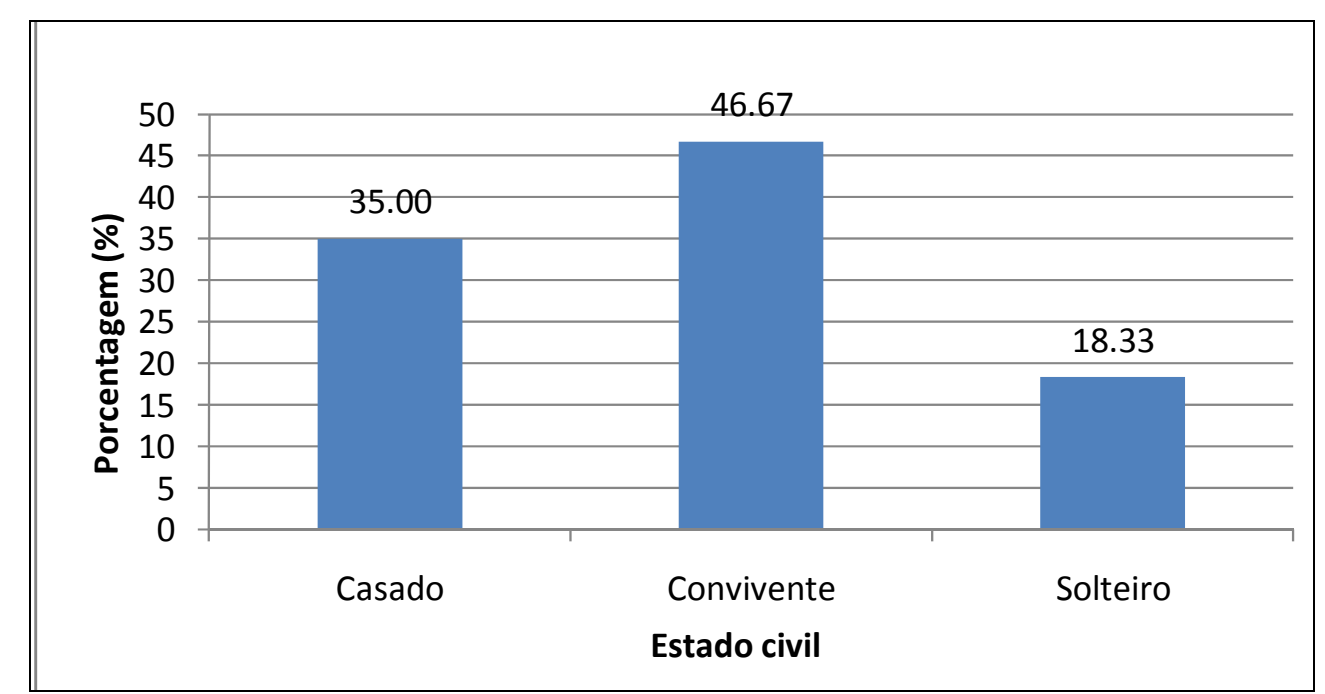

Figura 8 - Distribuição percentual do estado civil dos trabalhadores entrevistados

A Figura 9 mostra a distribuição percentual do vínculo empregatício dos trabalhadores entrevistados. Observa-se que $86,67 \%$ de trabalhadores pertenciam às empresas mineiras terceirizadas (empreiteiras), enquanto que $13,33 \%$ às empresas mineiras proprietárias dos empreendimentos. No cenário das vítimas de acidentes em mineração subterrânea em 2007, 79,2\% estavam vinculadas às empresas terceirizadas, enquanto que os $20 \%$ restantes pertenciam às empresas proprietárias das minas.

A Figura 10 mostra a distribuição percentual dos trabalhadores entrevistados. Observa-se que trabalhadores que desempenhavam a função de ajudantes de perfuração e manobristas de perfuratrizes em conjunto representavam 46,67\%. No cenário das vítimas em acidentes fatais na mineração subterrânea do Peru, em 2007, os ajudantes de perfuração e operadores de perfuratriz em conjunto representavam $41,6 \%$ do total de casos. 


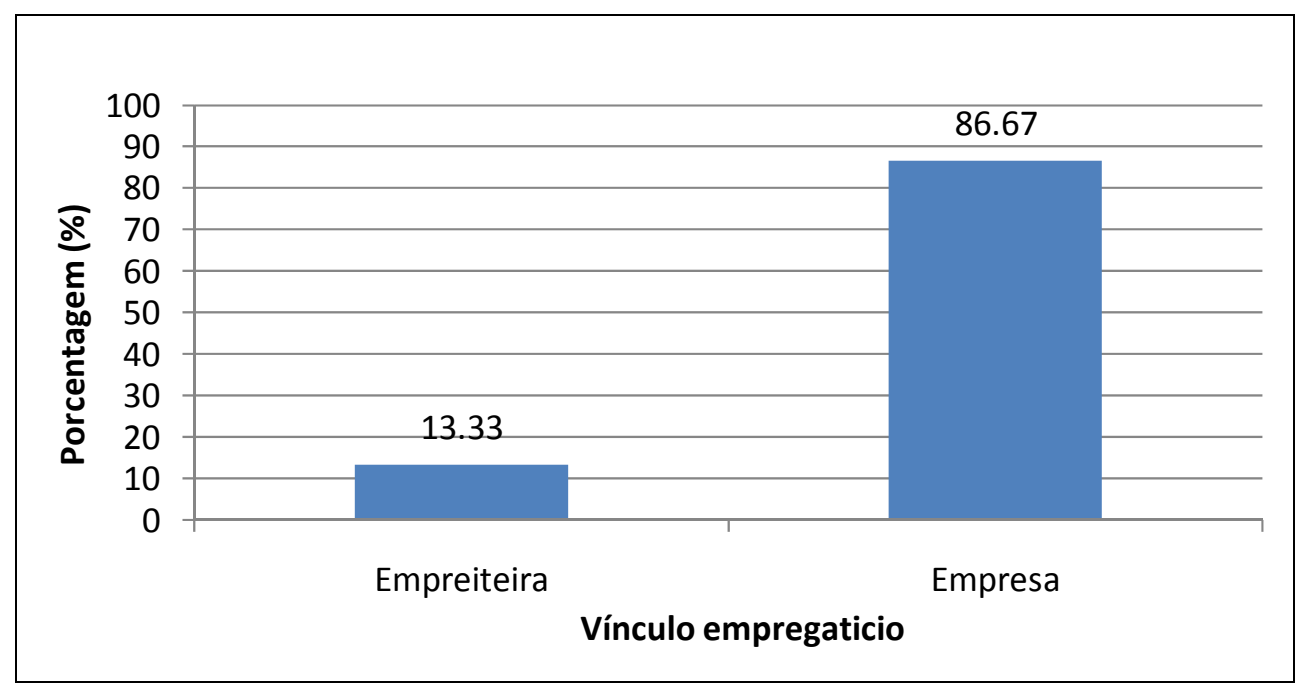

Figura 9 - Distribuição percentual de trabalhadores entrevistados segundo o vínculo empregatício

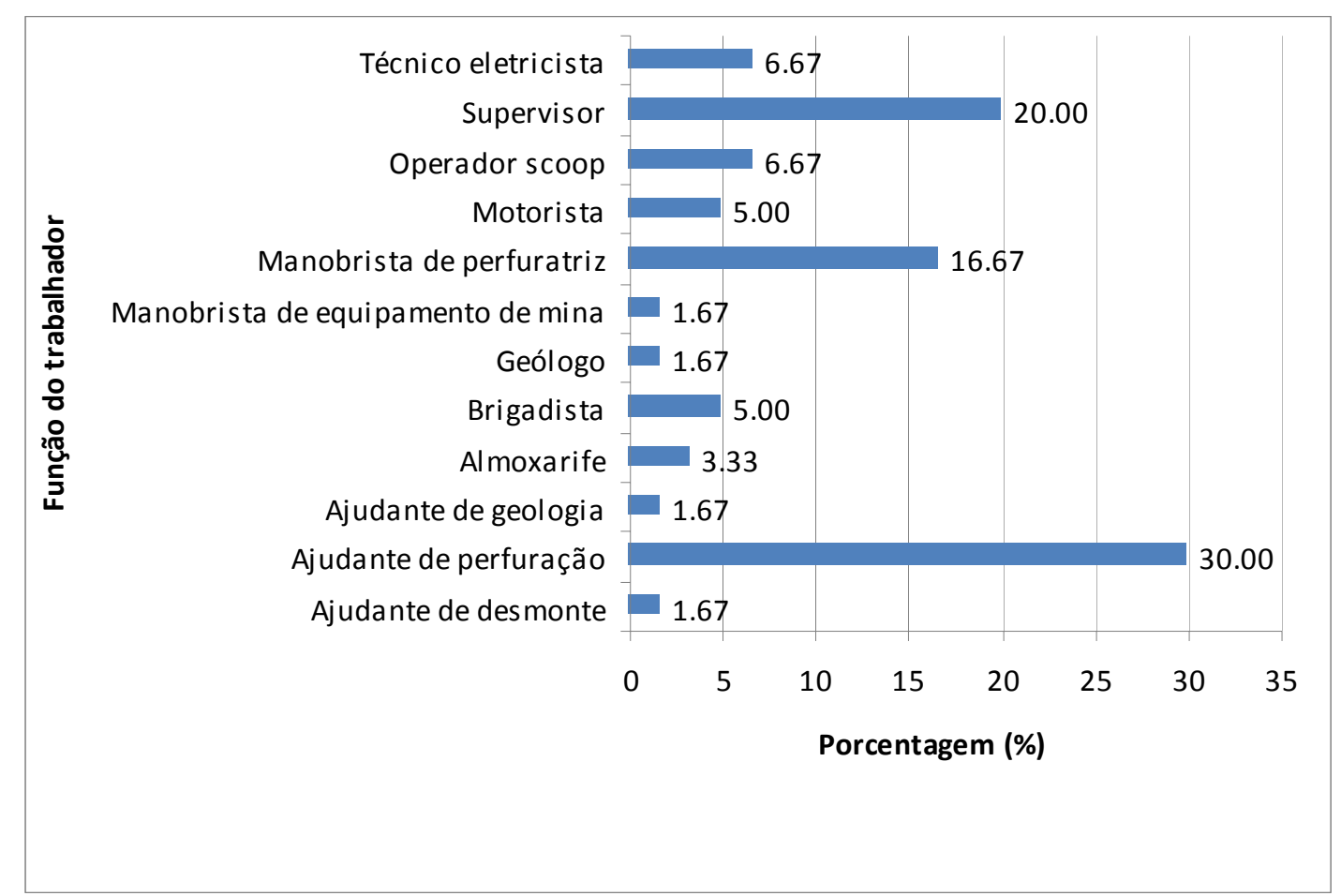

Figura 10 - Distribuição percentual de trabalhadores entrevistados segundo a função desempenhada na mina

A Tabela 2 mostra os resultados da entrevista realizada na mina Condestable, a mesma que foi aplicada de forma aleatória a 60 trabalhadores, tanto de turnos noturnos como diurnos. Os trabalhadores entrevistados desempenhavam principalmente suas funções em operações de lavra. 


\section{Tabela 2 - Resultados do questionário na mina Condestable - Peru}

\begin{tabular}{|c|c|c|c|c|c|c|c|}
\hline \multirow{2}{*}{ Cod. Perg. } & \multirow{2}{*}{ Pergunta } & \multicolumn{3}{|c|}{ Frequência absoluta } & \multicolumn{3}{|c|}{ Frequência relativa (\%) } \\
\hline & & Sim & Não & Ambos & Sim & Não & Ambos \\
\hline P1 & Considera seu trabalho de risco? & 59 & 1 & & 98.33 & 1.67 & \\
\hline P2 & Já enfrentou uma situação de risco? & 50 & 10 & & 83.33 & 16.67 & \\
\hline P3 & Já presenciou um acidente de trabalho? & 26 & 34 & & 43.33 & 56.67 & \\
\hline P4 & Considera-se um trabalhador experiente? & 52 & 8 & & 86.67 & 13.33 & \\
\hline P5 & Considera-se um trabalhador motivado? & 54 & 6 & & 90.00 & 10.00 & \\
\hline P6 & Considera que a empresa motiva seus trabalhadores? & 34 & 26 & & 56.67 & 43.33 & \\
\hline P7 & Você tem interesse em aprender novas técnicas e procedimentos de trabalho? & 60 & 0 & & 100.00 & 0.00 & \\
\hline P8 & Conhece os procedimentos de trabalho seguro? & 59 & 1 & & 98.33 & 1.67 & \\
\hline P9 & Considera compreensiveis e suficientes os procedimentos de trabalho seguro? & 50 & 10 & & 83.33 & 16.67 & \\
\hline P10 & Sabe identificar um perigo (rocha solta)? & 59 & 1 & & 98.33 & 1.67 & \\
\hline P11 & Considera a supervisão necessária? & 53 & 7 & & 88.33 & 11.67 & \\
\hline $\mathrm{P} 12$ & Considera o tempo de supervisão suficiente? & 47 & 13 & & 78.33 & 21.67 & \\
\hline P13 & Considera que a supervisão é feita corretamente? & 40 & 20 & & 66.67 & 33.33 & \\
\hline P14 & Considera o supervisor como um profissional experiente? & 50 & 10 & & 83.33 & 16.67 & \\
\hline P15 & Considera o supervisor como um profissional comprometido com a empresa? & 55 & 5 & & 91.67 & 8.33 & \\
\hline $\mathrm{P} 16$ & Considera que o supervisor está sobrecarregado de trabalho? & 24 & 36 & & 40.00 & 60.00 & \\
\hline P17 & Considera que o supervisor é um líder? & 48 & 12 & & 80.00 & 20.00 & \\
\hline P18 & Considera que o supervisor é um profissional motivado? & 54 & 6 & & 90.00 & 10.00 & \\
\hline P19 & Considera que os supervisores valorizam seu trabalho? & 43 & 17 & & 71.67 & 28.33 & \\
\hline $\mathrm{P} 20$ & Considera que a comunicação entre colegas é clara? & 49 & 11 & & 81.67 & 18.33 & \\
\hline P21 & Considera que seu supervisor the designa a tarefa de forma clara e compreensivel? & 58 & 2 & & 96.67 & 3.33 & \\
\hline $\mathrm{P} 22$ & Em caso de dúvida, você pergunta a seu colega ou supervisor? & 59 & 1 & & 98.33 & 1.67 & \\
\hline P23 & Você presta atenção aos diálogos diários de segurança? & 60 & 0 & & 100.00 & 0.00 & \\
\hline P24 & Você presta atenção aos cartazes de aviso na empresa? & 58 & 2 & & 96.67 & 3.33 & \\
\hline P25 & Você é informado sobre o acontecido no turno anterior? & 53 & 7 & & 88.33 & 11.67 & \\
\hline P26 & Compreende os manuais de ferramentas e equipamentos que utiliza? & 57 & 3 & & 95.00 & 5.00 & \\
\hline P27 & Considera a sinalização na mina clara e compreensível? & 55 & 5 & & 91.67 & 8.33 & \\
\hline P28 & Considera suficientes os recursos que a empresa lhe oferece para desenvolver suas atividades de forma satisfatória? & 39 & 21 & & 65.00 & 35.00 & \\
\hline P29 & Considera que existe pressão por parte dos supervisores para atingir os programas de produção? & 23 & 37 & & 38.33 & 61.67 & \\
\hline P30 & Considera sua equipe de trabalho suficiente para atingir os programas de produção? & 50 & 10 & & 83.33 & 16.67 & \\
\hline P31 & Considera que existem paradas por falha nos equipamentos? & 50 & 10 & & 83.33 & 16.67 & \\
\hline P32 & Considera que existem paradas porque os materiais não chegam a tempo na frente de trabalho? & 40 & 20 & & 66.67 & 33.33 & \\
\hline P33 & Antes de começar suas atividades nesta mina, você recebeu treinamento e capacitação? & 55 & 5 & & 91.67 & 8.33 & \\
\hline P34 & Considera que o treinamento e a capacitação para desenvolver sua função são suficientes? & 39 & 21 & & 65.00 & 35.00 & \\
\hline P35 & Você recebeu treinamento prático? & 51 & 9 & & 85.00 & 15.00 & \\
\hline P36 & Considera a pessoa que o treina como capacitada para tal? & 49 & 11 & & 81.67 & 18.33 & \\
\hline P37 & Considera suficiente o tempo de capacitação? & 42 & 18 & & 70.00 & 30.00 & \\
\hline P38 & A linguagem utilizada na capacitação é compreensível? & 57 & 3 & & 95.00 & 5.00 & \\
\hline P39 & Considera que a capacitação dá mais importância à produção? & 16 & 37 & 7 & 26.67 & 61.67 & 11.67 \\
\hline $\mathrm{P} 40$ & Existe um documento formal de como você deve desenvolver a tarefa encomendada? & 57 & 3 & & 95.00 & 5.00 & \\
\hline P41 & Você compreende esse documento? & 53 & 7 & & 88.33 & 11.67 & \\
\hline
\end{tabular}




\section{CONSIDERAÇÕES FINAIS}

A análise estatística dos dados coletados por meio da aplicação da entrevista na mina Condestable permite inferir que as características pessoais dos trabalhadores são similares às das vítimas por acidentes fatais em 2007. As estatísticas de acidentes da mina mostram ainda que os acidentes por queda de rochas constituem o principal tipo de acidente de trabalho, mostrando a mesma tendência que a do cenário nacional, especialmente quando se tem como referência o ano de 2007. A Tabela 2 ainda mostra os resultados da entrevista desenvolvida, permitindo inferir que a empresa e os trabalhadores têm mostrado interesse em desenvolver suas operações e tarefas, respectivamente, de forma cada vez mais segura.

\section{REFERÊNCIAS BIBLIOGRÁFICAS}

CONDESTABLE. Estadística anual. Compañía Minera Condestable, 2010. Archivo electrónico.

LLANQUE, M. O.; NAVARRO, T. V. Explotación subterránea - Métodos e casos prácticos. Puno - Perú: Universidad Nacional del Altiplano, 1999. 253 p.

PERU. Ministério de Energia y Minas del Peru. Atlas minero 2008. Lima, 2008. 85 p.

QUISPE, L. J. Aplicación de taladros largos en la mina Condestable S.A.. Trabajo de conclusión (Graduación) - Departamento de Ingeniería de Minas. Universidad Nacional San Antonio Abad del Cusco. Peru, 2008. 114 p. 